\title{
ELEVATED-TEMPERATURE FRACTURE TOUGHNESS AND \\ FATIGUE TESTING OF STEELS FOR GEOTHERMAL APPLICATIONS
}

\section{ANNUAL PROGRESS REPORT \\ DO NOT MICROFILM COVER}

by
R. A. Cutler
E. C. Gnodman
R. V. Guest
R. R. Hendrickson
W. C. Lestie

Submitted to:

Brookhaven National Laboratory Upton, Long Is I and, New York 11973

Attention: Dr. Daniel Van Rooyen

DOE Contract No. EY-76-C-02-0016

TR 80-87

November 1980

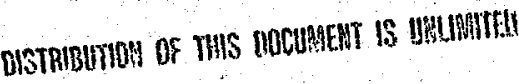
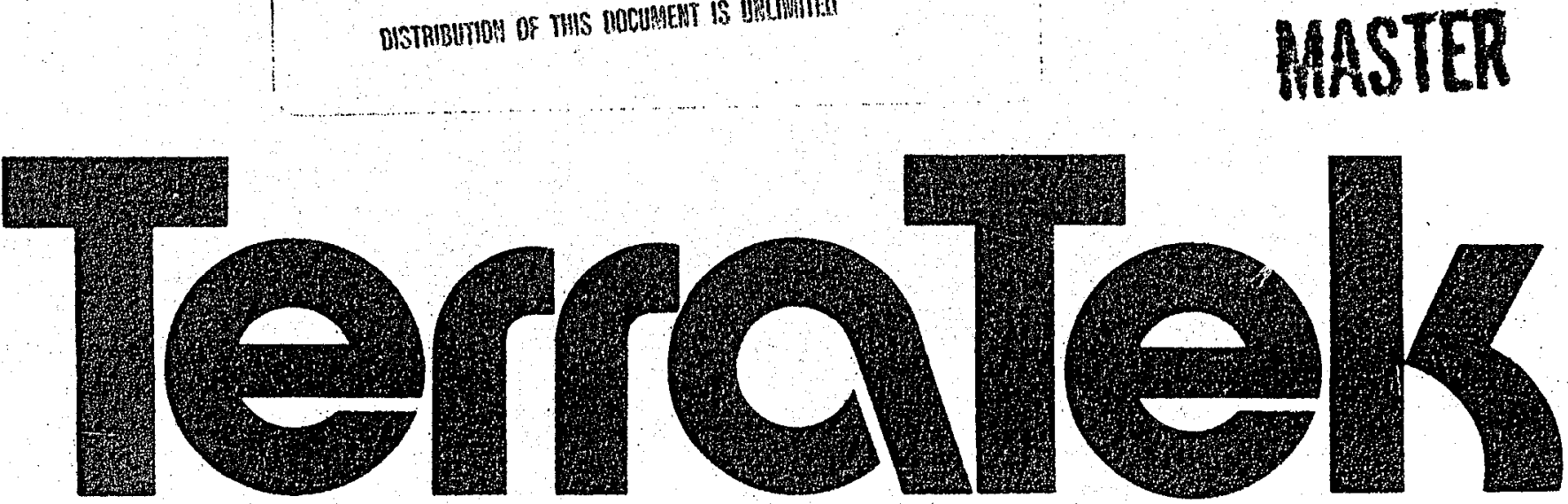


\section{DISCLAIMER}

This report was prepared as an account of work sponsored by an agency of the United States Government. Neither the United States Government nor any agency Thereof, nor any of their employees, makes any warranty, express or implied, or assumes any legal liability or responsibility for the accuracy, completeness, or usefulness of any information, apparatus, product, or process disclosed, or represents that its use would not infringe privately owned rights. Reference herein to any specific commercial product, process, or service by trade name, trademark, manufacturer, or otherwise does not necessarily constitute or imply its endorsement, recommendation, or favoring by the United States Government or any agency thereof. The views and opinions of authors expressed herein do not necessarily state or reflect those of the United States Government or any agency thereof. 


\section{DISCLAIMER}

Portions of this document may be illegible in electronic image products. Images are produced from the best available original document. 


\section{DOE/Ch / OOO16-T2}

\section{ELEVATED-TEMPERATURE FRACTURE TOUGHNESS AND \\ FATIGUE TESTING OF STEELS FOR GEOTHERMAL APPLICATIONS}

\author{
ANNUAL PROGRESS REPORT
}

by

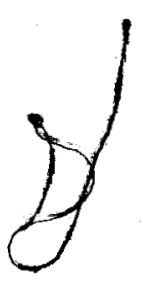

R. A. Cutler

E. C. Goodman

R. V. Guest

R. R. Hendrickson

W. C. Leslie
Submitted to:

Brookhaven National Laboratory Upton, Long Is land, New York 11973

Attention: Dr. Daniel Van Rooyen

DOE Contract No. EY-76-C-02-0016

Submitted by:

Terra Tek, Inc. University Research Park 420 Wakara Way Salt Lake City, Utah 84108
DOE/CH/00016--T2

DE83 013874

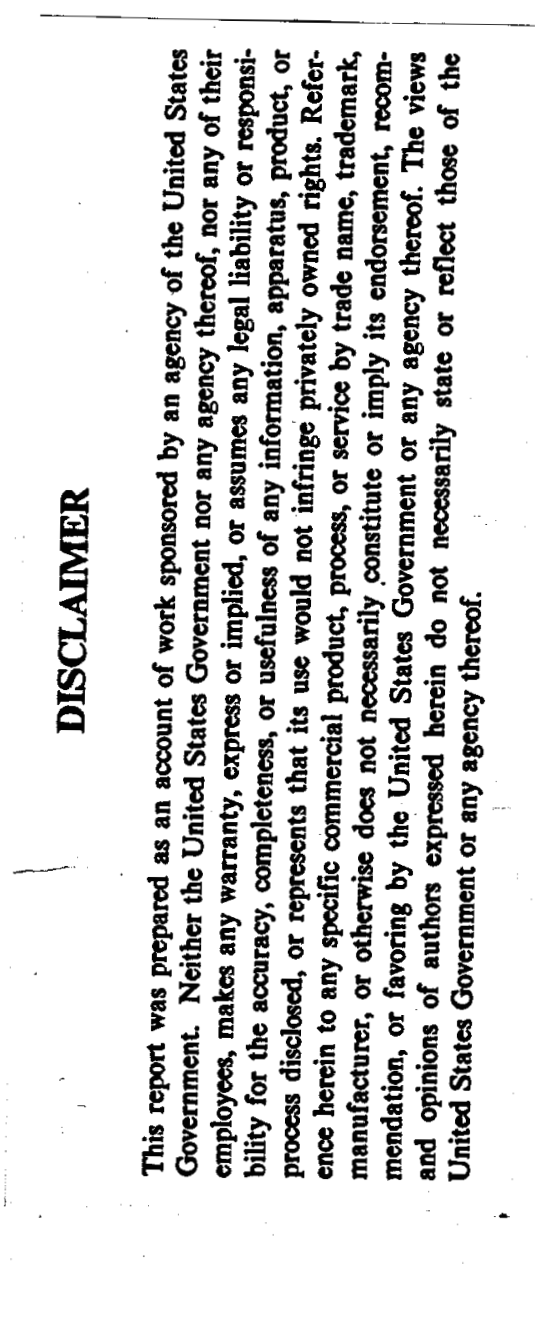

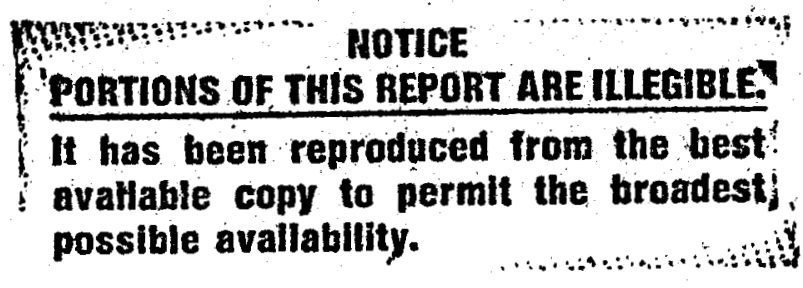

TR 80-87

November 1980 


\section{ABSTRACT}

Conventional drill bit steels exhibit increased wear and decreased toughness when run at elevated temperatures in geothermal wells. Bits are therefore run at lower speeds and lighter loads, resulting in lower penetration rates for geothermal wells than for conventional rock drilling.

Carpenter EX-00053, Timken CBS 600, Timken CBS 1000M and Vasco X-2M, steels with improved hot hardness (improved wear resistance), were tested in conjunction with the steels used for cones (AISI 4820 and 9315) and lugs (AISI 8620 and 9315 ) in conventional roller cone rock bits. Shortrod fracture toughness measurements were made on each of these steels between room temperature and $400^{\circ} \mathrm{C}$. Fatigue crack resistance was determined at $300^{\circ} \mathrm{C}$ for high-temperature steels and at room temperature for conventional steels. Scanning electron microscopy analyses of the fractured short-rod specimens were correlated with observed crack behavior from the test records. Test results are discussed, recommendations made for further testing and preliminary steel selections made for improved geothermal bits. 
Abstract ...........................

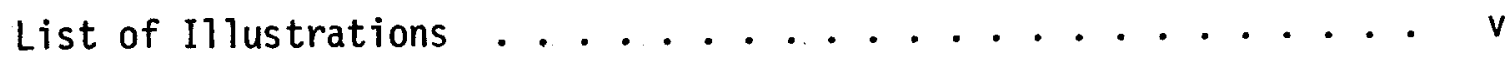

List of Tables ........................... vi

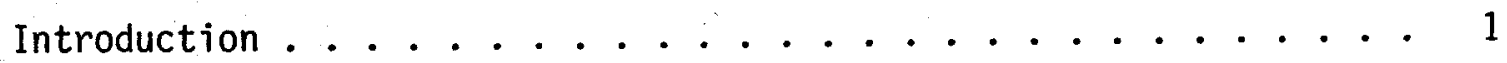

Current Geothermal Drilling Practice and Experience...... 1

Previous Terra Tek/DOE Geothermal Drill Bit Program Results ... 2

Current Research ................... 11

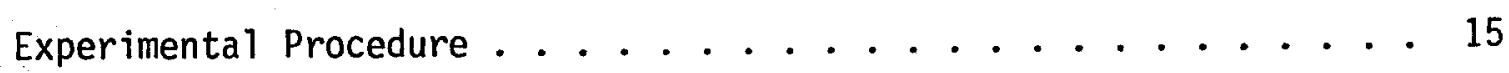

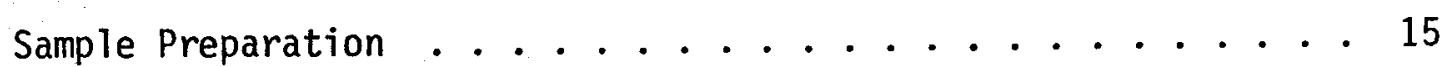

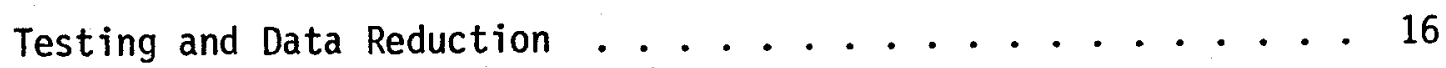

Fatigue Crack Resistance Measurements .......... 24

Results and Discussion.................. 27

Steet Characterization ................. 27

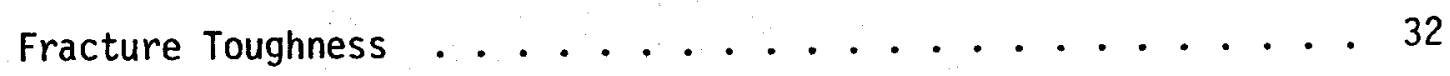

Fatigue Crack Resistance Measurements .......... 41

Conclusions ............................ 53

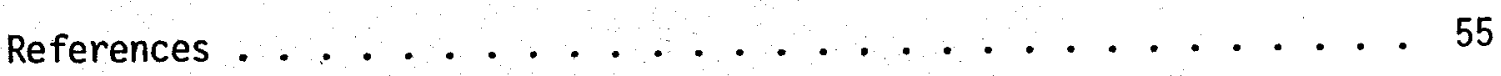

Acknowledgments ........................... 57

Appendix $A$ - Heat Treatment and $\mathrm{K}_{\text {Ic }}$ Data ......... 59

Appendix B - SEM Micrographs .............. 65

Appendix C - Program Participants ......... 83 



\section{LIST OF ILLUSTRATIONS}

Figure

Description

Page

1

2

3

4

5

6

7

8

9

10

11

12

13

14

15

16

17

18

19

The Drilling Research Laboratory . . . . . . . . 3

Geothermal wellbore simulator .......... 4

The geothermal air-drilling test facility . . . . . 4

Brittle failure of $\mathrm{H}-13$ lug . . . . . . . . 5

Materials selected for the third-generation drill bits . . 7

Fracture toughness for the roller bearing steels . . . . 8

Fracture toughness at temperature for CBS 600 lug steel at a core hardness level of $R_{C} 35 \ldots \ldots 8$

Hardness versus temperature for bit lug materials . . . 9

Wear data for bits tested at Geysers . . . . . . . . 10

Effect of temperature on hardness of conventional and experimental steels.............. 13

Short-rod specimen geometry . . . . . . . . . 17

Fracjack loading device with specimen installed over grips ................ . . 19

Fracjack located in tensile testing machine . . . . . 19

Installation of a specimen on the fracjack grips . . . . 20

Installation of the temperature control chamber over a short-rod .................... 20

Tensile testing machine, control panel and temperature controller used for short-rod fracture toughness and fatigue measurements ............ 21

Load versus LPO test record for a steel sample with minimal plasticity ............... 22

Fracture toughness as a function of temperature for 4820 (heat treatment A) ............... 33

Effect of temperature on the toughness of 8620 (heat treatment B) 
Fracture toughness of 9315 as a function of temperature

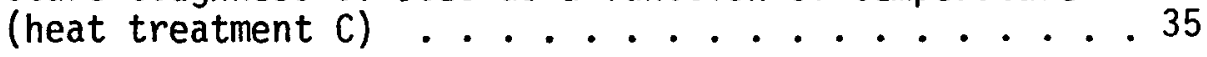

21 Effect of temperature on the toughness of CBS $600 \ldots 35$

22 Temperature dependence of toughness for CBS 1000M . . . 37

23 Effect of test temperature on fracture toughness of EX-00053 (heat treatment $L$ ) ......... 39

24 Effect of temperature on the toughness of $X-2 M$ (heat

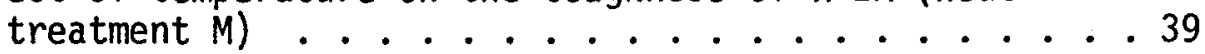

25 Toughness comparison of conventional and high wear resistant steets ................. 41

26 Crack growth rate as a function of stress intensity factor for AISI $4820 \ldots . . . . . . .43$

27 Crack growth rate as a function of stress intensity factor for AISI $8620 \ldots . . . . . . .45$

28 Crack growth rate as a function of stress intensity factor for AISI 9315 ............ 45

29 Crack growth rate as a function of stress intensity factor for CBS $600 \ldots . . . . . . .47$

30 Crack growth rate as a function of stress intensity factor for CBS 1000M ......... . . 47

31 Crack growth rate as a function of stress intensity factor for EX-00053 ............ 48

32 Crack growth rate as a function of stress intensity

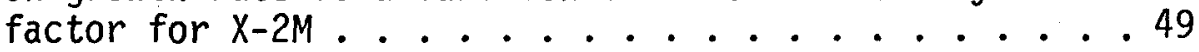

33 Crack growth rate as a function of stress intensity factor for all steels tested ......... 49

B1- SEM micrographs ............... . . . . . . . 


\section{LIST OF TABLES}

$\underline{\text { Table }}$

Description

Page

1

Wear Measurements for Conventional and MK-II Experimental Bits Tested at $316^{\circ} \mathrm{C}$ in Geothermal Wellbore Simulator ................. 5

Candidate High-Temperature Alloy Steels ........ 11

3

Nominal Steel Compositions ............ 13

$4 \quad$ Ladle and Check Analyses of Steels . . . . . . . . . 17

5

Chemical Analysis (Percent by Weight) . . . . . . . 28

6

Characterization of Steels . . . . . . . . . 28

7

Fracture Mode Based on SEM Micrographs . . . . . . . 31

8

Fatigue Crack Resistance Results . . . . . . . . 43

A1 Brookhaven Geothermal Materials Contract Fracture

Toughness Data ............. 61 


\section{INTRODUCTION}

\section{Current Geothermal Drilling Practice and Experience}

Geothermal drilling is done almost exclusively with rolling cutter bits, 3-point stabilizers, and other conventional drilling equipment developed for oil and gas recovery, and for mining applications. Unfortunately these components have not been optimized for higher temperature operation, and deliver only about one-fifth of their normal life (footage) when used in some geothermal applications ${ }^{1}$. Performance in geothermal wells is further reduced since lighter bit loads must be used to prevent cataclysmic bit failures, and to avoid unwanted deviations caused by worn stabilizers. The resulting lower penetration rate (onethird to one-half of normal in many cases) is of much greater economic importance than the cost of the bit due to the high daily cost of the drill rig. A bit capable of doubling the penetration rate is worth eight times the cost of the conventional bit ${ }^{2}$. The time lost in "tripping" to replace the bit and stabilizers incurs high rig costs which exceed the cost of the replaceables by two to four times. The overall cost per foot can be reduced by 25 percent or more by the development of bits and stabilizers having service lives which are equivalent to those of conventional bits and stabilizers in nongeothermal use.

The most severe geothermal drilling environments are those involving air drilling into hot, hard, abrasive formations. Additional factors such as swelling, inclined bedding, and fractures can further slow the drilling process. Air drilling is necessary in highly fractured, subhydrostatic 
reservoirs to avoid "lost circulation", and to avoid permanent quenching of steam vents. The air provides very little cooling of the bit and stabilizers because (a) it has usually been heated to the formation temperature by the time it arrives at the bottom, and (b) its specific heat is much lower than that of mud or water. Friction can heat localized areas of the bearings to temperatures far in excess of the formation temperature. Surface corrosion and stress corrosion cracking (hydrogen embrittlement) are generally insignificant in air-drilled geothermal wells. The drill bit is only exposed to steam as it passes through a steam entry point, or when tripping, since the drilling air provides a constant purging action. The $\mathrm{H}_{2} \mathrm{~S}$ embrittlement problem usually decreases with increased temperature, evidenced by the fact that brittle failure of drill bits at the Geysers has been almost non-existent ${ }^{3}$.

\section{Previous Terra Tek/DOE Geothermal Drill Bit Program Results}

New steels and tungsten carbides for geothermal roller cone bits were evaluated by a combination of full-scale laboratory drilling tests under simulated geothermal conditions, field geothermal drilling, and material properties tests ${ }^{3}$. Three generations of bits were built and tested; the third-generation bits concluded successful field tests at the Geysers in September, 1978. These prototypes exhibited an improvement of 40 percent in bit life. The lack of suitable stabilizers precluded evaluation of higher bit weights, which would have demonstrated the full potential of the new bits.

The Drilling Research Laboratory, shown in Figure 1, was utilized for evaluation of all three generations of bits. The first two generations 
TABLE 1

Wear Measurements for Conventional and MK-II Experimental Bits Tested at $316^{\circ} \mathrm{C}$ in Geothermal Wellbore Simulator

\begin{tabular}{|l|c|c|c|}
\cline { 2 - 4 } \multicolumn{1}{c|}{} & $\begin{array}{c}\text { CONVENTIONAL } \\
\text { BIT "A" }\end{array}$ & $\begin{array}{c}\text { MK-II BIT } \\
\text { "G" }\end{array}$ & $\begin{array}{c}\text { MK-II BIT } \\
\text { "HO" }\end{array}$ \\
\hline RUN-TIME, MINUTES & 20,000 & 25,000 & 20,000 \\
LUG MEARI & $150-180^{3}$ & 120 & 100 \\
Friction Pin & & & \\
Bali Race & 0.012 & 0.002 & 0.000 \\
Roller Race, IN2 & 0.030 & 0.016 & 0.040 \\
Roller Race, OUT2 & 0.044 & 0.004 & 0.007 \\
CONE WEARI & 0.060 & 0.003 & 0.003 \\
Friction Pin & & & \\
Ball Race & 0.001 & 0.001 & 0.000 \\
Roller Race, IN2 & 0.018 & 0.000 & 0.004 \\
Roller Race, 0UT2 & 0.025 & 0.006 & 0.007 \\
& 0.033 & 0.005 & 0.015 \\
\hline
\end{tabular}

1. All wear measurements in thches; values shown are maximums.

2. Two measurements were made of tapered wear on both cones and bits. IN and OUT measurements are described in Figure 9 of Terra Tek Report TR 78-41.

3. Bit "A" ran for five hours and 16 minutes, but cones locked between 150180 minutes into test, at which time wear on bearing surfaces would have stopped.

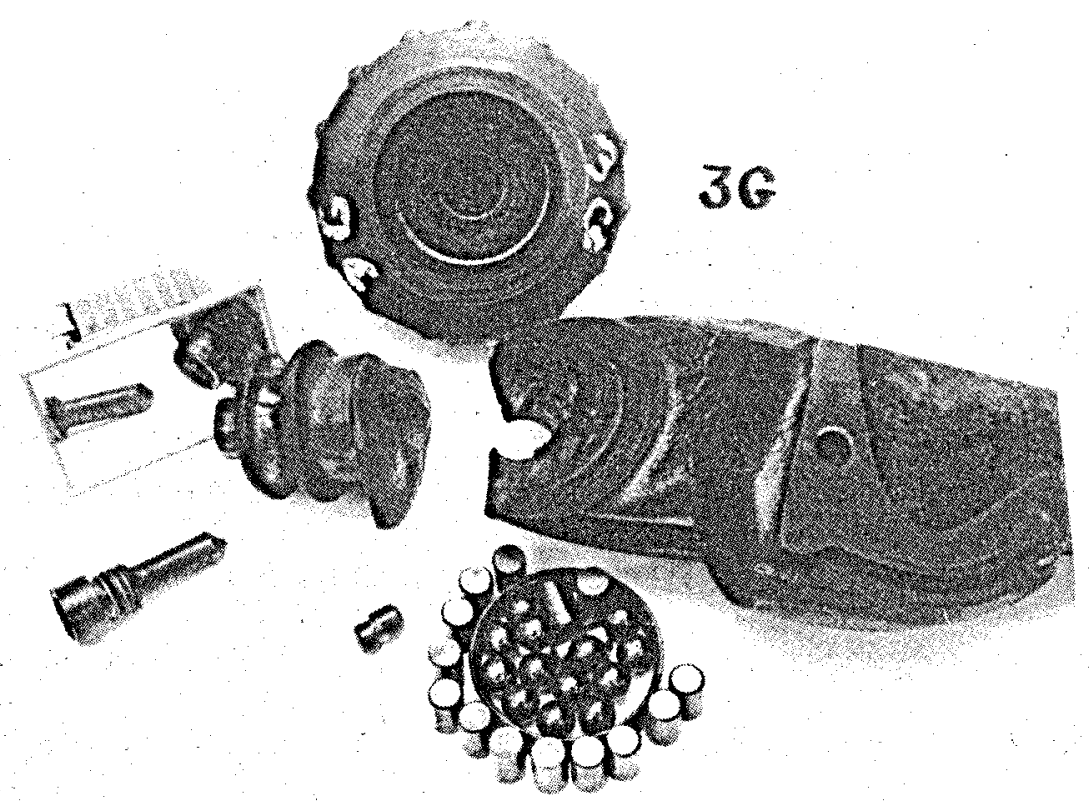

Figure 4. Brittle failure of $\mathrm{H}-13$ lug. 
Steels were sought for the third generation bits which could maintain high levels of fracture toughness in addition to maintaining high hardness in the bearing races and high tensile strength to prevent rupture. Baseline fracture toughness tests on AISI 8620 (conventional lugs) and AISI 4820 (conventional cones) indicated toughness values of $135 \mathrm{MPa} \sqrt{\mathrm{m}}$ (123 $\mathrm{ksi} \sqrt{\mathrm{in}}$ * and $90 \mathrm{MPa} \sqrt{\mathrm{m}}(82 \mathrm{ksi} \sqrt{\mathrm{in}})$ respectively. Steels were sought for the lugs and cones which could meet these fracture toughness requirements, with the best attainable race hardness values. The materials selections are shown in Figure 5. Laboratory determinations of fracture toughness for M50 (rollers), shown in Figure 6, illustrate how some hardness was sacrificed to maximize fracture toughness. It is important to realize that the sacrifice of hardness does not always enhance the toughness of steels. Figure 7 plots fracture toughness as a function of temperature for the CBS 600 lug steel; these data were obtained using the "short-rod" technique with 2-inch diameter by 3 -inch long samples. It should be noted that toughness decreases with temperature for this steel, thus illustrating the importance of elevated-temperature toughness testing: all previously tested steels exhibited increasing toughness with temperature. Figure 8 shows the desirable hot-hardness characteristics of CBS 600 , as compared to AISI 8620 .

Six of the third-generation bits were run at the Geysers by Union Geothermal; the prototypes were alternated with the Reed Y73-JA conventional bits which are geometrically identical. The bits drilled typical Geysers ("Franciscan") graywacke sandstone; the air entering the bits was

* The 1-inch diameter sample used for the AISI 8620 was too small for a valid $\mathrm{K}_{\text {Ic }}$ measurement, even with the "short-rot" method employed; the $135 \mathrm{MPa} \sqrt{\mathrm{m}}$ figure is accurate to within \pm 15 percent. 


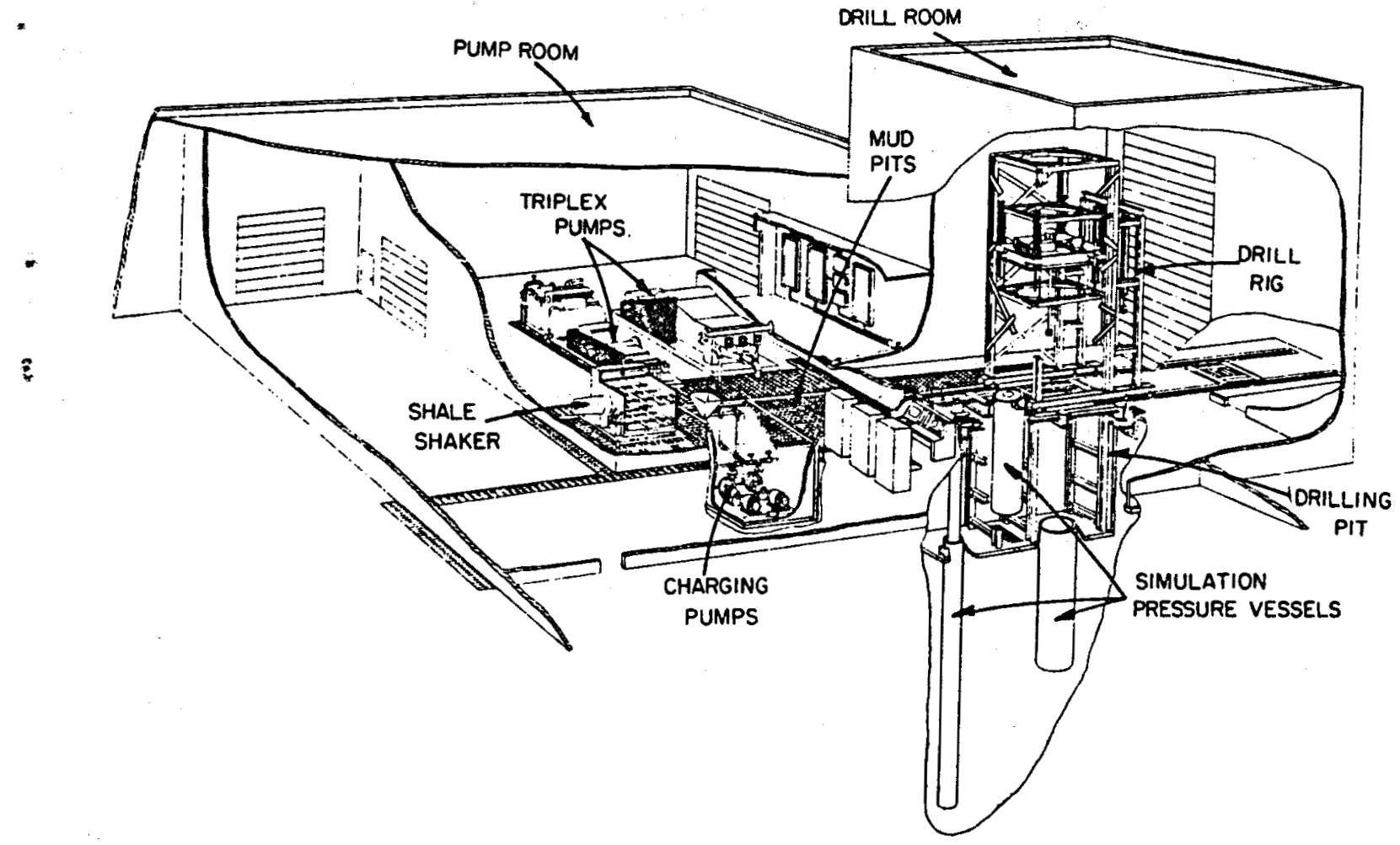

Figure 1. The Drilling Research Laboratory.

were run in the Geothermal Wellbore Simulator (Figure 2), while two of the third-generation bits were run in the Geothermal Air-Drilling Test Facility (Figure 3) prior to the field tests. A total of six third-generation bits were evaluated at the Geysers by Union Geothermal Division of Union $0 i 1$ Company.

The first two generations of bits were fabricated by Reed Tool Company from tool steels which were known to retain hardness at temperatures to $400^{\circ} \mathrm{C}$, such as $H-13$ (Tugs), Vasco MA and Vasco X2 (cones), and M50 (bearings). Back-to-back drilling tests with conventional bits in the Geothermal Wellbore Simulator at $316^{\circ} \mathrm{C}$ revealed an approximate ten-to-one reduction in I bearing wear (Table 1). While these results clearly indicated the importance of retaining bearing race hardness at temperature, brittle failures of both cones and lugs were experienced as shown in Figure 4. 


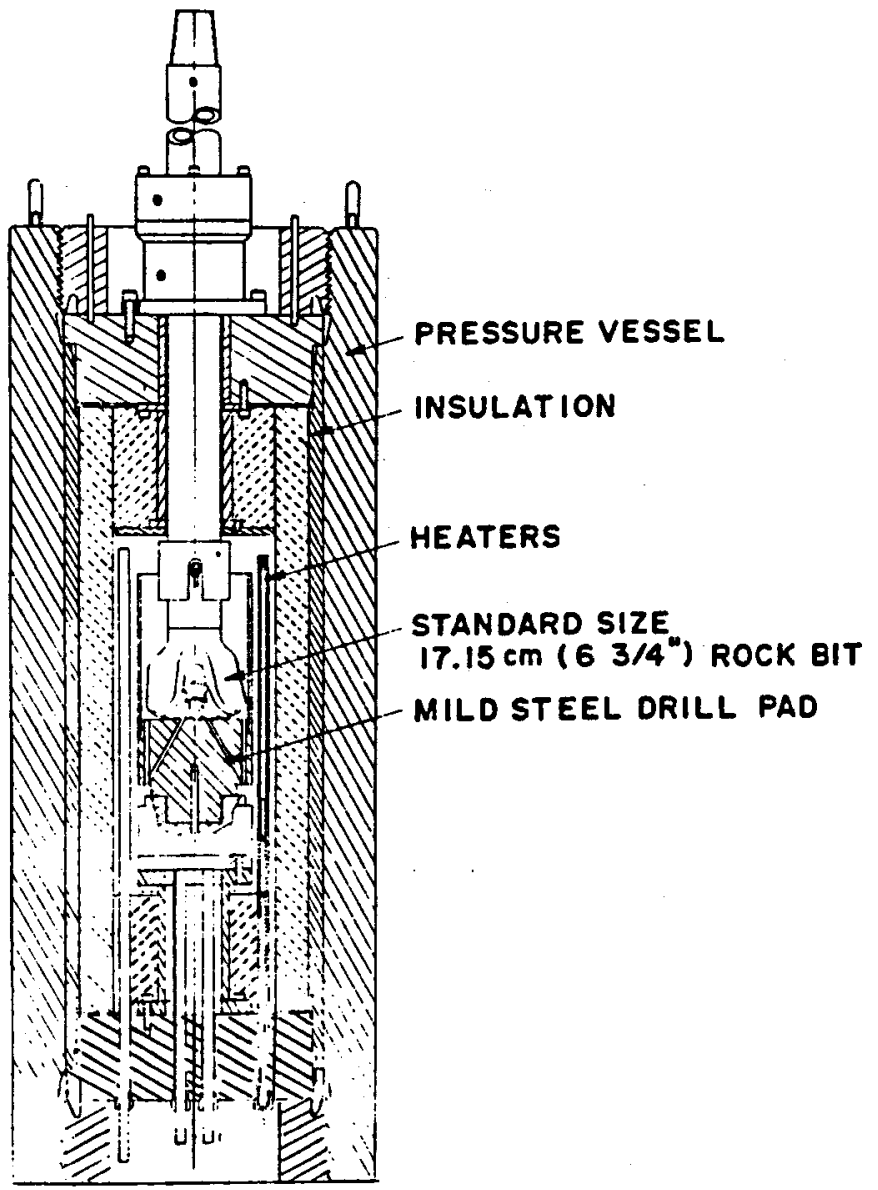

Figure 2. Geothermal wellbore simulator.

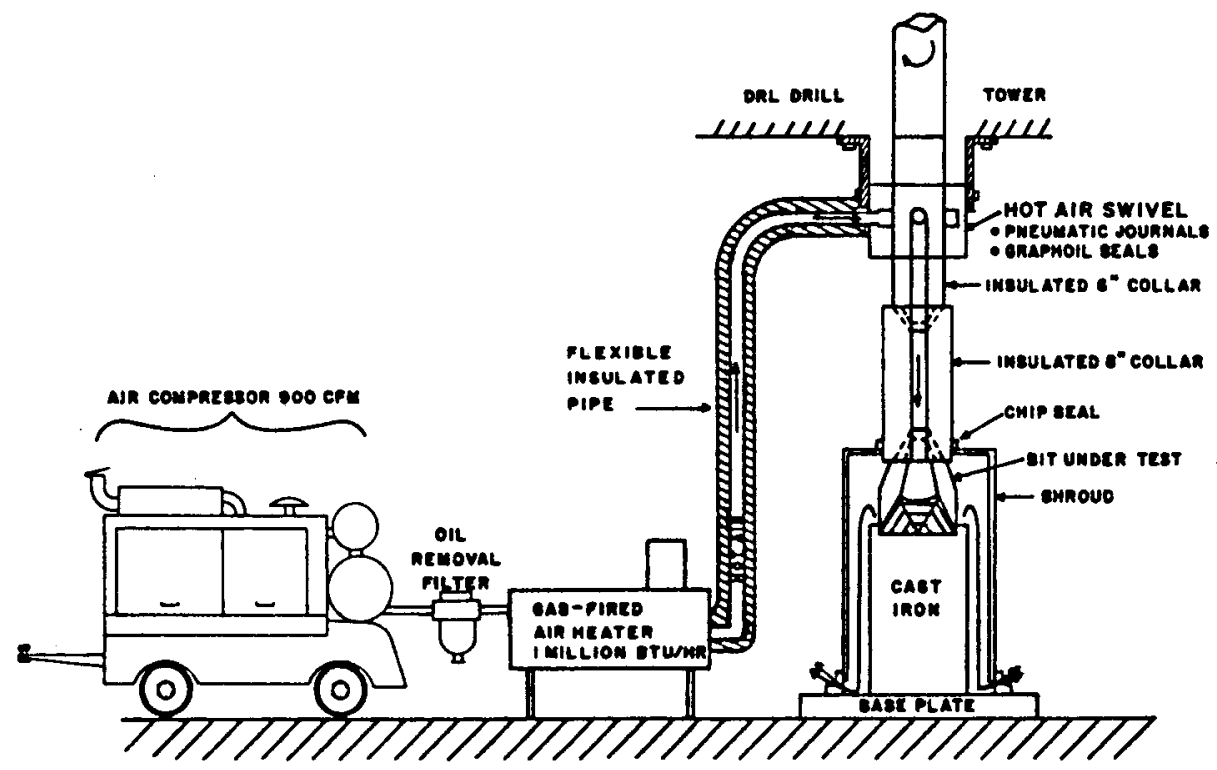

Figure 3. The geothermal air-drilling test facility. 

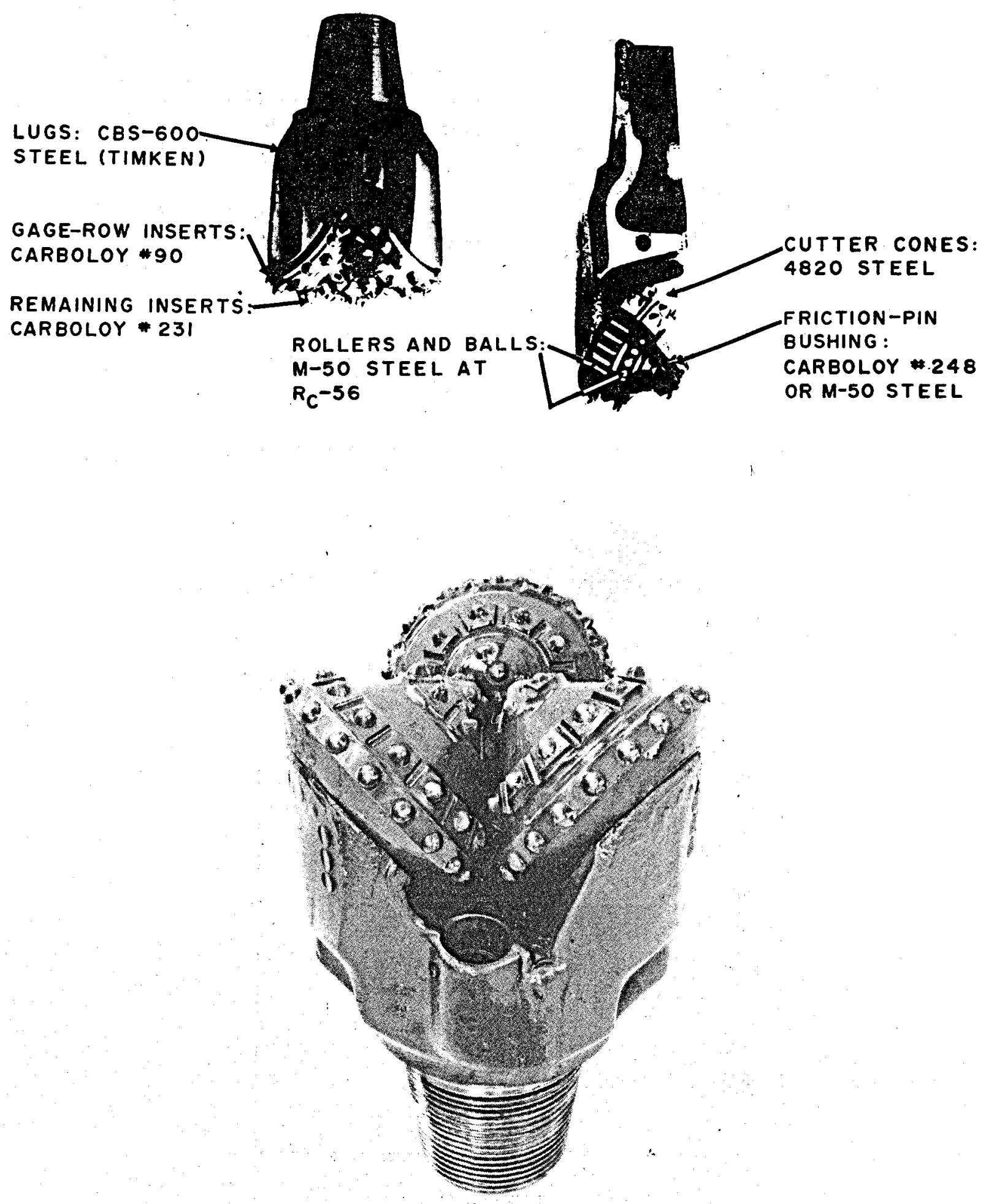

I.

Figure 1. Materials selected for the third-generation drill bits. 


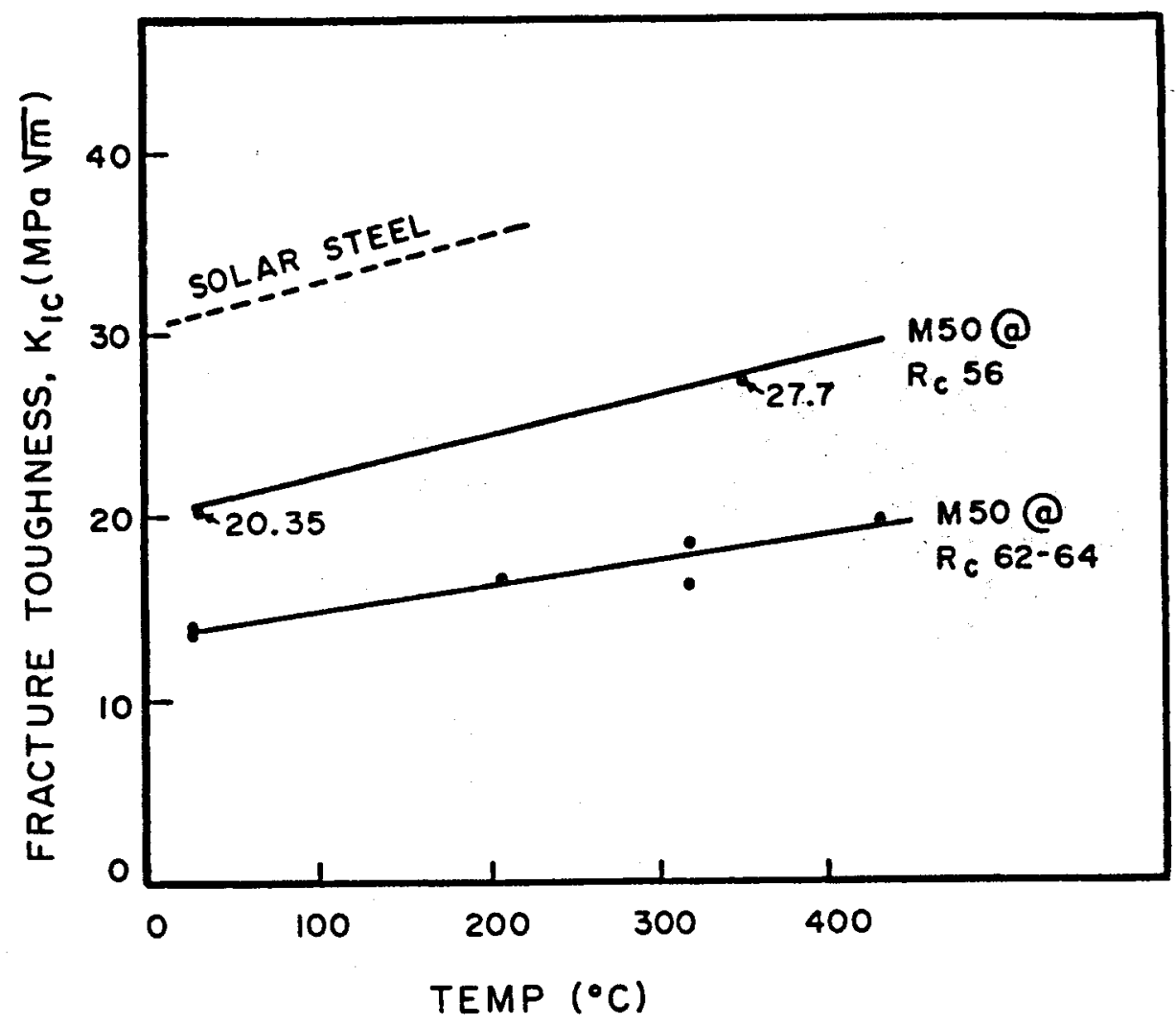

Figure 6. Fracture toughness for the roller bearing steels.

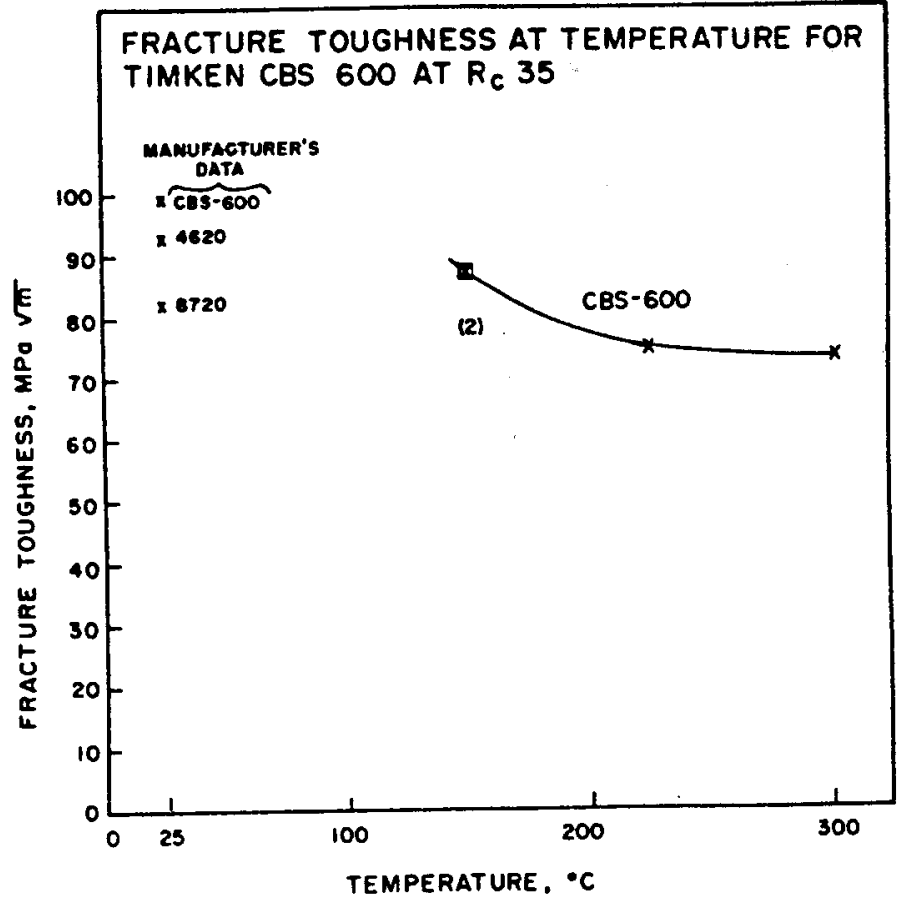

Figure 7. Fracture toughness at temperature for CBS 600 lug steel at a core hardness level of $R_{c} 35$. 


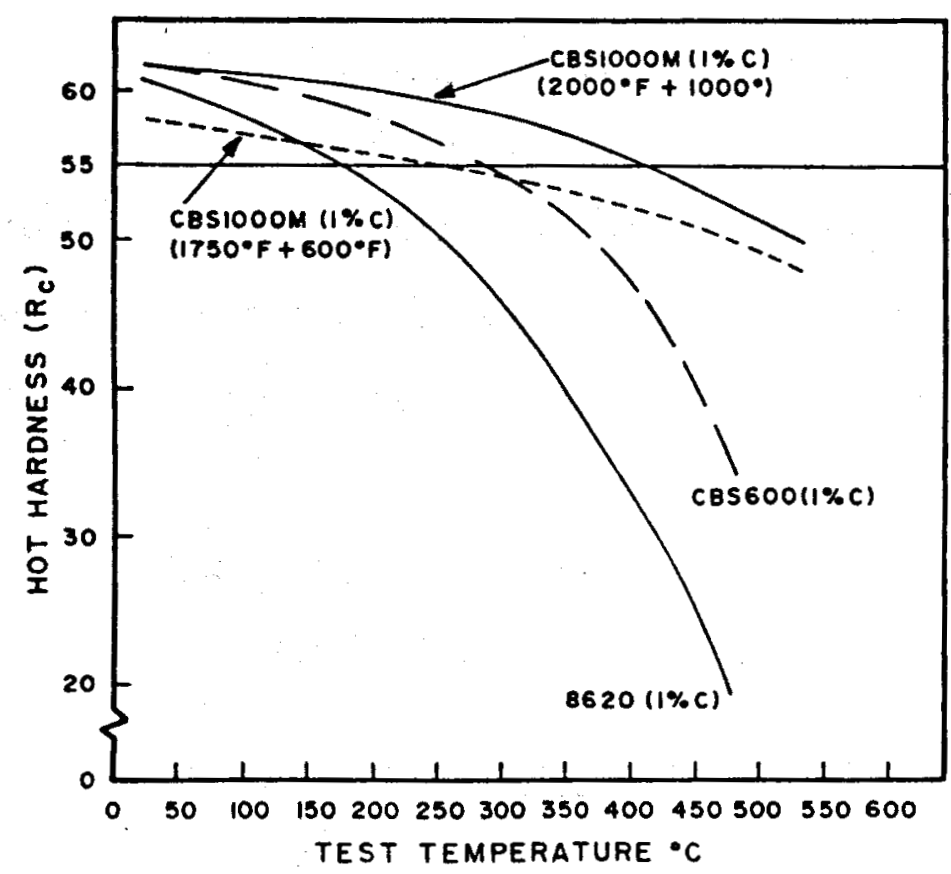

Figure 8. Hardness versus temperature for bit lug materials (Timken Corporation).

at the formation temperature, i.e., about $240^{\circ} \mathrm{C}$. A detailed post-mortem wear analysis (Figure 9) of the experimental and conventional bits revealed the superior performance of the third-generation bits.

The following conclusions and observations on bearing wear were drawn from these drilling tests ${ }^{3}$ :

- The use of CBS 600 reduced lug wear by about $2 \frac{1}{2}$ to 1 in the ball and roller races, and on the pilot pins of the bits utilizing M50 bushings. Lug wear, although greatly improved, needs to be reduced further. Microhardness traces on sections of CBS-600 lugs indicated that surface temperatures exceeded $400^{\circ} \mathrm{C}$ on the roller and ball races, and $600^{\circ} \mathrm{C}$ under the Stellite on the end of the pilot pin. Deformation of the pilot pins was noted on the experimental bits but to a lesser extent than on the Y73JA's. 
- CBS 600 should also be used for the cones.

- The M50 rollers experienced very minimal wear.

- The excessive ball wear was due to the design of the ball retainer plug; a definitive test of the M50 balls is still required. Good performance is expected, based on the low wear experienced by the M50 rollers.

- Overall wear in the pilot bearing system ("friction pin area") is excessive and should be reduced by a factor of three.

WEAR DATA FOR BITS TESTED AT GEYSERS.

CALIFORNIA DURING SUMMER OF 1978

\section{ROLLER BEARING AREA}

A

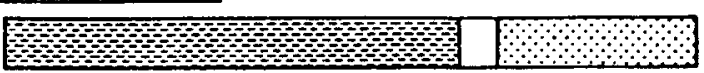

B

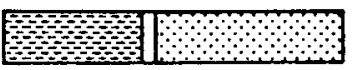

c

BALL BEARING AREA

$\Delta$

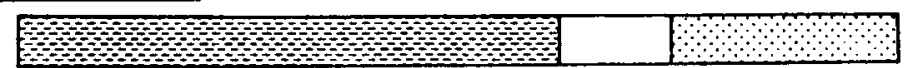

B

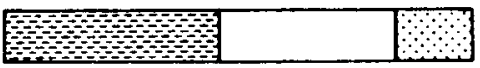

c

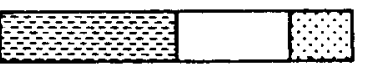

FRICTION PIN AREA

A

B

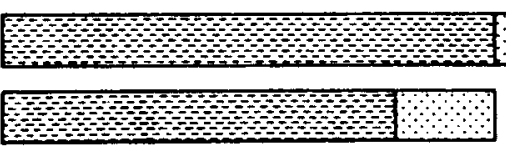

C

A

KEY:

A) STANDARD REED Y73-JA BIT

B) TERRA TEK EXPERIMENTAL BIT WITH TUNGSTEN-CARBIDE BUSHINGS

C) TERRA TEK EXPERIMENTAL BIT WITH M-50 BUSHINGS

LUG WEAR

BEARING WEAR

CONE WEAR

Figure 9. Wear data for bits tested at Geysers. 
Current Research

The previous Terra Tek/DOE work greatly enhanced the understanding of the relationships between laboratory materials property tests and field drilling performance in the geothermal environment. Since conventional steels fail by excessive wear rather than by brittle fracture in the field ${ }^{3}$,

* it was determined that steels which have high hot hardness and hence superior resistance to wear at elevated temperatures should be the prime candidates for improved geothermal lugs and cones. The brittle fracture of the cones and lugs of the MK-II experimental bits, however, indicate the need for fracture toughness and fatigue crack resistance in the experimental steels at levels comparable to those of the conventional steels. Three new candidate steels are listed in Table 2 along with CBS-600, which requires further evaluation.

TABLE 2

Candidate High-Temperature Alloy Steels

\begin{tabular}{|l|c|c|}
\hline MANUFACTURER & ALLOY & RECOMMENDED BY \\
\hline Carpenter & EX-00053 & Smith Tool Company \\
Teledyne-Vasco & X2 Modified & Terra Tek/DOE Program \\
Timken & CBS $1000 M$ & Timken Research Center \\
Timken & CBS 600 & Terra Tek/DOE Program \\
\hline
\end{tabular}


All of these steels are either in use, or under consideration, for applications where high-strength, high-temperature carburizing steels are required. These include: helicopter main drive gears, speed reducers for turboprops, jet helicopters, and gas-turbine truck engines, as well as afterburner and thrust reverser mechanisms for military aircraft. Nominal composition for the high-temperature steels and for conventional steels are given in Table 3. Hardness of both the carburized case and core of al1 of these steels except AISI 4820 are displayed in Figure 10 as a function of temperature. The hardness of 8620 and 9315 declines rapidly with increasing temperature in both the case and core as opposed to the excellent retention of hardness in the experimental steels. Although manufacturer's hot-hardness data were not available for 4820 , it is expected to behave similarly to 9315 . CBS 1000M appears to have the highest hot-hardness.

The objectives of the present research are therefore to characterize the fracture toughness and fatigue behavior of steels presently used in rotary drill bits and reaming stabilizers and to identify high wearresistance steels with equivalent toughness and fatigue crack resistance at temperatures to $400^{\circ} \mathrm{C}$. It is felt that wear-resistant steels with fracture toughness values at $200^{\circ} \mathrm{C}-400^{\circ} \mathrm{C}$ between $90 \mathrm{MPa} \sqrt{\mathrm{m}}(82 \mathrm{ksi} \sqrt{\mathrm{in}}$ ) and $135 \mathrm{MPa} \sqrt{\mathrm{m}}$ (123 ksi $\sqrt{\mathrm{in}}$ ) would have sufficient toughness to maintain high penetration rates in geothermal wells. The 90-135 $\mathrm{MPa} \sqrt{\mathrm{m}}$ range was determined from a limited data bank of fracture toughness data for 4820 (cones) and 8620 (lugs) developed at Terra Tek ${ }^{3}$. The two steels which exhibited brittle failure in the MK-II bits had $K_{I C}$ values between 25 and $65 \mathrm{MPa} \sqrt{\mathrm{m}}$ at temperatures up to $400^{\circ} \mathrm{C}^{4}$. 
TABLE 3

Nominal Steel Compositions

\begin{tabular}{|c|c|c|c|c|c|c|c|c|c|c|c|}
\hline \multirow[b]{2}{*}{ Steel Type } & \multicolumn{11}{|c|}{ Composition ( $\because$ by weight) } \\
\hline & C & $M n$ & $P$ & $S$ & Si & $\mathrm{Cr}$ & $\mathrm{Ni}$ & Mo & V & W & $\mathrm{Cu}$ \\
\hline AISI 4820 & 0.20 & 0.60 & 0.035 & 0.040 & 0.28 & -- & 3.50 & 0.25 & -- & -- & -- \\
\hline AISI 8620 & 0.20 & 0.80 & 0.035 & 0.040 & 0.28 & 0.50 & 0.55 & 0.20 & -- & -- & -- \\
\hline AISI 9315 & 0.15 & 0.55 & 0.025 & 0.025 & 0.28 & 1.20 & 3.25 & 0.12 & -- & -- & -- \\
\hline CBS 600 & 0.20 & 0.55 & -- & -- & 1.05 & 1.45 & -- & 1.00 & -- & -- & -- \\
\hline CBS $1000 \mathrm{M}$ & 0.13 & 0.50 & -- & - & 0.50 & 1.05 & 3.00 & 4.50 & -- & - & - \\
\hline EX-00053 & 0.10 & 0.35 & -- & -- & 1.00 & 1.00 & 2.00 & 3.25 & 0.10 & - & 2.00 \\
\hline Vasco X2M & 0.13 & 0.25 & -- & $=-$ & 1.00 & 5.20 & 0.06 & 1.30 & 0.40 & 1.35 & -- \\
\hline
\end{tabular}

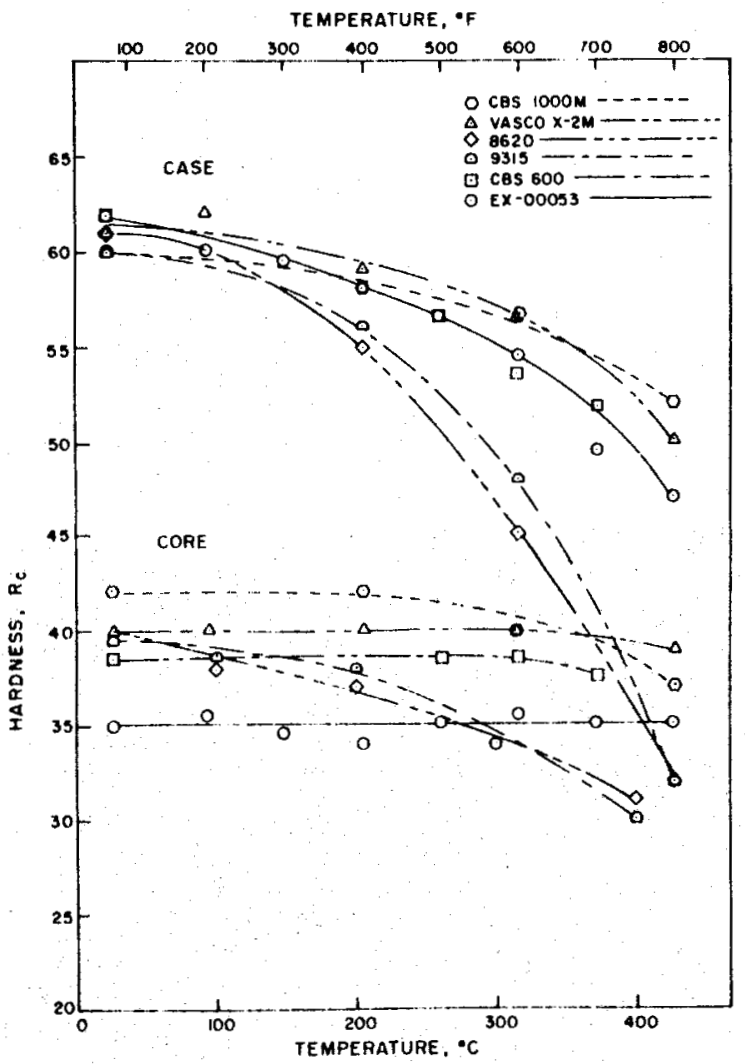

Figure 10. Effect of temperature on hardness of conventional and experimental steels. 


\section{EXPERIMENTAL PROCEDURE}

\section{Sample Preparation}

AISI 4820: Test blanks $50.8 \mathrm{~mm}$ diameter by $76.2 \mathrm{~mm}$ long were machined from a forged and annealed rod $1.8 \mathrm{~m}$ in length. The steel was of aircraft quality and had been vacuum melted. The long axes of the blanks were parallel to the axis of forging.

AISI 8620: Cylinders $50.8 \mathrm{~mm}$ diameter by $76.2 \mathrm{~mm}$ long were made from an air-melted, hot-rolled rod $57.2 \mathrm{~mm}$ diameter by $1.8 \mathrm{~m}$ in length. The long axes of the specimens were parallel to the rolling direction.

AISI 9315: Specimens $25.4 \mathrm{~mm}$ diameter by $38.1 \mathrm{~mm}$ long were cut from aircraft-quality, vacuum-arc-remelted steel. The hot-rolling direction was parallel to the long axes of the cylinders.

CBS 600: Cylindrical rods $50.8 \mathrm{~mm}$ diameter by $76.2 \mathrm{~mm}$ long were machined from vacuum-arc-remelted, hot-rolled stock. The long axes of the specimens were parallel to the rolling direction. Test blanks 25.4 $\mathrm{mm}$ diameter by $38.1 \mathrm{~mm}$ long were made from a forged bar which was quartered before machining the diameter of the cylinders. The long axes of the specimens were again parallel to the axis of forging.

CBS 1000M: Test blanks $50.8 \mathrm{~mm}$ diameter by $76.2 \mathrm{~mm}$ long were turned from a hot-rolled $76.2 \mathrm{~mm}$ diameter rod. The steel had been vacuum induction melted and vacuum-arc-remelted (VIMVAR) and specimen axes were parallel to the rolling direction. $25.4 \mathrm{~mm}$ diameter by $38.1 \mathrm{~mm}$ long cylinders were made from a separate heat in an identical manner except that the steel was rolled to the smaller diameter. 
EX-00053: A rough forged rod approximately $60 \mathrm{~mm}$ in diameter was machined into cylinders $50.8 \mathrm{~mm}$ diameter by $76.2 \mathrm{~mm}$ long. The steel was VIMVAR and specimen axes were parallel to the axis of forging.

X-2M: Vacuum-melted, hot-rolled rods were used to make cylinders $50.8 \mathrm{~mm}$ diameter by $76.2 \mathrm{~mm}$ long. The cylinder axes were parallel to the rolling direction.

Ladle analyses of 4820,8620 , EX-00053 and X-2M, as well as the chemical composition of the $25.4 \mathrm{~mm}$ cylinders supplied by the Timken company, are listed in Table 4. Detailed heat treatments of each of the steels appear in Appendix A. A grip groove was machined into the end of each specimen as illustrated in Figure 11. Thin slots were then machined longitudinally in the cylinder, leaving a "V"-shaped ligament in the intended crack plane.

\section{Testing and Data Reduction}

Fracture Toughness: The short-rod method ${ }^{5}$ was used to measure the fracture toughness of the steels as a function of temperature. The theory for this novel technique has been developed for materials displaying linear elastic fracture mechanics (LEFM) $^{6}$ and for non-LEFM specimens ${ }^{7}$. Comparisons of the short-rod technique with the standard ASTM E399 method of measuring fracture toughness have shown good agreement ${ }^{8}$, as have different techniques for calibrating the short-rod specimens ${ }^{9,10}$. Although several advantages of the short-rod method have become apparent ${ }^{11}$, the main reason for using the technique to evaluate drill bit materials is that specimen diameters similar to the through-section thickness of cones or lugs can be 
TABLE 4

Ladle and Check Analyses of Steels

\begin{tabular}{|c|c|c|c|c|c|c|c|c|c|c|c|c|}
\hline Steel Type & C & $\mathrm{Mn}$ & $\mathrm{P}$ & $S$ & $\mathrm{Si}$ & $\mathrm{Cr}$ & $\mathrm{Ni}$ & Mo & v & $w$ & $\mathrm{Cu}$ & Al \\
\hline AISI $4820^{1}$ & 0.18 & 0.65 & 0.012 & 0.013 & 0.26 & 0.15 & 3.30 & 0.25 & -- & -- & 0.08 & -- \\
\hline AISI $8620^{1}$ & 0.19 & 0.74 & 0.013 & 0.021 & 0.21 & 0.48 & 0.47 & 0.18 & -- & -- & 0.04 & 0.050 \\
\hline AISI $9315^{2}$ & 0.13 & 0.59 & 0.009 & 0.006 & 0.31 & 1.31 & 3.28 & 0.12 & -- & -- & -- & 0.030 \\
\hline CBS $600^{2}$ & 0.20 & 0.60 & 0.004 & 0.004 & 1.01 & 1.55 & 0.06 & 0.97 & -- & -- & -- & 0.036 \\
\hline CBS $1000 M^{2}$ & 0.13 & 0.54 & 0.008 & 0.007 & 0.38 & 1.01 & 3.05 & 4.47 & 0.39 & -- & -- & 0.035 \\
\hline$E X-00053^{1}$ & 0.103 & 0.33 & 0.007 & 0.006 & 0.95 & 0.99 & 2.03 & 3.32 & 0.11 & -- & 2.06 & -- \\
\hline$x-2 M^{2}$ & 0.14 & 0.20 & 0.014 & 0.003 & 0.98 & 4.80 & -- & 1.33 & 0.45 & 1.34 & -- & -- \\
\hline
\end{tabular}

1 Ladle analysis

2 Chemical composition of test cylinders
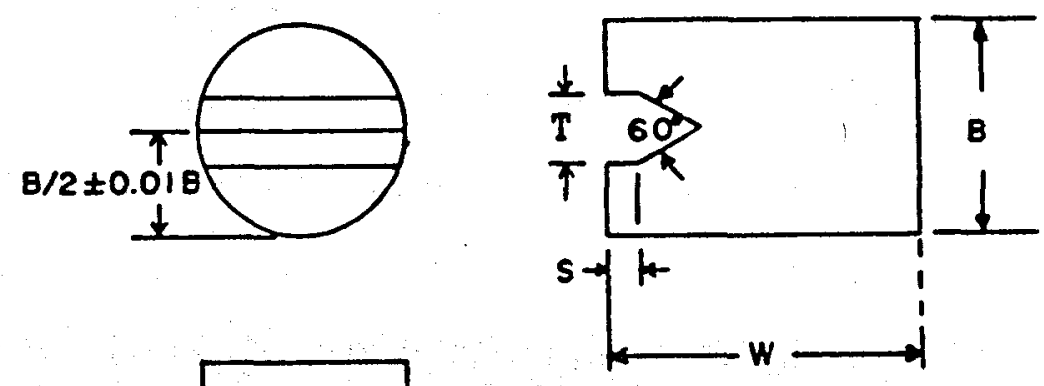

$$
\begin{aligned}
& T=.313 \times B \pm .005 \times B \\
& S=.130 \times B \pm .010 \times B
\end{aligned}
$$$$
W=1.500 \times B \pm .010 \times B
$$

$B=$ SPECIMEN DIAMETER

$25.4 \mathrm{~mm}(1 \mathrm{in}): \quad B=25.4 \pm .01 \mathrm{~mm}(1.000 \pm .004 \mathrm{in})$

$19.05 \mathrm{~mm}(3 / 4 \mathrm{in}): B=19.05 \pm .007 \mathrm{~mm}(.750 \pm .003 \mathrm{in})$

$12.7 \mathrm{~mm}(1 / 2 \mathrm{in}): \quad B=12.7 \pm .005 \mathrm{~mm}(.500 \pm .002 \mathrm{in})$

Figure 11. Short-rod specimen geometry. 
tested. Diameters as small as $1.0\left(K_{I c} / \sigma_{y s}\right)^{2}$ (where $K_{I c}$ is the toughness and $\sigma_{y s}$ is the yield strength of the steel) can be tested by the shortrod technique whereas the thickness of the ASTM E399 compact toughness specimen must be at least $2.5\left(K_{I c} / \sigma_{y s}\right)^{2} .^{7}$

Several loading devices have been developed for short-rod testing including a machine called a "fracjack", shown in Figure 12. The fracjack is installed in a tensile testing machine as illustrated in Figure 13. The specimen is placed over the grips on the fracjack (see Figure 14) and a copper chamber with cartridge heaters is installed over the steel specimen as shown in Figure 15. A thermocouple, placed in the cheveronshaped slot, is connected to a controller which supplies power to the heater cartridges. For specimens tested at elevated temperatures, the chamber was installed, brought to the desired temperature then held five minutes before applying a load. The equipment used to test $50.8 \mathrm{~mm}$ diameter short-rod samples is shown in Figure $16.25 .4 \mathrm{~mm}$ diameter specimens were tested in a Fractometer ${ }^{11}$ which employs smaller grips and a smaller heater to perform the test in the same manner. Actuating the test machine (see Figure 16) causes the grips to force the specimen mouth open. The fracjack rotates the grips as the specimen mouth is opened, which results in lines of constant load between the grips and the inside surfaces of the specimen mouth. The load applied to the specimen is plotted as a function of the mouth opening of the specimen, or Load Point Opening (LPO), which generates a load versus LPO test record, as seen in Figure 17. The initial loading slope is linear as the mouth of the specimen is elastically opened by the grips. Eventually, the load-LPO trace deviates. 


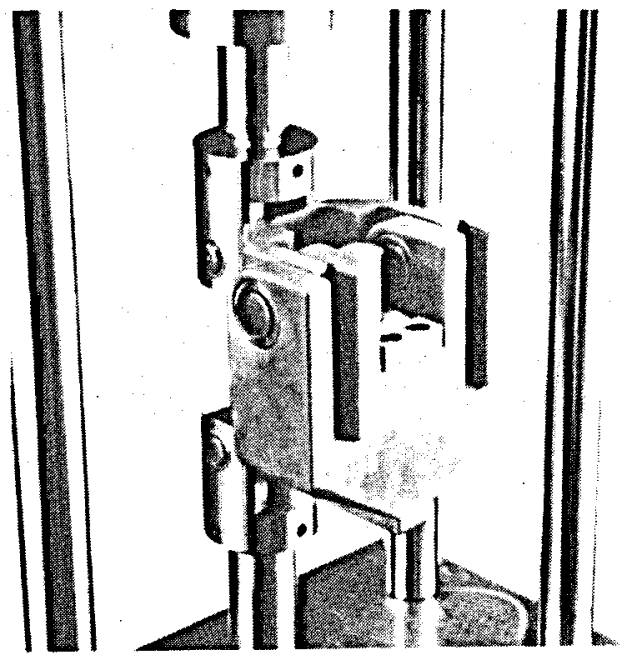

Figure 12. Fracjack loading device with specimen installed over grips.

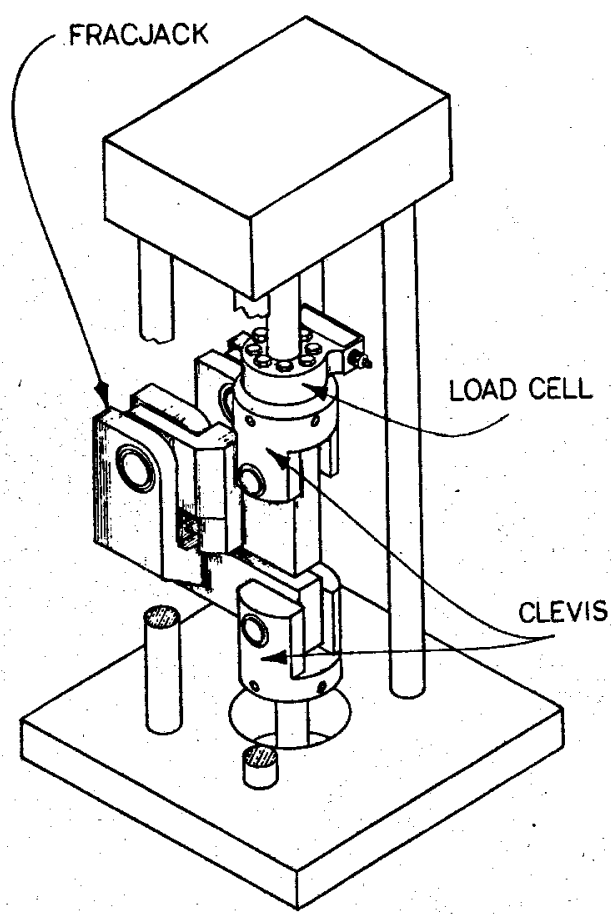

Figure 13. Fracjack located in tensile testing machine. 


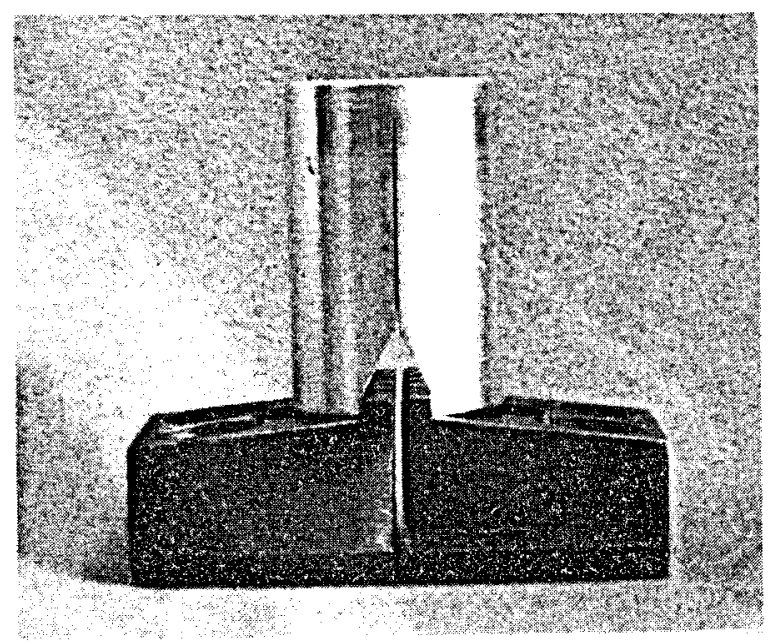

Figure 14. Installation of a specimen on the fracjack grips. The shortrod sample is shown installed on grips which have been removed from the fracjack.
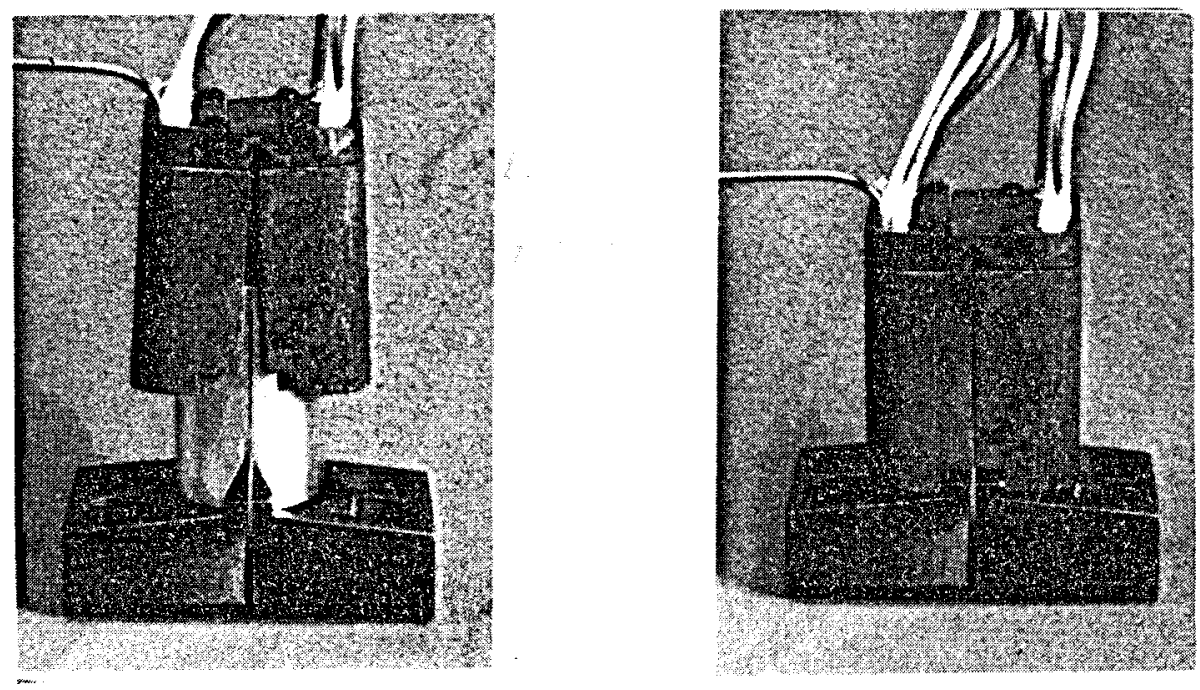

Figure 15. Installation of the temperature control chamber over a short-rod. 


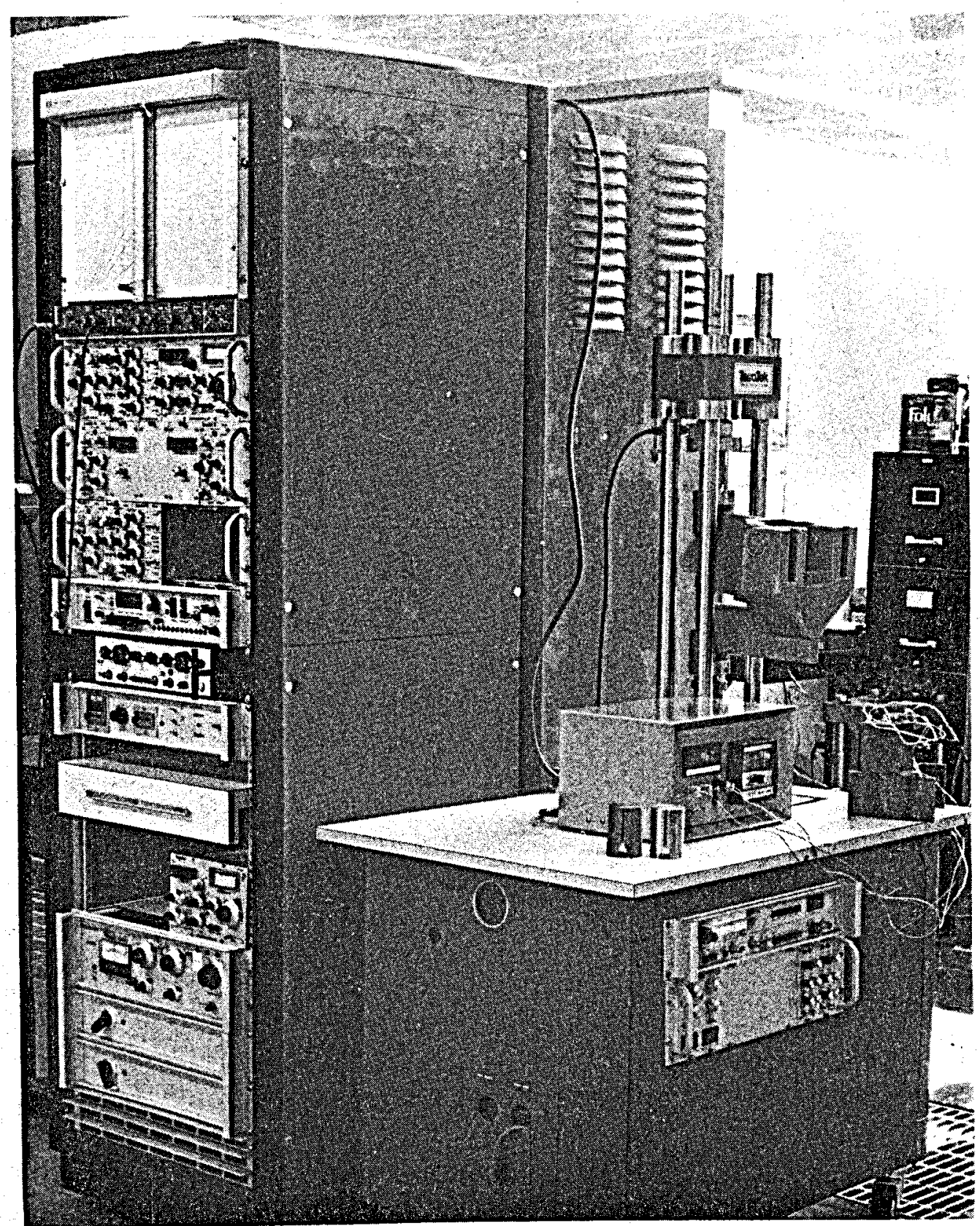

Figure 16. Tensile testing machine, control panel and temperature controller used for short-rod fracture toughness and fatigue measurements. 


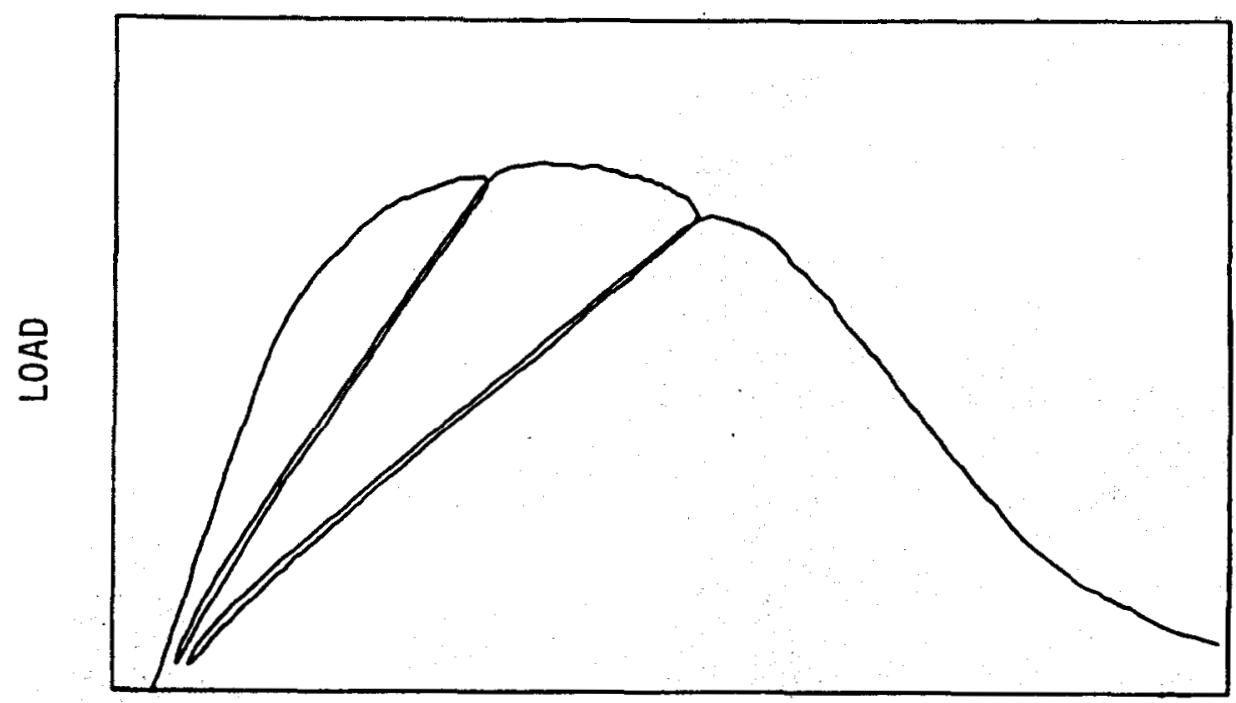

LOAD POINT OPENING

Figure 17. Load versus LPO test record for a steel sample with minimal plasticity.

from linearity indicating that a crack has initiated at the point of the v. Increasing the load causes stable crack growth which constantly widens the crack front. The fracture toughness measurement is made in the region of the maximum load after the crack has grown into the central region of the specimen. The load is released and reapplied several times during the test (two unloading-reloading sequences are seen in the test record in Figure 17) to determine and correct for residual stresses and plasticity. In several of the steel specimens tested, the plastic zone associated with the crack tip was appreciable, causing the stretched material within the zone to prop the mouth slightly open after the external load was released. The degree of plasticity is easily determined from the test record and the effect of the plastic zone on the indicated toughness is known ${ }^{7}$. 
Macroscopic residual stresses also affect the measurement of the fracture toughness by causing the test crack to be in a state of tension or compression before the application of any external load. The effects of residual stresses in short-rod specimens can be detected and compensated for in much the same way that the specimen plasticity is measured ${ }^{12}$. In some cases, the phenomenon of crack closure ${ }^{13}$ causes the unloading paths to become nonlinear after most of the unloading has occurred. Crack closure is caused by material on the crack surfaces which has been pulled out or disturbed during fracture to partially fill the space between the two fractured surfaces. The steepening of the unloading paths resulting from the early closure of the crack does not affect the fracture toughness measurement but does limit the range in which loads can be applied during fatigue testing.

Several of the steel specimens tested exhibited "crack-jump behavior" rather than the smooth crack growth described above. These specimens had load-displacement test records which consisted of a few very rapid jumps in crack position. Each crack jump was accompanied by an audible "pop" and a decrease in the applied loading force. Between the jumps, as loading continued, the crack was nearly stationary until the load was increased to a level which precipitated the next jump. Although specimens displaying crack-jump behavior do not allow for unloading-reloading cycles so that the effects of plasticity or residual stress can be included in the determination of fracture toughness, they do provide insight into the mode of fracture, as discussed later (see Results and Discussion Section). 
The loading sequence of the short-rod fracture toughness test was completed in less than one minute for specimens exhibiting either smooth crack growth of crack-jump behavior.

\section{Fatigue Crack Resistance Measurements}

Identical specimens to those used in static fracture toughness measurements were used to determine the fatigue behavior of the steels. Fatigue tests were performed at room temperature for AISI 4820,8620 and 9315 , and at $300^{\circ} \mathrm{C}$ for CBS 600, CBS $1000 \mathrm{M}$, EX-00053 and Vasco X-2M. 50.8 $\mathrm{mm}$ diameter cylinders were used for all steels except 9315 in which 25.4 $\mathrm{mm}$ diameter specimens were tested. A11 measurements were made in air and although the humidity was not monitored, it was relatively constant near 25 percent.

A Textronix 531A oscilloscope was used to monitor the load-displacement behavior for all fatigue testing and a Polaroid camera made permanent record of the tests. The sample was placed in the fracjack loading device and the appropriate temperature was obtained and monitored throughout the test. The specimen was initially loaded and the slope of the load-displacement line recorded. The specimen was then further loaded to initiate a crack before fatigue cycling began. All samples were cycled at $5 \mathrm{~Hz}$ with the specimens being loaded and unloaded in tension. The initial minimum and maximum loads were not identical for all samples since crack closure effects varied and it was necessary to avoid crack closure in all instances.

After the crack was initiated, the specimen was cycled between two constant loads and the average difference between the loads was used to determine an average $\Delta K$ in an identical manner to that used in static fracture 
toughness tests ${ }^{7}$. Crack advance was measured using previously determined compliance calibrations ${ }^{9,10}$ by correlating the change in the slope of the load-displacement curves from the oscilloscope with the initial crack length and loading slope determined at the beginning of the test. The maximum load was increased periodically throughout the test, thereby increasing $\Delta K$ and allowing several $\Delta K$ values to be measured from one sample. The loading-unloading slope, and hence the change in compliance, was recorded each time just before the load was increased and the number of cycles was also recorded from the test machine. A typical test consisted of approximately 100,000 cycles and five to ten $\Delta K$ levels. A plot of the rate of crack growth as a function of the change in toughness was made by applying the Paris power law ${ }^{14}$ :

$$
\frac{d a}{d N}=C(\Delta K)^{m}
$$

where $\mathrm{da} / \mathrm{dN}$ is the fatigue crack growth rate, $\Delta \mathrm{K}$ is the cyclic stress intensity $\left(\Delta K=K_{\max }-K_{\min }\right)$ and $C$ and $m$ are material constants dependent on frequency, temperature, environment and stress ratio. To eliminate the effect of changing stress ratio on the data ${ }^{15}$, the following relationship was used ${ }^{16}$ :

$$
\frac{d a}{d N}=\frac{C(\Delta K)^{m}}{\sqrt{1-R}}
$$

where $R$ is the stress ratio $\left(R=K_{\min } / K_{\max }\right)$ and all other symbols are the same as in Equation 1. The fatigue crack growth at a specific $\Delta K$ was determined by dividing the change in crack length $(\Delta a)$ by the of cycles $(\Delta N)$ recorded during the constant $\Delta K$ period of the test. 
RESULTS AND DISCUSSION

\section{Steel Characterization}

Only limited characterization of the steels has been performed at this time. Radian Corporation, with support from DOE/DGE Chicago Operations Program, analyzed each of the steels in the test program, with results displayed in Table 5 . The chemical analyses performed by the Timken Company for CBS 600 , CBS 1000M and 9315 (see Table 4) agree well with the Radian results except for the nickel content of 9315 . The compositional differences between the two heats of CBS 600 and CBS 1000M should be noted. It should also be observed that, as expected, EX-00053 had the lowest carbon content of the steels tested and that 9315 had a considerably lower carbon content than either 4820 or 8620 .

Radian Corporation also measured the hardness (Rockwell C) of the fractured steel specimens. Decarburization was noted on the surface of several of the samples but this had no effect on toughness or fatigue measurements because of the configuration of the test specimens. Hardness measurements were made at approximately every $1.6 \mathrm{~mm}$ from the surface to the center of each specimen, with results shown in Table 6 . The bracketed hardness value best describes the hardness in the center of the specimen. The Timken Company measured the surface hardness of test cylinders after heat treatment and found values of $41.5 \mathrm{R}_{\mathrm{c}}$ for $25.4 \mathrm{~mm}$ and $38 R_{C}$ for $50.8 \mathrm{~mm}$ specimens. The hardness at the center of CBS 600 specimens, as determined by Radian, was $R_{c} 39.0$ for $25.4 \mathrm{~mm}$ and $R_{c} 38.0$ for $50.8 \mathrm{~mm}$ specimens. Timken measured a surface hardness of $37 \mathrm{R}_{\mathrm{C}}$ for 
TABLE 5

Chemical Analysis (Percent by Weight)

\begin{tabular}{|l|c|c|c|c|c|c|c|c|c|c|c|}
\hline SteEL TYPE & $C$ & $M_{N}$ & $P$ & $S$ & $S_{I}$ & $C_{R}$ & $N_{I}$ & $M_{O}$ & $V$ & $W$ & $C_{U}$ \\
\hline 4820 & 0.18 & 0.63 & 0.008 & 0.013 & 0.29 & -- & 3.31 & 0.22 & -- & -- & -- \\
8620 & 0.20 & 0.75 & 0.007 & 0.017 & 0.19 & 0.49 & 0.46 & 0.18 & -- & -- & -- \\
9315 & 0.12 & 0.58 & 0.009 & 0.006 & 0.31 & 1.31 & 3.44 & 0.17 & -- & -- & -- \\
CBS 600 & 0.20 & 0.71 & -- & -- & 1.21 & 1.38 & -- & 1.02 & -- & -- & -- \\
CBS 600* & 0.19 & 0.63 & 0.008 & 0.006 & 1.06 & 1.58 & -- & 1.04 & -- & -- & -- \\
CBS 1000M & 0.14 & 0.57 & -- & -- & 0.50 & 0.80 & 3.20 & 4.13 & 0.32 & -- & -- \\
CBS 1000M* & 0.15 & 0.62 & 0.011 & 0.005 & 0.51 & 1.07 & 3.32 & 4.40 & 0.34 & -- & - \\
EX-00053 & 0.093 & 0.30 & -- & -- & 0.99 & 0.81 & 2.05 & 3.15 & 0.09 & -- & 1.81 \\
X-2M & 0.13 & 0.21 & -- & -- & 0.99 & 4.49 & 0.05 & 1.28 & 0.36 & 0.72 & -- \\
\hline
\end{tabular}

* Separate Heat (used for 25.4 mm cylinders).

TABLE 6

Characterization of Steels

\begin{tabular}{|c|c|c|c|c|c|c|c|}
\hline \multirow[b]{2}{*}{ Steel TyPe } & \multirow[b]{2}{*}{$\begin{array}{c}\text { HEAT } \\
\text { TREATMENT }\end{array}$} & \multirow[b]{2}{*}{ CORE HARDNESS $\left(R_{C}\right)$} & \multirow{2}{*}{$\begin{array}{c}\text { SRain SizE } \\
\text { (McQuaid EmN) }\end{array}$} & \multicolumn{2}{|c|}{$Y_{\text {IELD STRENGTH }}(2 \% \text { OFFSET })^{3}$} & \multicolumn{2}{|c|}{ TeNSILE STRENGTH $^{3}$} \\
\hline & & & & MPA & KSI & $M P_{A}$ & KSI \\
\hline $4820^{2}$ & A & $37.0-42.5(38.0)$ & $8-9$ & 869 & 126 & 1,172 & 170 \\
\hline $8620^{2}$ & B & $20.5-28.5(22.0)$ & $7-8$ & 827 & 120 & 1,151 & 167 \\
\hline $9315^{1}$ & $c$ & $34.0-39.5(35.5)$ & 7 & 848 & 123 & 1,096 & 159 \\
\hline CBS $600^{1}$ & D & $39.0-41.0(39.0)$ & 6 & 1,262 & 183 & 1,172 & 170 \\
\hline CBS $600^{2}$ & D & $37.5-39.0(38.0)$ & 6 & 1,262 & 183 & 1,172 & 170 \\
\hline CBS $1000 \mathrm{M}^{1}$ & 1 & $36.5-39.5(38.5)$ & 6 & 1,124 & 163 & 1,323 & 192 \\
\hline CBS $1000 M^{2}$ & G & $37.0-40.0(38.5)$ & $5-6$ & 1,124 & 163 & 1,323 & 192 \\
\hline$E X-00053^{2}$ & $L$ & $31.5-35.0(32.0)$ & Finer than 10 & 965 & 140 & 1,159 & 168 \\
\hline$X-2 M^{2}$ & $M$ & $37.5-40.0(38.5)$ & $8-9$ & 1,034 & 150 & 1,379 & 200 \\
\hline
\end{tabular}

1 - 25.4 MM DIAMETER SPECIMEN

2 - 50.8 MM DIAMETER SPECIMEN

3 - Manufacturer's data

4 - See Appendix A for explanation of heat treatment code. 
$50.8 \mathrm{~mm}$ CBS 1000M specimens and $43.0 \mathrm{R}_{\mathrm{C}}$ for the same heat treatment of $25.4 \mathrm{~mm}$ specimens. Radian measurements resulted in essentially identical hardness values for the two heats.

McQuaid-Ehn grain size (ASTM E112 A.3.2.1.1-78) as determined by Radian Corporation is listed in Table 6 . This procedure is based on determining the austenite grain size after carburization and does not necessarily produce a valid measure of the prior austenite grain size in specimens in the condition in which they were tested. The Timken Company etched the $25.4 \mathrm{~mm}$ diameter CBS 1000M specimens in Villela's etch and measured a prior austenite grain size of 10 to 11 , considerably finer than determined by Radian, and a structure of tempered martensite with $\mathrm{M}_{6} \mathrm{C}$ carbides. The $25.4 \mathrm{~mm}$ diameter CBS 600 specimen, quenched from $835^{\circ} \mathrm{C}$ (treatment D), when etched in 4 percent Nital, displayed a grain size of 7 and a duplex microstructure consisting of tempered martensite with 40 percent lamellar ferrite. When the same steel was austenitized at $870^{\circ} \mathrm{C}$ (treatment F), the microstructure was completely tempered martensite and the grain size was 7 to 8 . Etching of the other steels is underway to determine both ASTM grain size and microstructure. The only conclusion that can be derived from the McQuaid-Ehn grain size measurements is that the Carpenter EX-00053 steel has a very fine grain size.

Radian determined that the microstructures of 9315 , EX-00053 and $X-2 M$, after the treatments 1 isted in Appendix A, consist entirely of tempered martensite. Continuous cooling transformation diagrams predict a microstructure consisting of nearly 100 percent bainite with a trace of martensite for a $50.8 \mathrm{~mm}$ diameter 4820 rod water quenched from $780^{\circ} \mathrm{C}$ and 
an identical cylinder made of 8620 should have a microstructure at the center consisting of about 50 percent ferrite, 45 percent bainite and 5 percent martensite after water quenching from $830^{\circ} \mathrm{C}$. It is apparent that the microstructures of 4820 and 8620 will vary over the width of the crack in a short-rod specimen and that characterization of the grain size and microstructure in these steels is important. Tabulation of the yield strength and tensile strength of steels, based on manufacturer's data in Table 6, indicates that each of the candidate steels have higher strengths than the conventional steels presently in use.

Scanning electron microscopy (SEM) of the fractured surfaces was performed by Radian Corporation. Selected micrographs are displayed in Appendix B (Figures B1 through B18). The SEM micrographs seen in Figures B19 through B32 represent comparison fracture surfaces from static and fatigue test samples and were taken by Terra Tek at the University of Utah. The fracture mode was transgranular for all specimens. The degree of ductility estimated by Radian from their SEM micrographs is listed in Table 7. Also included in Table 7 is the observed crack behavior from load-displacement test records. It is interesting to note that the brittleto-ductile transitions noted in CBS 1000M, EX-00053 and X-2M between room temperature and $200^{\circ} \mathrm{C}$ correlate we 11 with the observed crack behavior from the test records. There is, however, no information from the SEM micrographs to explain the crack jump behavior observed in 8620,9315 , CBS 600 and $\mathrm{CBS} 1000 \mathrm{M}$ at high temperatures. 
TABLE 7

Fracture Mode Based on SEM Micrographs

$\div$

\begin{tabular}{|c|c|c|c|}
\hline Steel Type & $\begin{array}{l}\text { Fracture Temperature } \\
\left({ }^{\circ} \mathrm{C}\right)\end{array}$ & Degree of Ductility & $\begin{array}{l}\text { Crack } \\
\text { Behavior }\end{array}$ \\
\hline 4820 & $\begin{array}{c}\mathrm{RT}+ \\
100 \\
200 \\
300\end{array}$ & $\begin{array}{l}A \\
A \\
A \\
A\end{array}$ & $\begin{array}{l}S \\
S \\
S \\
S\end{array}$ \\
\hline 8620 & $\begin{array}{r}\text { RT } \\
100 \\
200 \\
300\end{array}$ & $\begin{array}{l}C \\
B \\
A \\
A\end{array}$ & $\begin{array}{c}S \\
S \\
S \\
S-J\end{array}$ \\
\hline 9315 & $\begin{array}{r}\text { RT } \\
100 \\
200 \\
300\end{array}$ & $\begin{array}{l}A \\
A \\
A \\
A\end{array}$ & $\begin{array}{c}S \\
S \\
S \\
S-J\end{array}$ \\
\hline CBS 600 & $\begin{array}{r}\mathrm{RT} \\
100 \\
200 \\
300 \\
400\end{array}$ & $\begin{array}{l}A \\
A \\
A \\
A \\
A\end{array}$ & $\begin{array}{l}S \\
S \\
S \\
S \\
J\end{array}$ \\
\hline CBS $1000 \mathrm{M}$ & $\begin{array}{r}R T \\
100 \\
200 \\
300 \\
400\end{array}$ & $\begin{array}{l}D \\
A \\
A \\
A \\
A\end{array}$ & $\begin{array}{l}J \\
S \\
S \\
S \\
J\end{array}$ \\
\hline$E X-00053$ & $\begin{array}{r}R T \\
100 \\
200 \\
300 \\
400\end{array}$ & $\begin{array}{l}B \\
A \\
A \\
A \\
A\end{array}$ & $\begin{array}{l}J \\
S \\
S \\
5 \\
S\end{array}$ \\
\hline$X-2 M$ & $\begin{array}{r}\text { RT } \\
100 \\
200 \\
300 \\
400\end{array}$ & $\begin{array}{l}E \\
E \\
B \\
A \\
A\end{array}$ & $\begin{array}{l}\mathrm{J} \\
\mathrm{J} \\
\mathrm{S} \\
\mathrm{S} \\
\mathrm{S}\end{array}$ \\
\hline
\end{tabular}

+ RT - Rooin Temperature

A - Ductile, microvoid coalescence

B - Mixed Mode, less than 25\% brittle cleavage

C - Mixed Mode, 25-75". brittle cleavage

D - Mixed Mode, greater than $75^{\prime \prime}$ brittle cleavage

E - Brittle Cleavage
S - Smooth Crack Growth

$\mathrm{J}$ - Crack Jump Behavior S-J-Borderline Between Smooth and Crack Jump 
Fracture Toughness

The experimental data from static fracture toughness tests are tabulated in Appendix $A$ along with heat treatments. A description and interpretation of the data follow.

AISI 4820: The toughness of 4820 (heat treatment A) as a function of temperature is shown in Figure 18. The steel was tested with slots and grip grooves machined before heat treating, as well as machining performed after heat treating, with no observed difference in the fracture toughness. The fracture toughness declines steadily with temperature to $200^{\circ} \mathrm{C}$ and then increases slightly between 200 and $300^{\circ} \mathrm{C}$. SEM micrographs revealed dimpled rupture indicative of ductile fracture at all temperatures. Although there is no obvious reason for the decrease in toughness with temperature, the increase above $200^{\circ} \mathrm{C}$ may be due to microstructural changes occuring during the test, because the tempering temperature was only $230^{\circ} \mathrm{C}^{17}$. The important observation is that the toughness at $200^{\circ} \mathrm{C}$ is only half the value of the fracture toughness at room temperature.

AISI 8620: The low hardenability of 8620 (heat treatment B), relative to other steels tested, caused differences in the fracture toughness depending on whether the cylinders were slotted before or after heat treating (see Figure 19). The specimens heat treated after slotting showed considerable scatter between tests due to residual stresses arising from quenching and phase transformation. The specimens quenched without slots displayed consistently higher toughness at room temperature and $300^{\circ} \mathrm{C}$ then their slotted counterparts, but no difference was observed at 


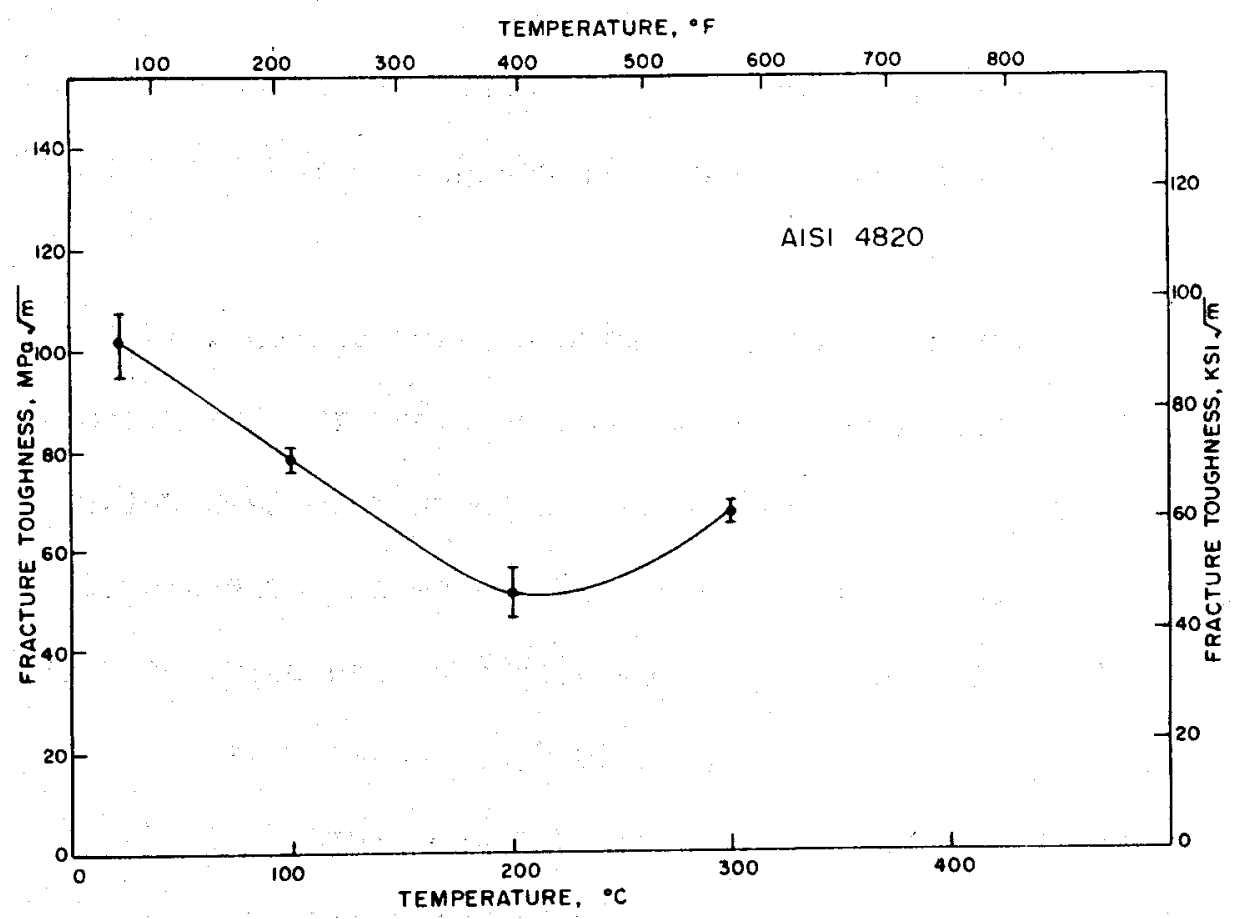

Figure 18. Fracture toughness as a function of temperature for 4820 (heat treatment $A$ ).

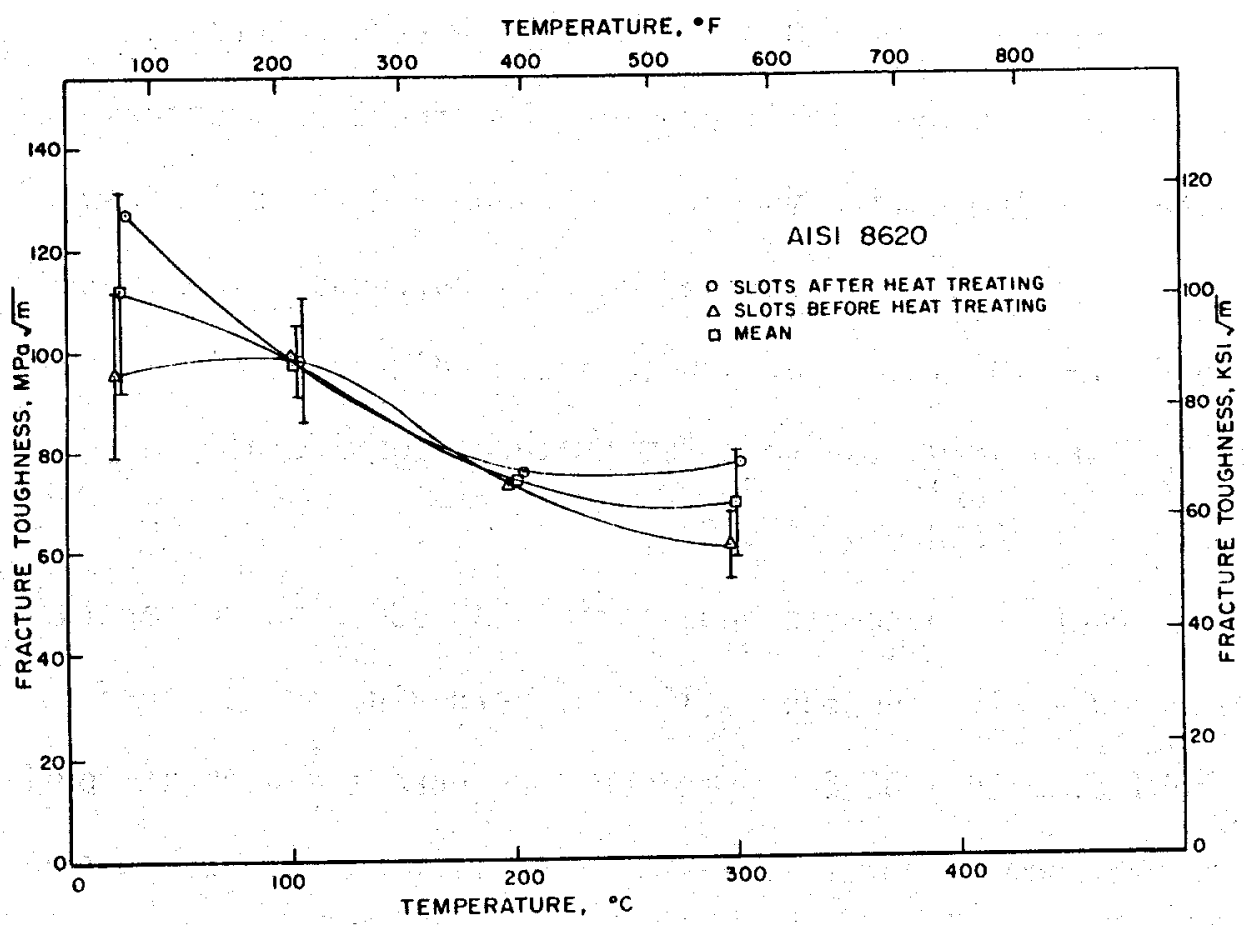

Figure 19. Effect of temperature on the toughness of 8620 (heat treatment $B$ ). 
$100^{\circ} \mathrm{C}$ and $200^{\circ} \mathrm{C}$. As for 4820 , the $300^{\circ} \mathrm{C}$ test temperature exceeded the $230^{\circ} \mathrm{C}$ tempering temperature, so microstructural changes during the test were inevitable.

The obvious trend, regardless of the timing of slot cutting, is a drop in toughness with temperature, despite the fact that the SEM micrographs indicate some degree of brittle cleavage at both room temperature and $100^{\circ} \mathrm{C}$ and ductile fracture by microvoid coalescence at temperatures of $200^{\circ} \mathrm{C}$ and $300^{\circ} \mathrm{C}$. The most serious problem with 4820 and 8620 , however, is the drop in hardness between ambient and $200^{\circ} \mathrm{C}$, since wear is greatly accelerated in these steels by increased temperature.

AISI 9315: The 9315 steel (heat treatment C), with its entirely martensitic structure as well as high nickel and low carbon contents, displayed the best toughness of any of the conventional steels tested. The toughness decreased only from $120.7 \mathrm{MPa} \sqrt{\mathrm{m}}$ at room temperature to 88.0 MPa $\sqrt{\mathrm{m}}$ at $300^{\circ} \mathrm{C}$, as displayed in Figure 20 . The fracture toughness of 9315 is adequate over the entire temperature range and the only drawback to this steel is its poor wear resistance (low hardness) at elevated temperatures (see Figure 10) in comparison to the candidate steels in the program. As for 8620 and 4820 , the test temperatures considerably exceeded the tempering temperature of $175^{\circ} \mathrm{C}$.

CBS 600: The fracture toughness behavior of CBS 600 with temperature is illustrated in Figure 21 . The $835^{\circ} \mathrm{C}\left(1535^{\circ} \mathrm{F}\right)$ hardening temperature of the $50.8 \mathrm{~mm}$ ( 2 inch) diameter CBS 600 specimens produced the highest toughness $(154.1 \mathrm{MPa} \sqrt{\mathrm{m}})$ in room temperature tests. The microstructure had considerable ferrite mixed with the martensite. When the same heat treatment 


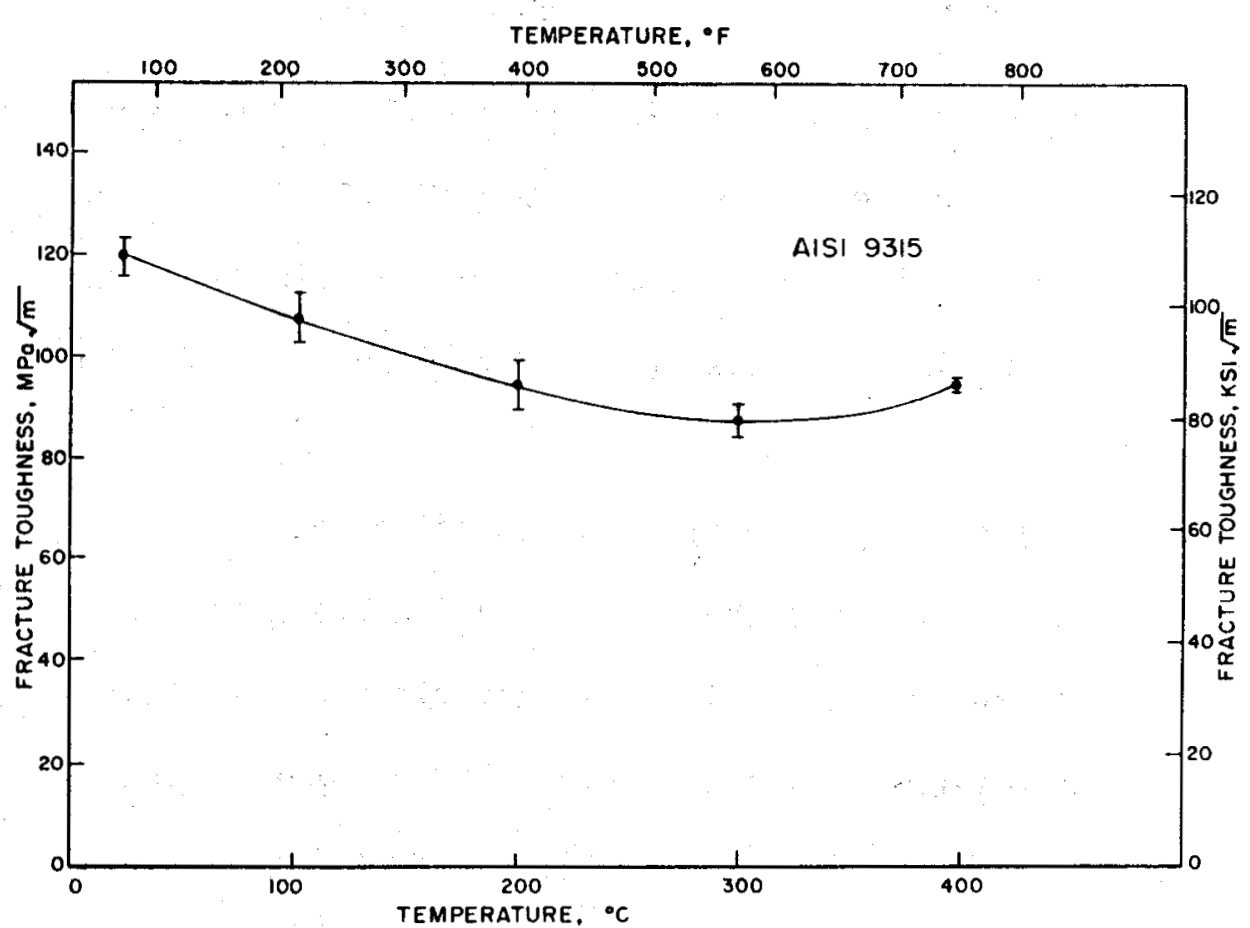

Figure 20. Fracture toughness of 9315 as a function of temperature (heat treatment $\mathrm{C}$ ).

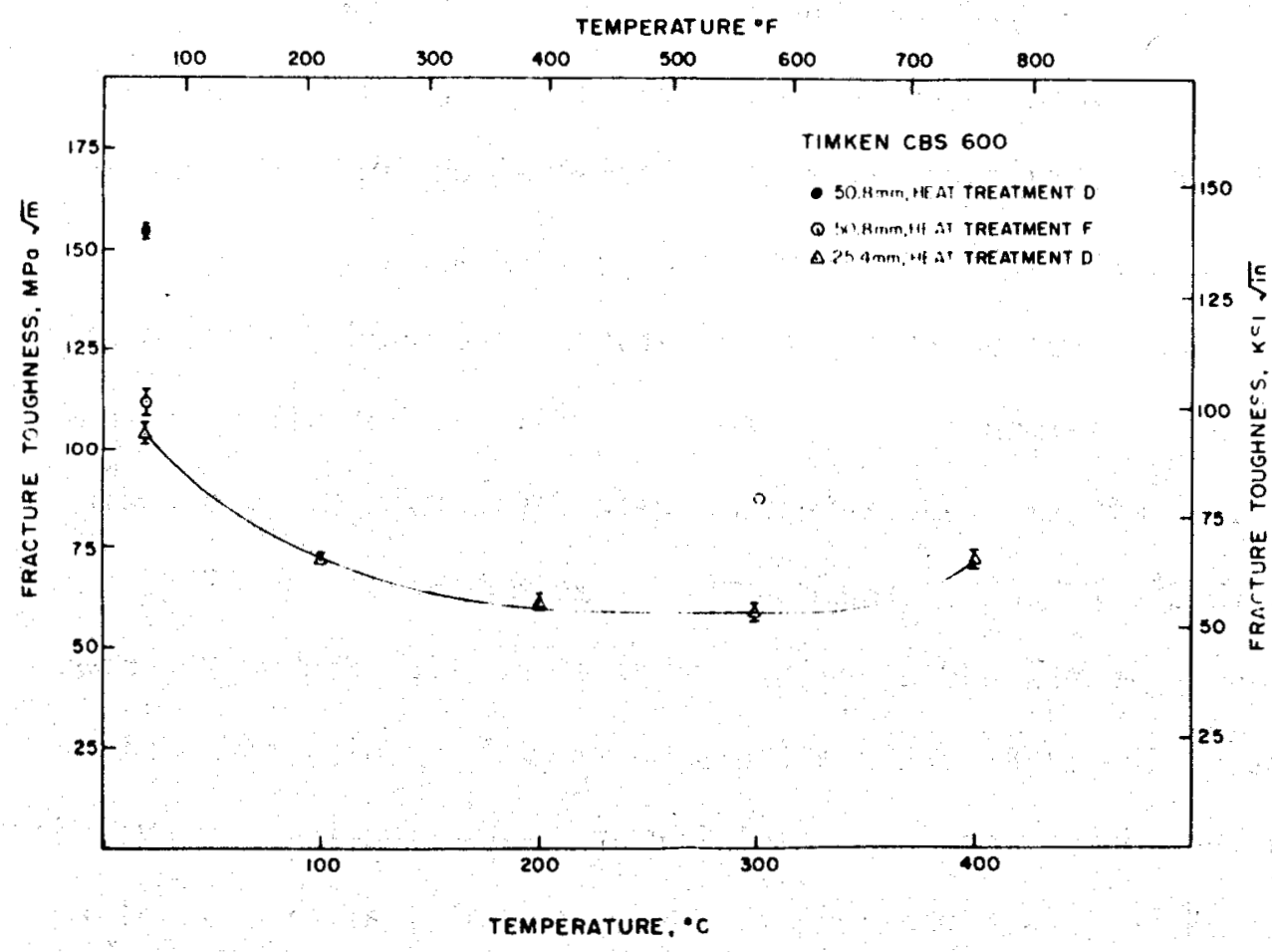

Figure 21. Effect of temperature on the toughness of CBS 600 . 
was applied to $25.4 \mathrm{~mm}$ diameter specimens, 40 percent lamellar ferrite was observed. The $25.4 \mathrm{~mm}$ specimens were significantly less tough at room temperature than were the $50.8 \mathrm{~mm}$ specimens (see Appendix A). The toughness of the $25.4 \mathrm{~mm}$ specimen drops sharply from 103.5 to $61.5 \mathrm{MPa} \sqrt{\mathrm{m}}$ between room temperature and $200^{\circ} \mathrm{C}$.

The $870^{\circ} \mathrm{C}\left(1600^{\circ} \mathrm{F}\right)$ hardening temperature produced an entirely martensitic microstructure with about the same austenite grain size as the $835^{\circ} \mathrm{C}$ "austenitizing" temperature. It is interesting to note that the 100 percent tempered martensite microstructure had a lower toughness at room temperature $(111.4 \mathrm{MPa} \sqrt{\mathrm{m}})$ than the ferrite-martensite cylinders of the same size. The room temperature hardness was $42.5 \mathrm{R}_{\mathrm{C}}$ for the martensitic structure and $38.0 \mathrm{R}_{\mathrm{c}}$ for the martensite-ferrite microstructure indicating a trade-off in hardness and toughness. A cylinder hardened at $870^{\circ} \mathrm{C}$ had a toughness of $86.9 \mathrm{MPa} \sqrt{\mathrm{m}}$ at $300^{\circ} \mathrm{C}$, perhaps indicating that a totally martensitic structure may retain toughness better with increasing temperature than microstructures containing ferrite.

CBS 1000M: Three austenitizing temperatures were used in determining the effects of heat treatments on $K_{I C}$ (see Appendix $A$ ), but all specimens had microstructures of tempered martensite with $M_{6} C$ carbides. The grain size after the $1090^{\circ} \mathrm{C}\left(2000^{\circ} \mathrm{F}\right)$ treatment was 7 to 8 whereas the $955^{\circ} \mathrm{C}$ $\left(1750^{\circ} \mathrm{F}\right)$ treated cylinders had a grain size of 10 to 11 . Figure 22 shows that, as expected, the finer-grained (hexagon shaped symbols) had a higher toughness than the coarser-grained steel (triangles). The $25.4 \mathrm{~mm}$ cylinders austenitized at $955^{\circ} \mathrm{C}$ (heat treatment I, square symbols) after a simpler heat treatment than its $50.8 \mathrm{~mm}$ counterpart (heat treatment $G$, hexagons) 


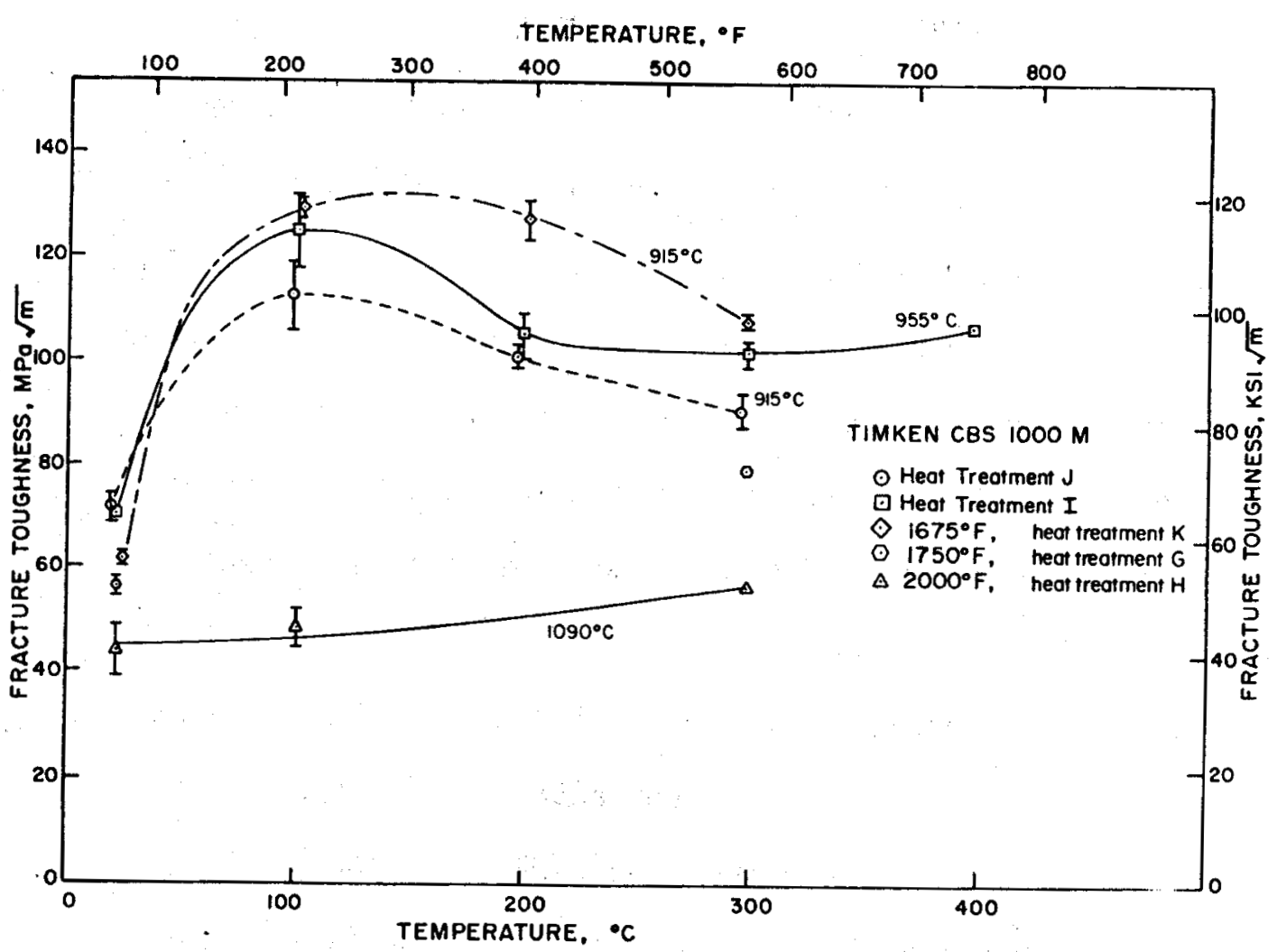

Figure 22. Temperature dependence of toughness for CBS 1000M.

had a higher hardness $\left(43 R_{c}\right.$ versus $37 R_{c}$ ) as well as increased toughness ( $80.0 \mathrm{MPa} \sqrt{\mathrm{m}}$ versus $57.1 \mathrm{MPa} \sqrt{\mathrm{m}}$ ). As previously discussed, the hardness of this steel is in question since Radian measured a hardness of 39.5-38.5 $R_{c}$ at the center of both size cylinders. It is obvious, however, that hardness is not always sacrificed when improved toughness is obtained.

The most intriguing result of the CBS $1000 \mathrm{M}$ tests was the large increase in toughness between room temperature and $100^{\circ} \mathrm{C}$. This increase in toughness correlates well with the brittle-to-ductile fracture transition of this steel as seen in micrographs B9-B11 (Appendix B). A11 CBS $1000 \mathrm{M}$ specimens had excellent toughness retention over the entire temperature range. 
Except for austenitizing at $1090^{\circ} \mathrm{C}$, all the heat treatments given CBS $1000 \mathrm{M}$ produced adequate toughness for any drilling application above room temperature. The low ambient temperature toughness, as compared to 4820,8620 and 9315 , would limit the use of this steel in the cold environments sometimes encountered in normal rock drilling. As can be seen from Figure 10, the CBS $1000 \mathrm{M}$ has the best wear resistance of any steel in the test program. However, its high cost and elaborate heat treatment militate against its wide-spread use.

EX-00053: The room temperature toughness (103.6 MPa $\sqrt{\mathrm{m}}$ ) of EX-00053, heat treatment $\mathrm{L}$, is comparable to that of conventional steels but the increase in toughness at $100^{\circ} \mathrm{C}$ is phenomenal $(265 \mathrm{MPa} \sqrt{\mathrm{m}})$. The steel appears to be going through a brittle-to-ductile transition (see figures $B 13$ and B14, Appendix B) in this temperature range (see Figure 23). Even in $50.8 \mathrm{~mm}$ diameter specimens and employing the short-rod technique, the toughness is difficult to measure because of the large plastic zone in the test cylinders. The EX-00053 steel should be an excellent candidate for any application requiring exceptional toughness at elevated temperatures. Further studies are essential to determine the cause of the rapid increase in toughness of this steel in a small temperature interval.

X-2M: The $X-2 M$ steel displayed the most consistent toughness behavior as a function of temperature of any steel tested (see Figure 24). Unfortunately, the toughness of this steel is also the lowest of any tested and although it is comparable to 4820 and 8620 in the 200 to $300^{\circ} \mathrm{C}$ range, the low room temperature toughness does not make this steel a promising candidate for geothermal rock bits since the bits must be able to withstand 


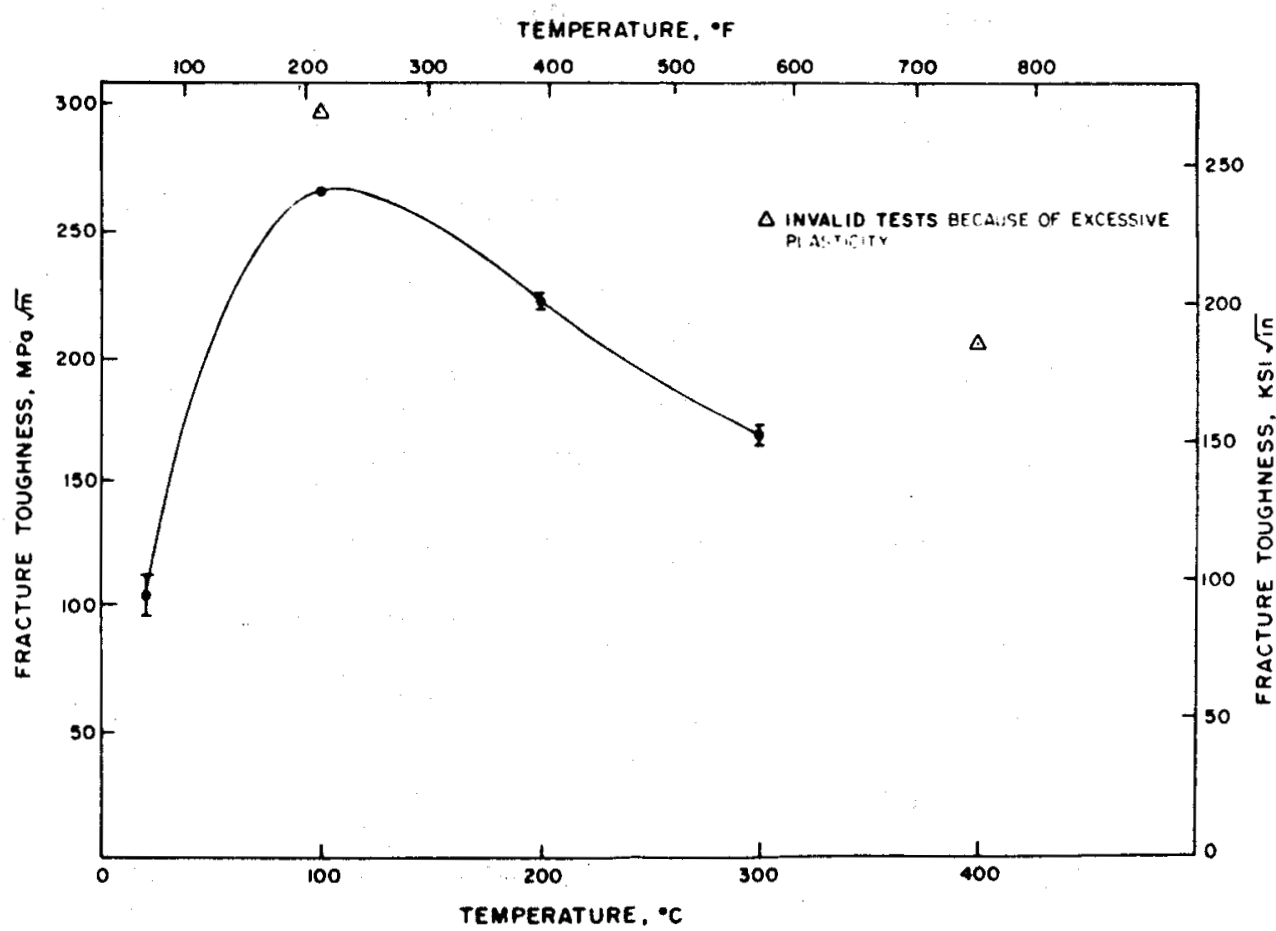

Figure 23. Effect of test temperature on fracture toughness of EX-00053 (heat treatment L).

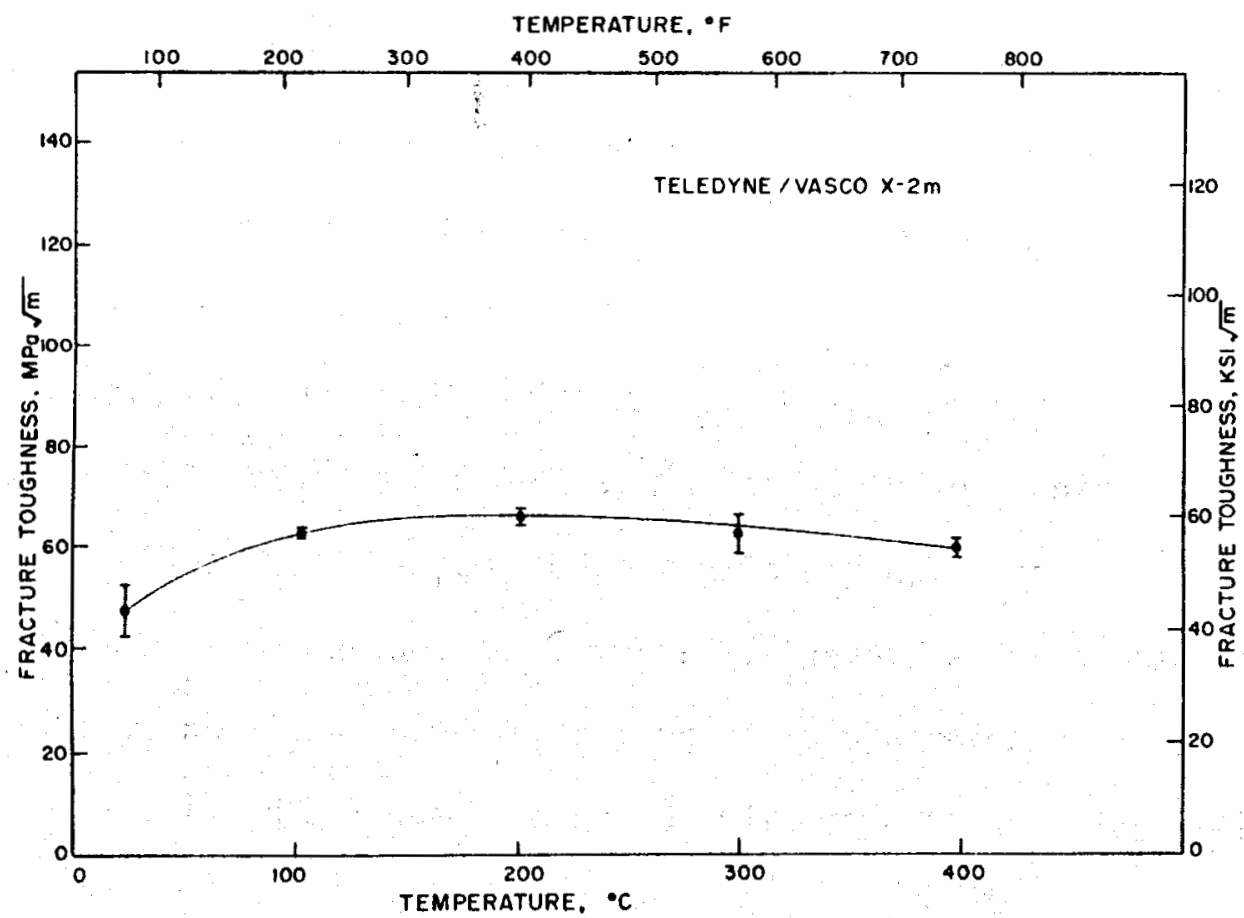

Figure 24. Effect of temperature on the toughness of $X-2 M$ (heat treatment $M$ ). 
impact during fabrication and shipping. The main problem with this steel, however, is the high austenitizing temperature $\left(1120^{\circ} \mathrm{C}\right)$ which calls for furnace equipment not generally used by bit manufacturers .

One interesting result of the $X-2 M$ tests is the excellent correlation between the crack behavior observed on the test record and the brittle-to-ductile transition temperature (see Table 7). The SEM micrographs (see Figures $\mathrm{B} 15-\mathrm{B} 18$ ) reveal that the steel changes from very brittle cleavage to ductile fracture between $100^{\circ} \mathrm{C}$ and $200^{\circ} \mathrm{C}$, accompanied by a change from crack-jump behavior to smooth crack growth. Surprisingly, there was not corresponding increase in toughness between $100^{\circ} \mathrm{C}$ and $200^{\circ} \mathrm{C}$.

The toughness of the steels tested is compared in Figure 25 . It is very apparent that EX-00053 has superior toughness at elevated temperatures and that CBS 1000M is the only other steel which has $K_{I C}$ values equal or superior to 9315 . The other obvious trend is that steels with tempered martensite structures (X-2M, 9315, CBS 1000M, EX-00053) have much better toughness retention with increasing temperature than steels containing ferrite or bainite $(4820,8620$ and CBS 600). These latter steels drop rapidly in toughness with increasing temperature. Although all of the steels, with the possible exception of $X-2 M$, may be capable of resisting fracture during geothermal drilling, EX-00053 and CBS 1000M appear to be the only steels capable of resisting impact fracture if reamers and bits made of these materials are used at conventional penetration rates. The obvious advantage of using a highly wear-resistant steel would be to drill faster and longer with the same or reduced bearing wear. 


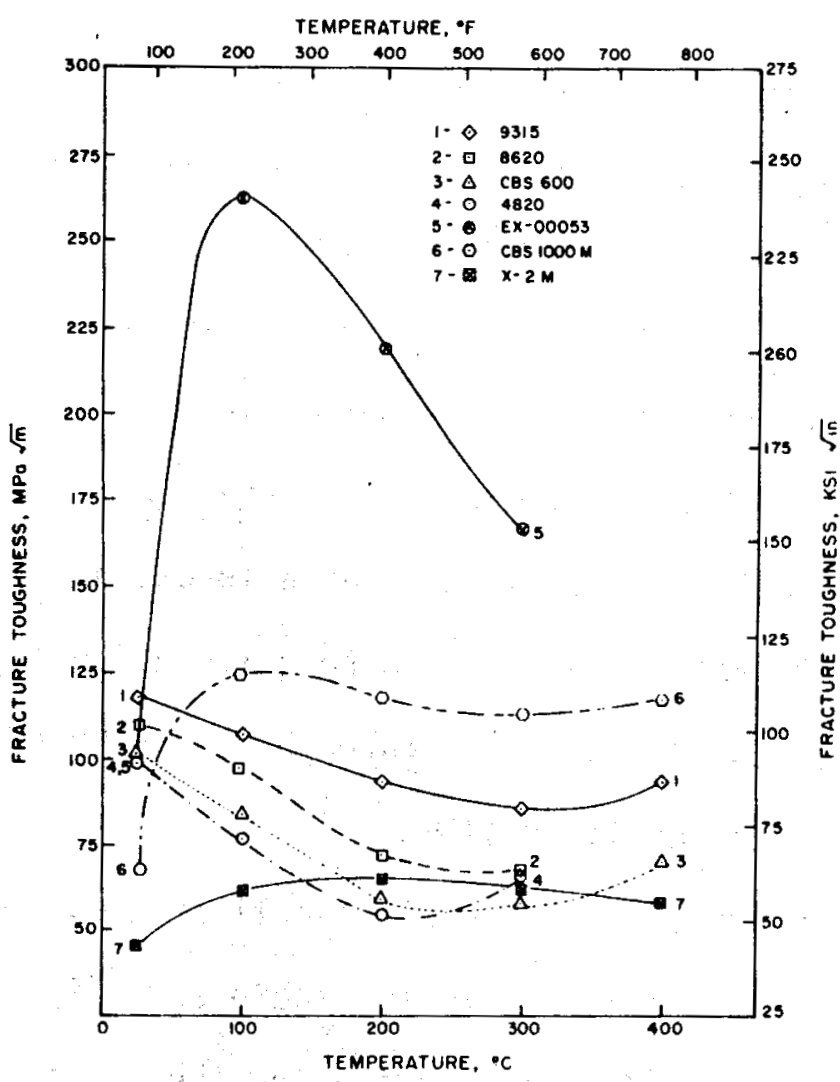

Figure 25. Toughness comparison of conventional and high wear resistant steels.

\section{Fatigue Crack Resistance Measurements}

Extensive data ${ }^{18}$ on fatigue crack growth behavior in metallic systems have been generated. These studies have proven the validity of the Paris power law in the region where stable crack growth occurs ${ }^{16}$. The approach is useful because a knowledge of fracture toughness and fatigue properties allows an estimate to be made of the maximum allowable initial flaw size if the operating stress level is known. Alternatively, it is possible to estimate a maximum allowable stress for a given flaw which will not allow it to grow to critical dimensions during the intended life of the component $^{16}$. Although fatigue data are not presently used to predict bit failure, it was believed that wear-resistant steels should have fatigue 
behavior at high temperatures similar to that of conventional bit steels at room temperature. This maybe an over-simplification since conventional rock bits certainly operate at elevated temperatures.

It was expected that $m$ values from the Paris power law ${ }^{16}$ would be in the range of two to four for all steels tested and that the slopes would simply be shifted to higher or lower crack propagation rates if a log-log plot of crack propagation rate was made as a function of stress intensity factor. The test results, however, were quite different, as can be seen in Table 8, and in Figures 26 through 33. A brief discussion of the individual test results follows.

AISI 4820: Although no data were found in the literature for crack propagation rates in 4820 , the results shown in Figure 26 indicating an $m$ value of 3.05 are reasonable. The line indicating the fit of the data is extended beyond the actual data points and it should be noted that the curve will bend down at low propagation rates and curve up at higher rates due to crack initiation and unstable crack growth, respectively. It is generally believed that the region between 0.1 and $10 \mu \mathrm{m} / \mathrm{cycle}$ is well within the stable region (often refered to as Region 2) of crack growth. 4820 showed little crack closure and as stated earlier, crack closure was avoided for all tests since cracks do not propagate when the crack has closed.

AISI 8620: An exceptionally high $m$ value (11.38) was calculated from the test data and individual tests indicated an even higher $m$ value of approximately 13.6. The first test was conducted with a specimen which was slotted before heat treating while the second test used a 


\section{TABLE 8}

Fatigue Crack Resistance Results

\begin{tabular}{|c|c|c|c|c|c|c|c|}
\hline Steel Type & $\begin{array}{l}\text { Test Temperature } \\
\left({ }^{\circ} \mathrm{C}\right)\end{array}$ & Test & $\frac{k_{\max }}{(\mathrm{MPa} \cdot \bar{m})}$ & $c^{*}$ & $M^{*}$ & $r$ & $\begin{array}{l}\text { Results Displayed } \\
\text { in Figure }\end{array}$ \\
\hline 4820 & $\begin{array}{l}\mathrm{RT}^{\mathrm{F}} \\
\mathrm{RT}\end{array}$ & $\begin{array}{c}1 \\
2 \\
\text { Comb ined }\end{array}$ & $\begin{array}{l}62.6 \\
60.8 \\
62.6\end{array}$ & $\begin{array}{l}4.14 \times 10^{-10} \\
5.90 \times 10^{-10} \\
4.87 \times 10^{-10}\end{array}$ & $\begin{array}{l}3.14 \\
2.98 \\
3.05\end{array}$ & $\begin{array}{l}0.92 \\
0.98 \\
0.96\end{array}$ & 26 \\
\hline 8620 & $\begin{array}{l}\text { RT } \\
\text { RT }\end{array}$ & $\begin{array}{c}1 \\
2 \\
\text { Combined }\end{array}$ & $\begin{array}{l}70.1 \\
80.7 \\
80.7\end{array}$ & $\begin{array}{l}1.67 \times 10^{-2} \\
7.91 \times 10^{-26} \\
2.36 \times 10^{-22}\end{array}$ & $\begin{array}{l}13.83 \\
13.43 \\
11.38\end{array}$ & $\begin{array}{l}0.97 \\
0.92 \\
0.75\end{array}$ & 27 \\
\hline 9315 & $\begin{array}{l}\text { RT } \\
\text { RT }\end{array}$ & $\begin{array}{c}1 \\
2 \\
\text { Combined }\end{array}$ & $\begin{array}{l}73.4 \\
78.4 \\
78.4\end{array}$ & $\begin{array}{l}1.23 \times 10^{-7} \\
8.73 \times 10^{-3} \\
1.71 \times 10^{-4}\end{array}$ & $\begin{array}{l}1.46 \\
2.16 \\
1.97\end{array}$ & $\begin{array}{l}0.57 \\
0.89 \\
0.82\end{array}$ & 28 \\
\hline CBS 600 & $\begin{array}{l}300 \\
300\end{array}$ & $\begin{array}{c}1 \\
2 \\
\text { Combined }\end{array}$ & $\begin{array}{l}65.4 \\
51.1 \\
65.4\end{array}$ & $\begin{array}{l}2.24 \times 10^{-17} \\
2.10 \times 10^{-11} \\
1.69 \times 10^{-12}\end{array}$ & $\begin{array}{l}7.99 \\
4.29 \\
4.92\end{array}$ & $\begin{array}{l}0.62 \\
1.00 \\
0.40\end{array}$ & 29 \\
\hline CBS $1000 \mathrm{M}$ & $\begin{array}{l}300 \\
300\end{array}$ & $\begin{array}{c}1 \\
2 \\
\text { Combined }\end{array}$ & $\begin{array}{l}49.7 \\
64.0 \\
64.0\end{array}$ & $\begin{array}{l}7.88 \times 10^{-1} \\
4.22 \times 10^{-10} \\
1.22 \times 10^{-2}\end{array}$ & $\begin{array}{l}8.24 \\
3.19 \\
2.36\end{array}$ & $\begin{array}{l}0.96 \\
0.95 \\
0.40\end{array}$ & 30 \\
\hline EX-00053 & $\begin{array}{l}300 \\
300\end{array}$ & $\begin{array}{l}\frac{1}{2} \\
\text { Conth ined }\end{array}$ & $\begin{array}{l}94.6 \\
70.8 \\
94.8\end{array}$ & $\begin{array}{l}1.08 \times 10^{-1+} \\
2.55 \times 10^{-1} \\
6.68 \times 10^{-11}\end{array}$ & $\begin{array}{l}6.64 \\
1.01 \\
4.68\end{array}$ & $\begin{array}{l}0.96 \\
0.11 \\
0.59\end{array}$ & 31 \\
\hline$X-2 M$ & $\begin{array}{l}300 \\
300\end{array}$ & $\begin{array}{c}1 \\
2 \\
\text { Combined }\end{array}$ & $\begin{array}{l}46.5 \\
52.1 \\
52.1\end{array}$ & $\begin{array}{l}1.80 \times 10^{-1} \\
2.77 \times 10^{-1} \\
7.64 \times 10^{-14}\end{array}$ & $\begin{array}{l}5.74 \\
6.40 \\
6.04\end{array}$ & $\begin{array}{l}0.89 \\
0.98 \\
0.93\end{array}$ & 32 \\
\hline
\end{tabular}

A - $K_{\text {max }}=$ Maximum stress intensity factor durina test

1. - C,M $=$ Constants as defined in Equation (2)

$-r=$ Correlation coefficient squared : - RT $=$ Room temperature

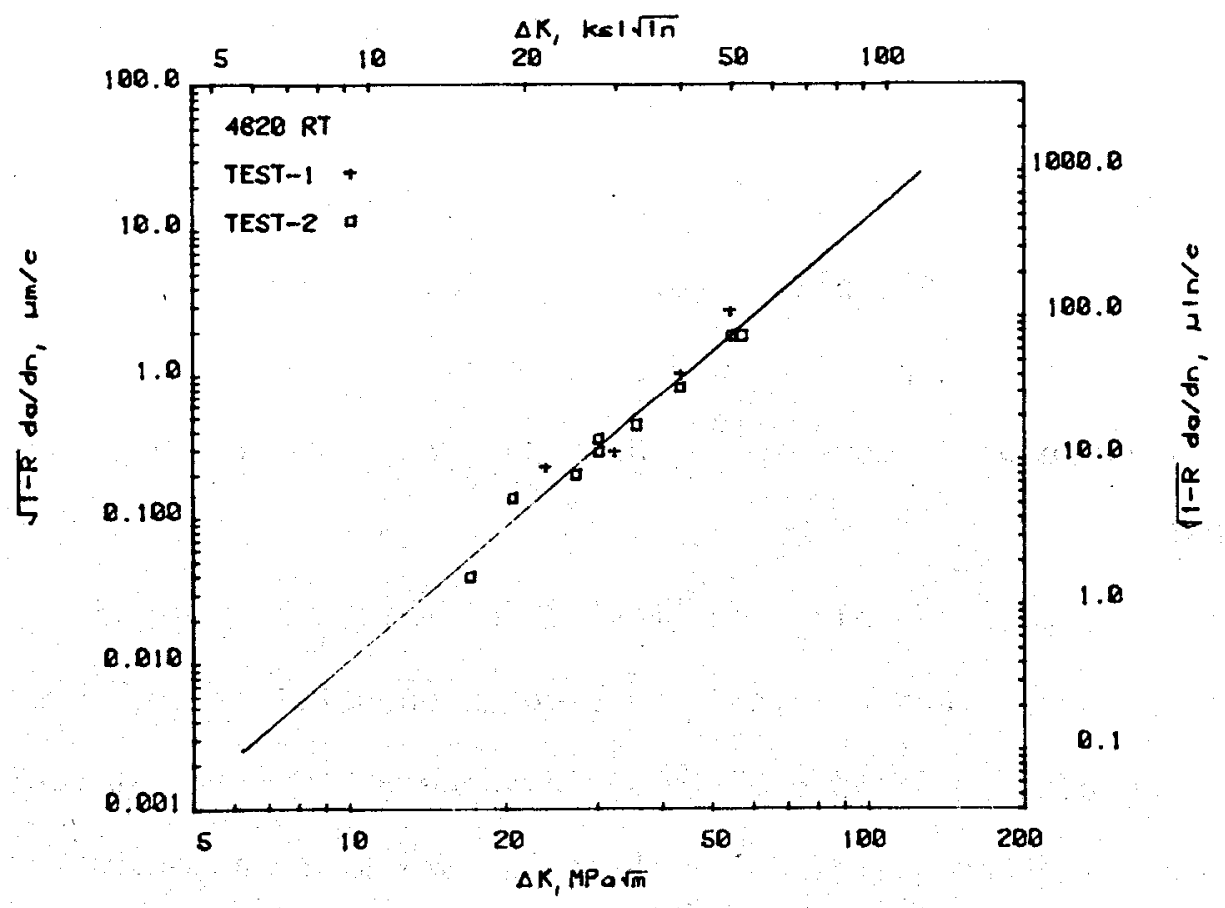

Figure 26. Crack growth rate as a function of stress intensity factor for AISI 4820. 
cylinder which had been heat treated and then slotted. The similar results for both tests, as shown in Figure 27, indicate that residual stresses and microstructure were not the main reason for the anomalously high $m$ value. The 8620 steel, however, displayed significant crack closure, such that a $K_{\min }$ of $50 \mathrm{MPa} \sqrt{\mathrm{m}}$ and $62 \mathrm{MPa} \sqrt{\mathrm{m}}$ were used for the two tests. The maximum stress intensity, $80.7 \mathrm{MPa} \sqrt{\mathrm{m}}$, used in the second test approaches 70 percent of $\mathrm{K}_{\mathrm{IC}}$. Although many investigators have produced evidence of accelerating rates of fatigue crack growth approaching final fracture, the separate contributions of $\Delta K$ and $K_{\max }$ have not been carefully examined ${ }^{19}$. It appears that both $\Delta K$ and $K_{\max }$ contribute towards the accelerating rates of crack propagation as the conditions for failure are approached. The high values of $K_{\min }$ and $K_{\max }$ required to reach the 20-40 MPa $\sqrt{m} \Delta K$ range, due to crack closure, were apparently the cause of the steep slope of the $\log -\log$ plot. It should be stressed that crack closure is not a peculiarity of the short-rod technique but is caused by plastic deformation or residual stresses within the specimens. The anomalous behavior is not entirely explained by crack closure constraints since high $K_{\max } / K_{I c}$ ratios would normally cause crack growth rates above $10 \mu \mathrm{m} /$ cycle if catastrophic failure were occuring ${ }^{19}$. No data were found in the literature for AISI 8620.

AISI 9315: 9315 was the only steel tested for which previous literature data could be found. Crack initiation studies on $9315^{20}$ showed crack initiation occuring between 4 and $6 \mathrm{MPa} \sqrt{\mathrm{m}}$ and a value of $10 \mathrm{MPa} \sqrt{\mathrm{m}}$ at 0.01 $\mu \mathrm{m} /$ cycle. Figure 28 agrees quite well with these data since an extrapolation of the observed data for 9315 gives a $\Delta K$ of $5 \mathrm{MPa} \sqrt{\mathrm{m}}$ at $0.01 \mu \mathrm{m} / \mathrm{cycle}$. An $m$ value near 2 is also consistent with what would be expected for room temperature measurements on this stee ${ }^{16}$. 


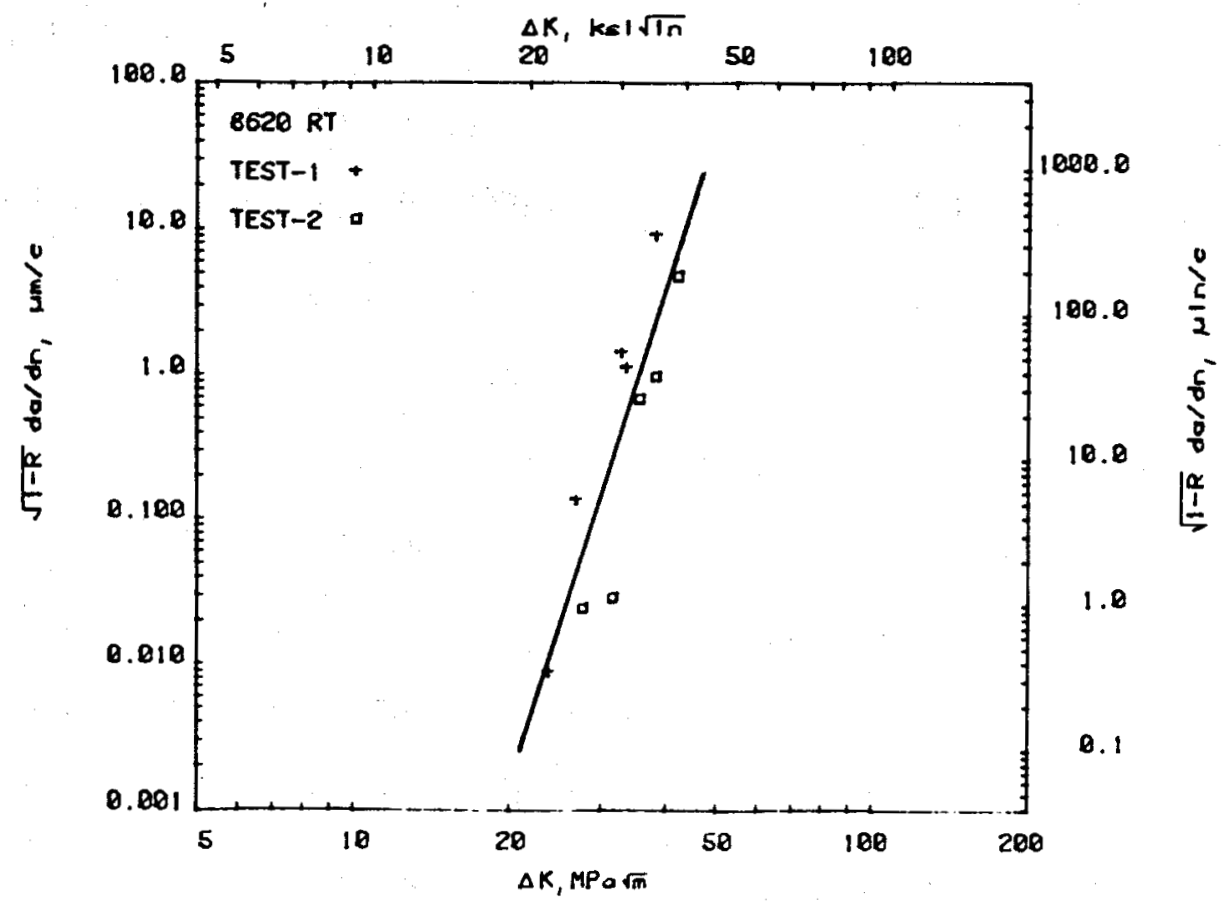

Figure 27. Crack growth rate as a function of stress intensity factor for AISI 8620 .

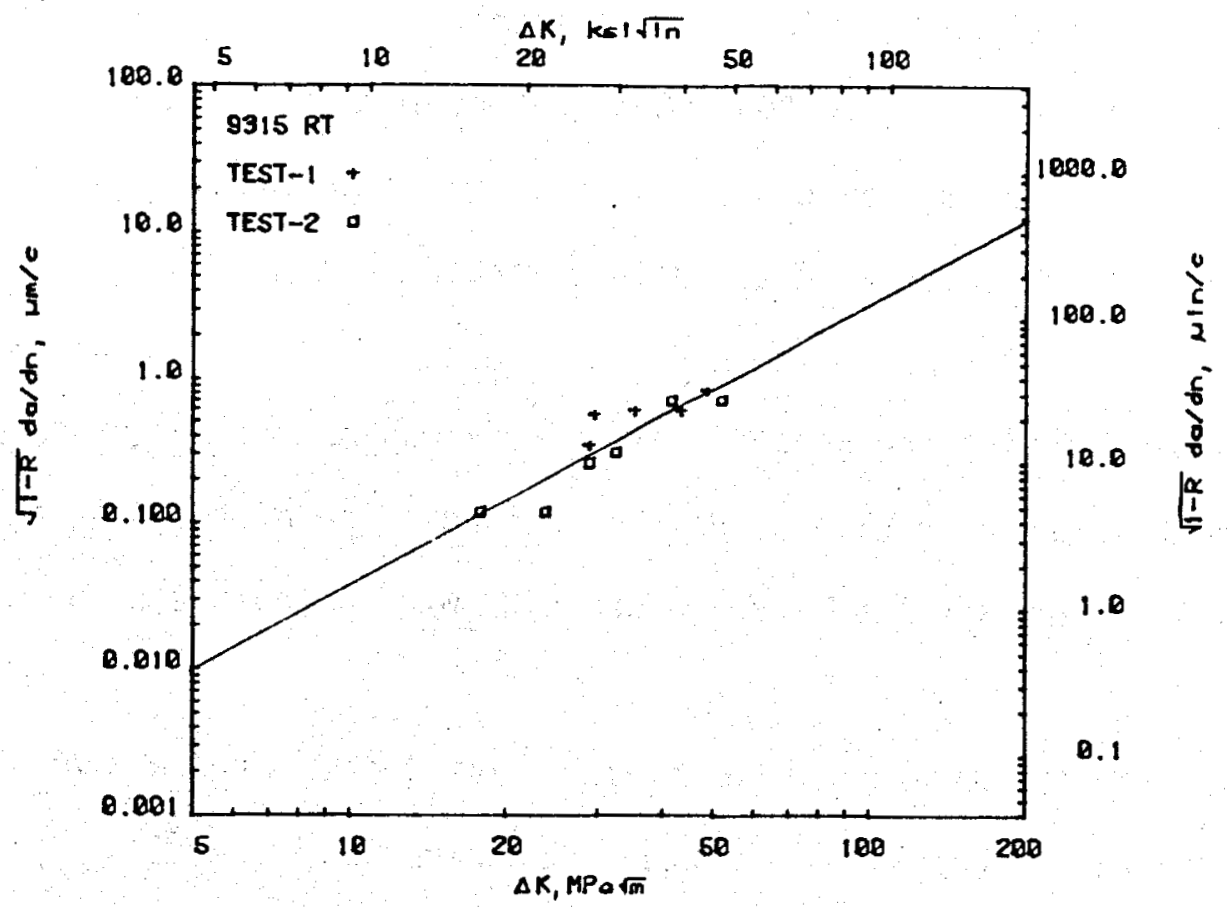

Figure 28. Crack growth rate as a function of stress intensity factor for AISI 9315. 
CBS 600: CBS 600 was tested at $300^{\circ} \mathrm{C}$, as were CBS $1000 \mathrm{M}$, EX-00053 and $\mathrm{X}-2 \mathrm{M}$. Although it is widely known that temperature affects crack propagation rates $^{16}$ it is not clear whether temperature changes the $m$ values or simply increases (or decreases) the crack propagation rate ${ }^{19}$. The tests of CBS 600 show a high degree of scatter in the data (see Figure 29 ) and the $m$ value of 4.9 is therefore somewhat arbitary. The $50.8 \mathrm{~mm}$ diameter cylinders tested in fatigue were from the same heat treatment that produced the $154 \mathrm{MPa} \sqrt{\mathrm{m}}$ room temperature static fracture toughness value. Although there were not enough $50.8 \mathrm{~mm}$ cylinders to test the static toughness at $300^{\circ} \mathrm{C}$ it is apparent that it drops rapidly, as evidenced by the 25.4 $\mathrm{mm}$ data and that the $65.4 \mathrm{MPa} \sqrt{\mathrm{m}} \mathrm{K}_{\max }$ value is approaching $\mathrm{K}_{\mathrm{Ic}}$ for the material. Crack closure was not a major problem with the lack of data at low crack growth rates. Longer testing at $\Delta K$ values near $20 \mathrm{MPa} \sqrt{\mathrm{m}}$ would help to clarify the fatigue behavior of this steel.

CBS 1000M: The two tests on CBS 1000M gave different results as shown in Figure 30 . The $m$ value of 3.2 for test number two may be more valid than the combined value of 2.4. Both cylinders were austenitized at $955^{\circ} \mathrm{C}$ and the $K_{I C}$ for $79.5 \mathrm{MPa} \sqrt{m}$ in the static test at $300^{\circ} \mathrm{C}$ was approached by the $K_{\max }$ of 70.4 during the second test. There was only minor crack closure observed in these specimens and the extrapolation of the data below a $\Delta K$ of $20 \mathrm{MPa} \sqrt{\mathrm{m}}$ is not advised since no crack growth was observed in this region.

EX-00053: No test data could be obtained for EX-00053 below a $\Delta K$ of $40 \mathrm{MPa} \sqrt{\mathrm{m}}$, so the extrapolation of the Tine shown in Figure 31 below a $\Delta K$ of $40 M P a \sqrt{m}$ is very arbitrary. The fact that all of the data 


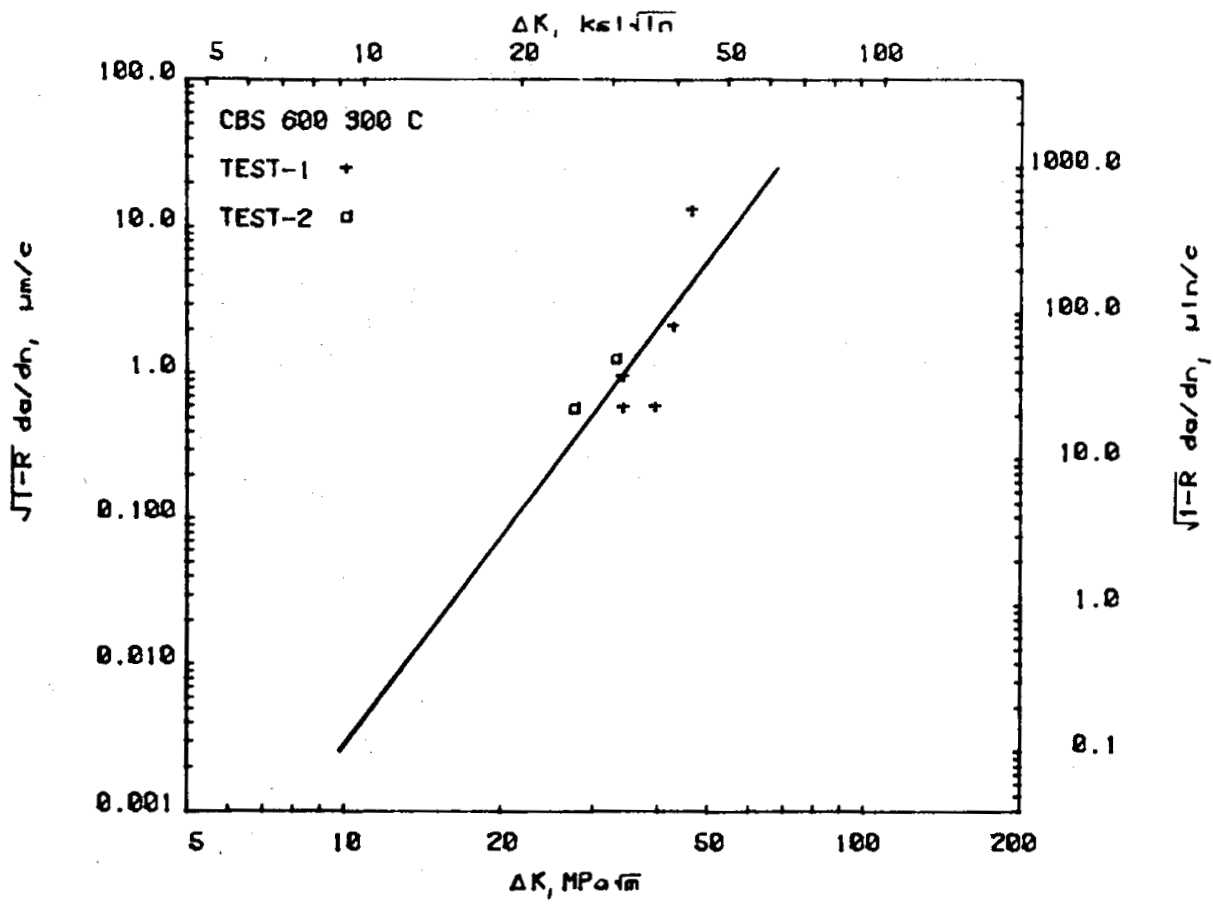

Figure 29. Crack growth rate as a function of stress intensity factor for CBS 600 .

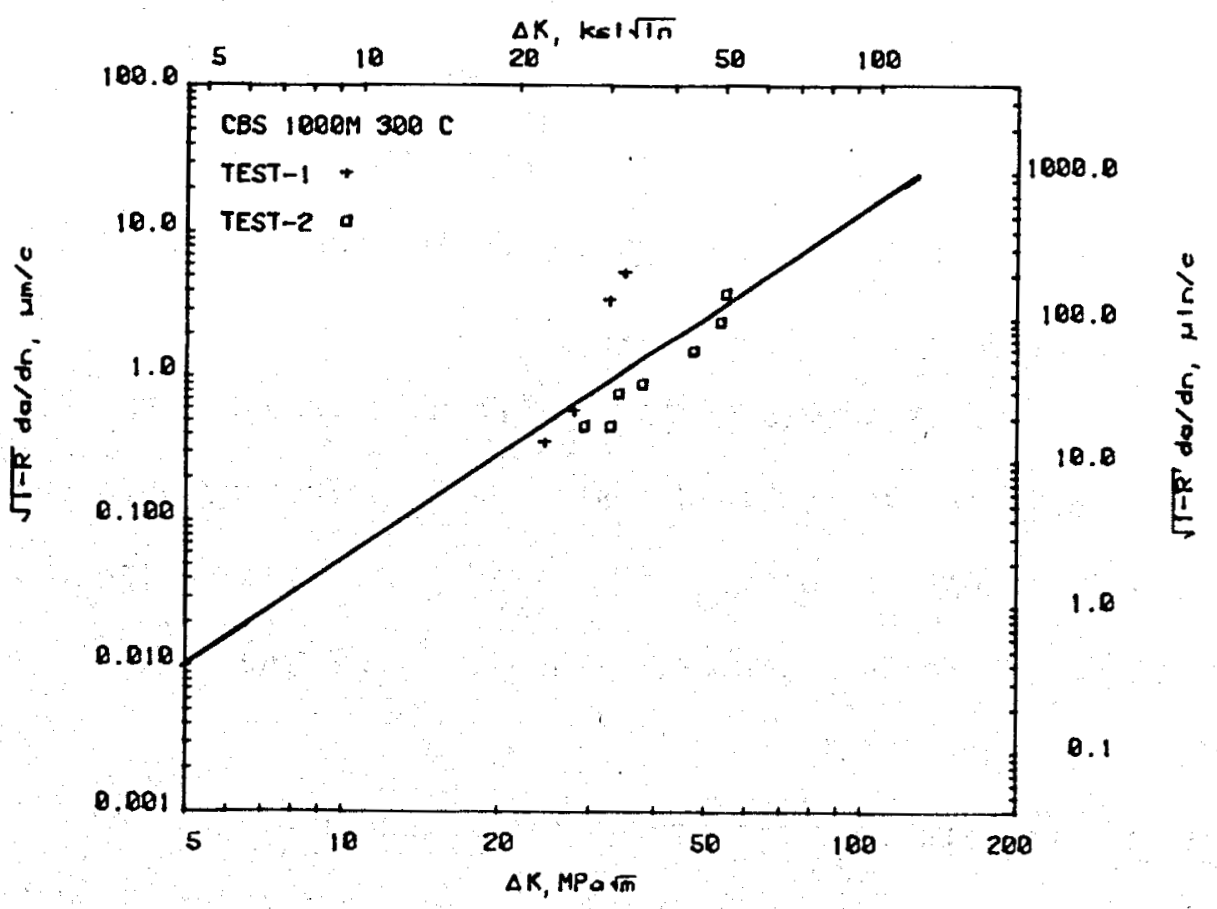

Figure 30. Crack growth rate as a function of stress intensity factor for CBS $1000 \mathrm{M}$. 


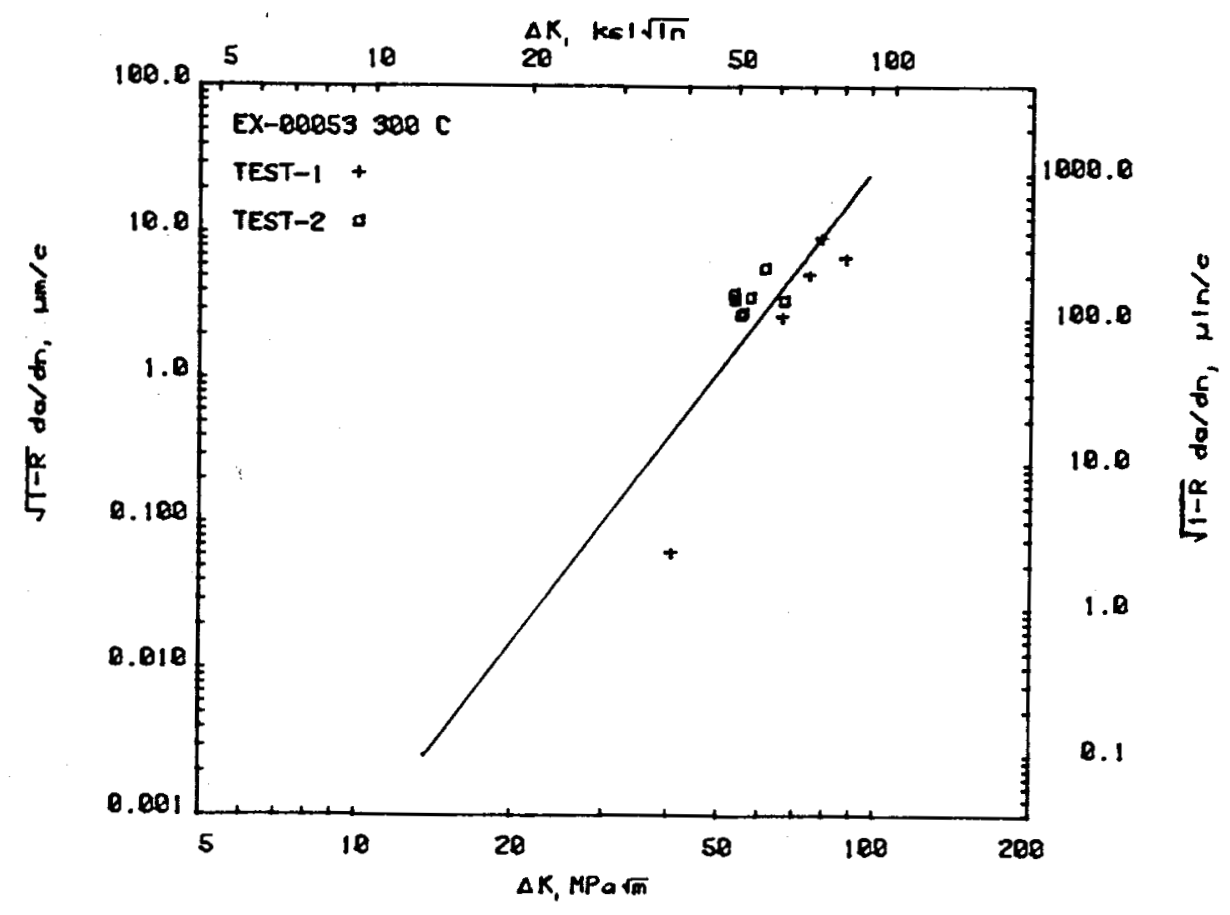

Figure 31. Crack growth rate as a function of stress intensity factor for EX-00053.

from the second test are clustered around $10 \mu \mathrm{m} / \mathrm{cycle}$ lowered the $\mathrm{m}$ value from the 6.6 observed in the first test to 4.7 . More test data could be obtained at $\Delta \mathrm{K}^{\prime} \mathrm{s}$ between 40 and $50 \mathrm{MPa} \sqrt{\mathrm{m}}$ if longer tests (several days) were conducted. Crack closure was not a problem during these tests due to the high fracture toughness of EX-00053 at $300^{\circ} \mathrm{C}$.

X-2M: Both tests on $X-2 M$ showed consistent results (see Figure 32) with an $m$ value of 6.0 for the combined tests. $K_{\max }$ values of 46.5 and 52.1 $\mathrm{MPa} \sqrt{\mathrm{m}}$ are about $75-80$ percent of the $\mathrm{K}_{\mathrm{Ic}}(63.5 \mathrm{MPa} \sqrt{\mathrm{m}})$ observed during the static tests at $300^{\circ} \mathrm{C}$. The data, however, are well within the region associated with stable crack growth.

Combined Data: The data from all of the tests are displayed in Figure 33. Although the data points for 8620 span the entire length of 


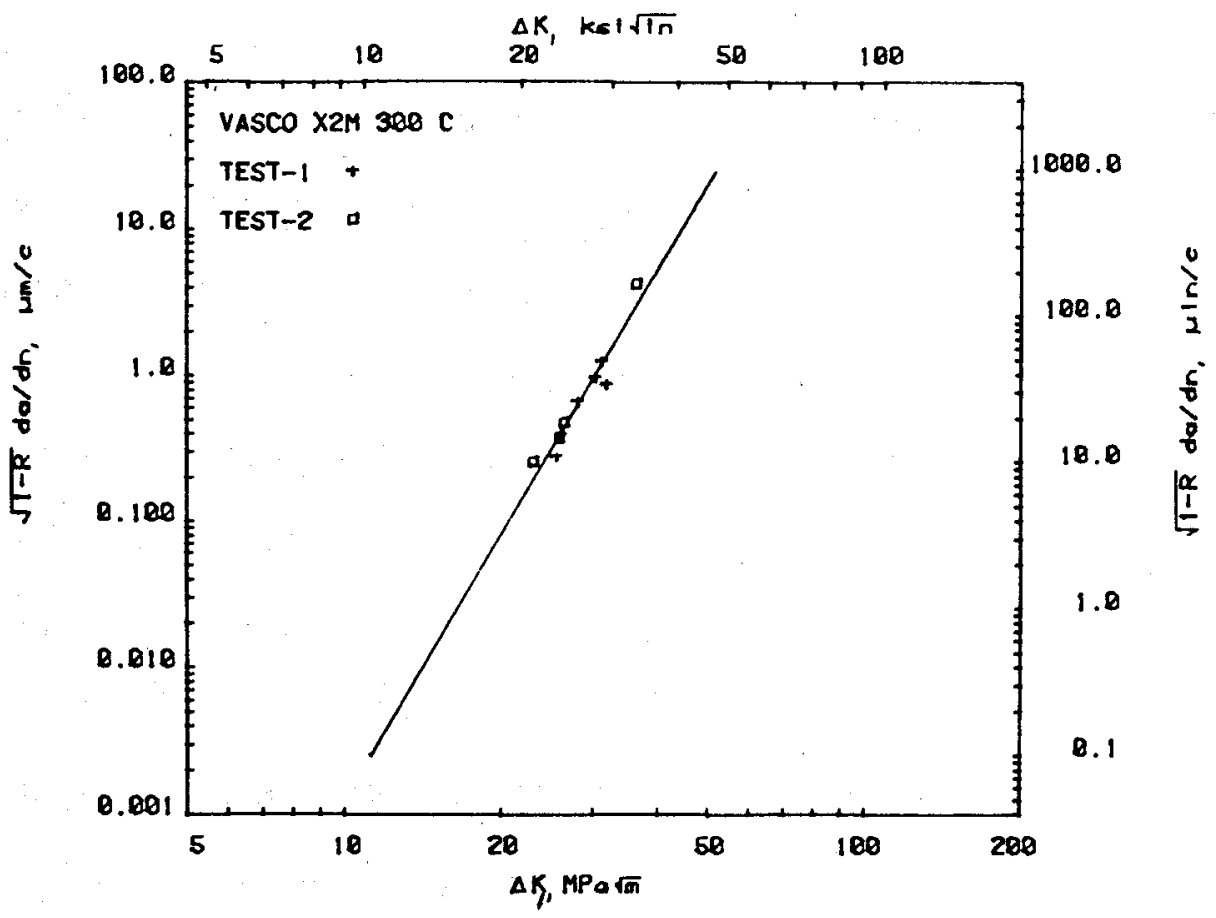

Figure 32. Crack growth rate as a function of stress intensity factor for $X-2 M$.

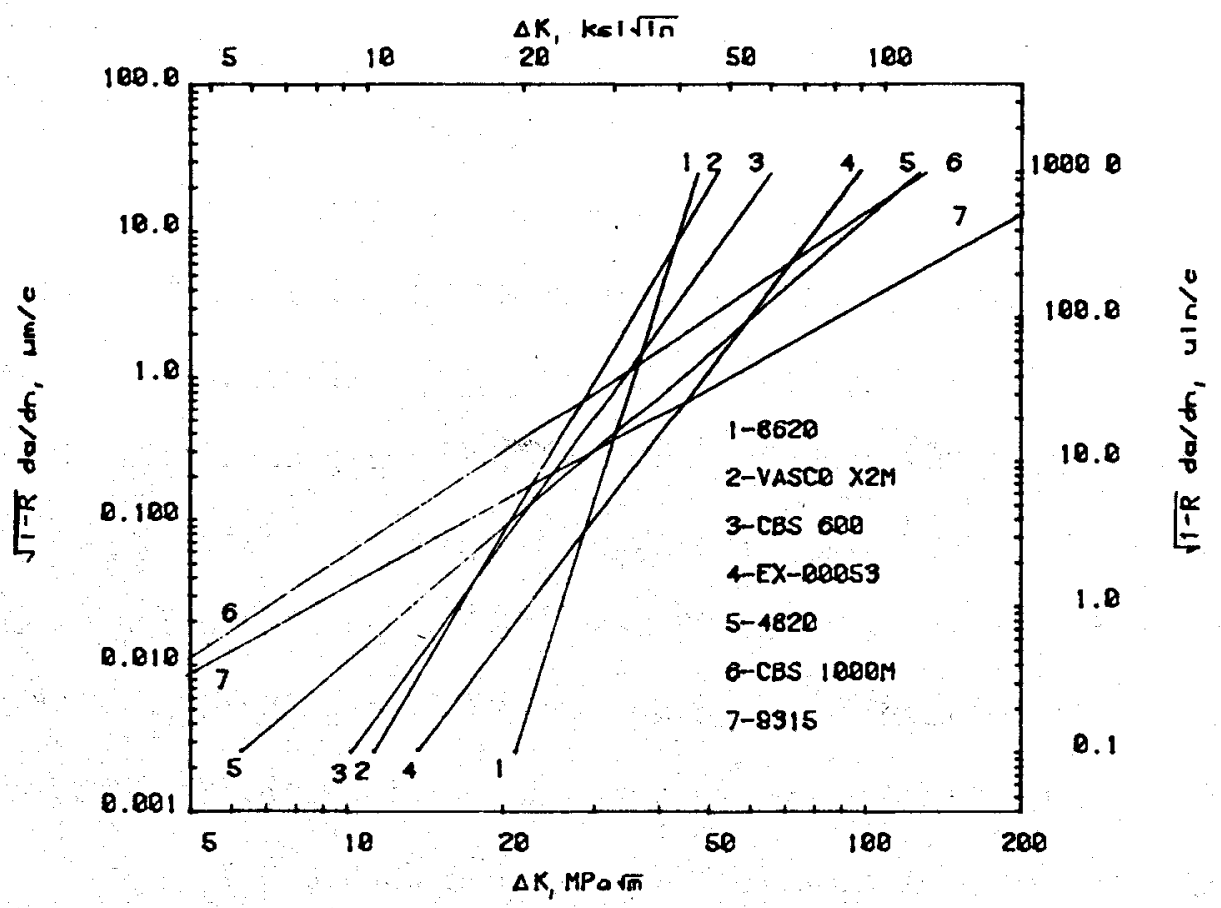

Figure 33. Crack growth rate as a function of stress intensity factor for all steels tested. (Note that 4820,8620 and 9315 were tested at $23^{\circ} \mathrm{C}$ while CBS $600, \mathrm{CBS} 1000 \mathrm{M}, \mathrm{EX}-00053$ and $\mathrm{X}-2 \mathrm{M}$ were tested at $300^{\circ} \mathrm{C}$. 
the line, it must be emphasized that the other lines are simply extrapolations from the data at low and high $\Delta K$ values. As has been previously discussed, the data may not form a straight line in these regions depending on where crack propagation begins and catastrophic failure starts.

Obviously, the best way to evaluate the data is to pick the $\Delta K$ range associated with geothermal or conventional drilling. Unfortunately, the $\Delta K$ range to which the bits are presently subjected is not known. An alternative method of evaluation would be to pick a crack growth rate, below the critical rate for catastrophic failure, and observe the $\Delta K$ at which the rate occurs in an individual steel. The latter approach is a better method for comparing the steels in the test program since a crack growth rate can be picked within the experimental data of all of the steels.

If the steels in Figure 33 are compared at a growth rate $(\sqrt{1-R} d a / d N)$ of $0.1 \mu \mathrm{m} / \mathrm{cycle}$, EX-00053 and 8620 would clearly have the highest $\Delta \mathrm{K}$ (30 $\mathrm{MPa} \sqrt{\mathrm{m}}$ ) while X-2M, CBS 600 and 4820 would be intermediate (20 MParm) and 9315 and CBS 1000M would display this growth rate at $\triangle K$ 's of approximately $15 \mathrm{MPa} \sqrt{\mathrm{m}}$. If, alternatively, the steels are compared at a growth rate of $1.0 \mu \mathrm{m} / \mathrm{cycle}$ then 9315 , EX-00053 and 4820 display the highest $\Delta K^{\prime} \mathrm{s}(40-50$ $M P a \sqrt{m}$ ) while $8620, C B S 1000 M$ and CBS 600 have the same growth rate at a $\triangle K$ of $35 \mathrm{MPa} \sqrt{\mathrm{m}}$ and $\mathrm{X}-2 \mathrm{M}$ at $30 \mathrm{MPa} \sqrt{\mathrm{m}}$. The $\Delta \mathrm{K}$ of interest is obviously critical since at a stress intensity level of $30 \mathrm{MPa} \sqrt{\mathrm{m}}, 8620$ and EX-00053 have crack growth rates an order of magnitude slower than 9315 and CBS 1000M. At a $\Delta K$ of $50 \mathrm{MPa} \sqrt{\mathrm{m}}$, however, the crack propagation rate in 9315, EX-00053 and 4820 is at least an order of magnitude slower than 8620 and $X-2 M$.

The data generated suggest a wide variation in the room-temperature fatigue behavior of 4820,8620 and 9315 which is not completely under- 
stood at this time. The $300^{\circ} \mathrm{C}$ fatigue crack resistance data for the high wear resistant steels are certainly within the scatter of the conventional steels at room temperature. It would appear that all of the steels will display adequate fatigue crack resistance when used at elevated temperature, based on the infrequent fatigue failures experienced by 4820,8620 and 9315 in dri11 bits. Based on the limited testing performed, EX-00053 appears to show improved fatigue crack resistance when compared to CBS 600 and X-2M. It would also appear that EX-00053 is superior to CBS $1000 \mathrm{M}$ at $\Delta K^{\prime}$ 's less than 78-80 MParm. 8620 is clearly superior to 9315 and 4820 at $\Delta K^{\prime}$ 's up to $30 \mathrm{MPa} \sqrt{\mathrm{m}}$ but 9315 and 4820 could only be used above $40 \mathrm{MPa} \sqrt{\mathrm{m}}$ since cracks in 8620 grow catastrophically above this stress intensity.

SEM micrographs displayed in Figures B19 through B32 (see Appendix B) compare the fracture surfaces of fatigued samples to their statically tested counterparts at a corresponding temperature. There were no major differences between the mode of fracture in the static fracture toughness tests and the fatigue crack resistance tests. All samples appear to have failed in a ductile mode caused by microvoid coalescence. Striations are normally not observed in martensitic structures ${ }^{19}$ and none were observed on the fractured surfaces of the fatigued samples. The dimples on static tests were consistently larger than the voids on the fatigued surfaces, confirming the much faster speed at which the fracture toughness measurements were made. The reason for the high $\mathrm{m}$ value for 8620 , in contrast to normal $m$ values for 4820 and 9315 , was not explained by the SEM micrographs. Further fatigue testing is needed to clarify the behavior and to quantify differences between the steels. 

CONCLUSIONS

1. Both conventional and high wear resistant steels displayed wide variations in fracture toughness over the temperature range $23^{\circ} \mathrm{C}$ to $400^{\circ} \mathrm{C}$. It is therefore important to characterize the fracture behavior of steels in the temperature range of operation.

2. Steels having microstructures of 100 percent tempered martensite (CBS 1000M, EX-00053, X-2M and 9315) displayed nearly constant or increasing toughness above room temperature, whereas steels containing mixed microstructures (4820, 8620 and CBS 600) decreased significantly in fracture toughness in the temperature range $23^{\circ} \mathrm{C}$ to $300^{\circ} \mathrm{C}$.

3. EX-00053 and CBS 1000M were the only steels tested which displayed significantly higher toughness than 9315 over the entire temperature range. 9315 was superior in toughness to 4820 and 8620 over the entire temperature range. In the temperature range normally encountered at the Geysers $\left(150-300^{\circ} \mathrm{C}\right)$, all of the steels tested have toughness at least equivalent to 4820 and 8620 . If accelerated bit rotation speeds and higher loads are applied to increase penetration rates, EX-00053 and CBS 1000M are the two steels most capable of withstanding greater impact loading.

4. EX-00053 and CBS 1000M displayed an increase in toughness between $23^{\circ} \mathrm{C}$ and $100^{\circ} \mathrm{C}$, associated with a brittle-to-ductile fracture transition. EX-00053 increased in toughness from $103.6 \mathrm{MPa} \sqrt{\mathrm{m}}$ at room temperature to $264.6 \mathrm{MPa} \sqrt{\mathrm{m}}$ at $100^{\circ} \mathrm{C}$.

5. Fatigue crack resistance measurements at $300^{\circ} \mathrm{C}$ for CBS 600, CBS $1000 \mathrm{M}$, EX-00053 and X-2M were well within the scatter in fatigue behavior 
observed for 4820,8620 and 9315 at room temperature. Although the fatigue data for these steels are limited to date, they suggest that all of the steels have enough fatigue crack resistance to withstand present geothermal drilling conditions. EX-00053 has superior fatigue crack resistance at $\Delta K^{\prime}$ 's less than $50 \mathrm{MPa} \sqrt{m}$ and appears to be the best candidate for use at $300^{\circ} \mathrm{C}$. 8620 displayed slower crack propagation rates at $\Delta \mathrm{K}^{\prime} \mathrm{s}$ less than $30 \mathrm{MPa} \sqrt{\mathrm{m}}$ when compared to 4820 and 9315 at room temperature, and 9315 is clearly superior above $50 \mathrm{MPa} \sqrt{\mathrm{m}}$.

6. Since bit failure is usually associated with wear, it would appear that studies of the hot hardness and wear resistance of these steels should be conducted on a comparable basis. A cost comparison, as well as fabrication considerations (heat treating, machinability, weldability, etc.) is also needed to determine the economic consequences of using high wear resistant steels to obtain improved penetration rates. 


\section{REFERENCES}

1. Hendrickson, R. R., S. J. Green, A. H. Jones, and R. W. Winzenried, "Full-Scale Laboratory Testing of Experimental Geothermal Rock Bits," Trans. Geothermal Resources Counci1, 2, p. 267, 1978.

2. Friedman, E. J. and A. E1-Sawy, "Prospects for Improvement in Geothermal Well Technology and Their Expected Benefits," HCP/T4014-04, UC-77c, Mitre Corp., McLean, Virginia, 1978.

3. Hendrickson, R. R., A. H. Jones, R. W. Winzenried, and A. B. Maish, "Field Drilling Tests on Improved Geothermal Unsealed Roller-Cone Bits," Terra Tek Report TR 79-57, 1979.

4. Barker, L. M. and W. C. Leslie, "Short Rod KIc Tests of Several Steels at Temperatures to $700^{\circ} \mathrm{K}$ ", Fracture 1977, ICF 4, Waterloo, Canada, p. $305,1977$.

5. Barker, L. M., "Evaluation of a Simple Method for Measuring Fracture Toughness," Eng. Frac. Mech., 9, p. 361, 1977.

6. Barker, L. M., "Short Rod Measurements of $\mathrm{Al}_{2} \mathrm{O}_{3}$," Fracture Mechanics of Canada, 3, edited by R. C. Bradt, D.P.H. Hasselman, and F. F. Lange, Plenum Publishing Co., p. 483, 1978.

7. Barker, L. M., "Theory for Determining KIC from Small, Non-LEFM Specimens, Supported by Experiments on Aluminum," Int. J. of Fracture, 15, 6, p. 515, 1979.

8. Barker, L. M. and F. I. Baratta, "Comparisons of Fracture Toughness Measurements by the Short Rod and ASTM Standard Method of Test for Plain Strain Fracture Toughness of Metallic Materials (E 399-78)", J. of Testing and Evaluation, 8, 3, p. 97, 1980.

9. Beech, J. F. and A. R. Ingraffea, "Three-Dimensional Finite Element Calibration of the Short Rod Specimen," Geotechnical Engineering Report 80-3, Cornell University, Ithaca, New York, 1980.

10. Barker, L. M. and R. V. Guest, "Compliance Calibration of the Short Rod Fracture Toughness Specimen," Terra Tek Report TR 78-20, 1978.

11. Guest, R. V., "Fracture Toughness Testing Using Short Rod Specimens, Illustrated by Controlled Temperature Tests on M-2 High Speed Tool Stee1," to appear in Proceedings of the Symposium on New Developments in Processing and Properties of High Speed Tool Steels, AIME Annual Meeting, Las Vegas, Nevada, February 24-28, 1980. Also, Terra Tek Report TR 80-38, 1980. 
12. Barker, L. M., "Residual Stress Effects on Fracture Toughness Measurements," Terra Tek Report TR 80-37, 1980.

13. Shin, T. T. and R. P. Wei, "A Study of Crack Closure in Fatigue," Eng. Frac. Mech., 6, 19, 1974.

14. Paris, P. C., "The Fracture Mechanics Approach to Fatigue," Proc. 10th Sagamore Conference, Syracuse University Press.

15. Hudson, C. M. and H. F. Hardrath, "Effects of Changing Stress Amplitude on the Rate of Fatigue Crack Propagation in Two Aluminum Alloys," NASA TN D 960, 1961.

16. Sosie, D. F., M. R. Mitche11, and E. M. Caulfield," Fundamentals of Modern Fatigue Analysis," Fracture Control Program Report 26, University of Illinois, 1978.

17. Jatczak, C. F., Private communication with R. Cutler, 1980.

18. Hudson, M. and C. Seward, "Compendium of Sources of Fracture Toughness and Fatigue-Crack Growth Rate for Metallic Alloys," Int. J. of Fracture, 14, 1978.

19. Richards, C. E. and T. C. Lindley, "The Influence of Stress Intensity and Microstructure on Fatigue Crack Propagation in Ferritic Materials," Eng. Frac. Mech., 2, p. 951, 1972.

20. Bucci, R. J., W. G. Clark, and P. C. Paris, "Fatigue Crack Propagation Rates under a Wide Variation of $\triangle K$ for an ASTM A517 Grade $F(T-1)$ Steel," Stress Analysis and Growth of Cracks, Proceedings of the 1971 National Symposium on Fracture Mechanics, Part 1, ASTM STP 513, p. $177,1972$. 


\section{ACKNOWLEDGMENTS}

The authors wish to express their appreciation to Daniel Van Rooyen of Brookhaven National Laboratory and the Department of Energy for supporting this research. Steel for the program was provided by Carpenter Technology, Timken Company and Teledyne/Vasco. Deep appreciation is expressed to Chester Jatczak, Walter Burd and Richard Henry for discussions concerning heat treatments and experimental results.

Chemical analyses, SEM fractographic analyses and microstructure determinations were performed by Ronald McAlpin of Radian Corporation. Appreciation is expressed to Barbara Mueller of DOE/DGE, Chicago Operations Program, for making this characterization possible.

This research would not have been possible without the excellent developmental work on the short-rod technique by Lynn Barker of Terra Tek. The direction and help of Lynn Barker and Michael Wilson of Terra Tek is gratefully acknowledged. Professor J. G. Bryne of the University of Utah also provided insight into the work. 

APPENDIX A

HEAT TREATMENTS AND $K_{\text {IC }}$ DATA

59 


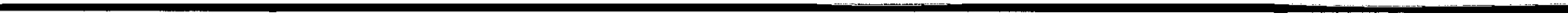


TABLE A1

Brookhaven Geothermal Materials Contract Fracture Toughness Data

\begin{tabular}{|c|c|c|c|c|c|c|c|c|}
\hline \multirow[b]{2}{*}{ Steel Type } & \multirow[b]{2}{*}{$\begin{array}{l}\text { Manufacturer's } \\
\text { Code }\end{array}$} & \multirow{2}{*}{$\begin{array}{c}\text { Heat } \\
\text { Treatment } \\
\text { (see attached shee1) }\end{array}$} & \multirow{2}{*}{$\begin{array}{l}\text { Cylinder } \\
\text { niareter: } \\
\text { (inctris: }\end{array}$} & \multicolumn{5}{|c|}{$k_{\text {IC SR }}\left(k_{5 i}\right.$ in) } \\
\hline & & & & $R T$ & $100 \mathrm{c}$ & $200^{\circ} \mathrm{C}$ & $30 n \mathrm{C}$ & $400^{\circ} \mathrm{C}$ \\
\hline 4820 & - & A & 2 & $\left\{\begin{array}{c}86.9 \cdot 13.3 \\
{[15.4)} \\
{[5 \text { tests }]}\end{array}\right.$ & 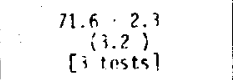 & $\begin{array}{c}52.0 \cdot 7 i^{1} \\
{[13 \text { tests] }}\end{array}$ & $\begin{array}{l}61.4 \cdot 1.4 \\
{[3 \text { tests }]}\end{array}$ & -. \\
\hline 8620 & -- & B & 2 & $\begin{array}{c}102.3 .18 .7 \\
(18.7) \\
{[4 \text { tests }]}\end{array}$ & 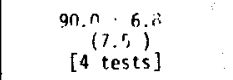 & $\begin{array}{r}67.0 .1 j^{2} \\
{[1.8)^{2}} \\
{[3 \text { tests }]}\end{array}$ & $\begin{array}{l}62.8 \cdot 9.8 \\
{[15.6)^{2}} \\
{[4 \text { tests }]}\end{array}$ & -- \\
\hline 9315 & -- & $c$ & 1 & $\mid \begin{array}{c}109.8 \cdot 3.4 \\
{\left[3.1^{1} j\right.} \\
{[3 \text { tests }]}\end{array}$ & 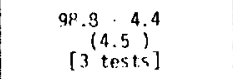 & $\begin{array}{c}86.8 \cdot 4.4 \\
(5.0 .4 \\
{[3 \text { tests] }}\end{array}$ & $\begin{array}{l}80.0 \cdot 2.7 \\
(3.4) \\
{[4 \text { tests }]}\end{array}$ & $\begin{array}{l}86.5 .51 .0 \\
(1.23) \\
{\left[3^{3} \text { tests }\right]}\end{array}$ \\
\hline $\operatorname{CBS} 600$ & 3 & 0 & ? & {$\left[\begin{array}{r}140.1 \\
(1.2)^{6} \\
{[2 \text { tests }]}\end{array}\right.$} & -. & -- & -- & -- \\
\hline CBS 600 & 600 & n & 1 & $\begin{array}{l}94.1: 1.6 \\
{\left[\begin{array}{l}\left(1.7 j^{6}\right. \\
2 \text { tests }]\end{array}\right.}\end{array}$ & $\begin{array}{l}(7.8 \cdot n .5 \\
(2 \text { tests }]\end{array}$ & $\begin{array}{c}55.9 \cdot 2^{2} j^{3} \\
(2 \text { tests }]\end{array}$ & $\begin{array}{r}53.4 \cdot 1.1 \\
(2.0) j^{1} \\
{[2 \text { tests }]}\end{array}$ & $\begin{array}{c}65.2 \cdot 0.8 \\
(1.3 x) \\
{[2 \text { tests }]}\end{array}$ \\
\hline CBS $600 \mathrm{M}$ & 671 & [ & 1 & $\begin{array}{l}63.1+2^{2.9} \\
\left(4.5^{2}\right)^{-} \\
{[3 \text { tests }]}\end{array}$ & -. & -- & -- & $\cdots$ \\
\hline CBS $600 M$ & 672 & $\mathrm{f}$ & 1 & $\begin{array}{l}\left.63.3 \cdot{ }^{2}\right)^{3} \\
{[3.6)^{2}} \\
{[3 \text { tests }]}\end{array}$ & . $\quad-\cdot$ & $-\cdot$ & -. & $\cdots$ \\
\hline CBS 600 & 4 & $r$ & $?$ & $\begin{array}{r}101.3 \cdot 1.9 \\
(1.9)^{9} \\
{[3 \text { tents }]}\end{array}$ & $\cdot$ & - & $\begin{array}{c}79.0,0.0 \\
(0.0 \%) \\
{[2 \text { tests }]}\end{array}$ & -- \\
\hline CBS $1000 M$ & 1 & $G$ & ? & $\begin{array}{c}51.9 \cdot n .8 \\
(1.5)^{8} \\
{[2 \text { tests }]}\end{array}$ & $\cdots$ & -. & {$\left[\begin{array}{c}72.3 \\
1 \text { test }]\end{array}\right.$} & -- \\
\hline CBS 1000M & 2 & 11 & ? & $\begin{array}{c}40.9 \cdot 4: 1 \\
{\left[\begin{array}{c}10.0 \\
2 \\
\text { tests }\end{array}\right]}\end{array}$ & $\begin{array}{r}44.2 \cdot 3)^{3} \\
(2.5)^{2} \text { tests }\end{array}$ & $\cdots$ & {$\left[\begin{array}{c}51.1 \\
1 \text { test }]\end{array}\right.$} & -- \\
\hline CBS $1000 \mathrm{M}$ & $1000-2$ & 1 & 1 & 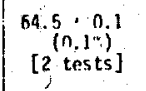 & $\begin{array}{r}114.4 .66^{7} \\
\left(5.9^{\circ}{ }^{7}\right. \\
{[2 \text { tests }]}\end{array}$ & $\begin{array}{c}96.05: 0^{3.9} \\
(4.1 \%) \\
2 \text { tests }]\end{array}$ & $\begin{array}{l}92.7 \quad 11.7 \\
{[2 \text { tests }]}\end{array}$ & $\begin{array}{l}97.5 .10 .7 \\
(0.7 x) \\
{[2 \text { tests }]}\end{array}$ \\
\hline CBS $1000 M$ & $3 A$ & i: & 1 & 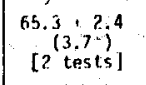 & $\begin{array}{r}103.2 \cdot 5.9 \\
{[2 \text { tests }]}\end{array}$ & $\begin{array}{l}92.1 \cdot 2.1 \\
\left(2.3^{3}\right)^{2} \\
{[2 \text { tests }]}\end{array}$ & $\begin{array}{r}82.9+2.6 \\
\left(3.2^{2}\right)^{6} \\
{[2 \text { tests] }}\end{array}$ & .. \\
\hline CBS $100 \mathrm{MM}$ & $3 \mathrm{~B}$ & h & 1 & $\begin{array}{l}56.100 .1 \\
(2 \text { tests }]\end{array}$ & 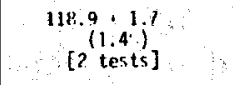 & $\begin{array}{r}136.5 \cdot 3,7 \\
(3,2 \%) \\
{[2 \operatorname{tests}]}\end{array}$ & 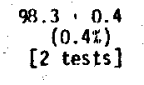 & -- \\
\hline EX-00053 & $\ldots$ & 1 & 2 & $\begin{array}{c}94.2 \cdot 7.5 \\
(8.0)^{5} \\
{[? \text { tests }]}\end{array}$ & $\begin{array}{l}240.5 \\
\text { [2nd test was } 268.5 \\
\text { but was invalid-. } \\
\text { too wuch plasticity] }\end{array}$ & $\begin{array}{l}201.2+{ }^{2} \cdot 1 \\
{[2 \text { tests }]}\end{array}$ & $\begin{array}{c}152.9 \cdot 3.3 \\
(2.1 \%) \\
{[2 \text { tests }]}\end{array}$ & {$\left[\begin{array}{l}1 \text { [ test gave } 185.2 \\
\text { but was thvalid.- } \\
\text { too much plasticity] }\end{array}\right.$} \\
\hline VASCO $X-2 M$ & - & 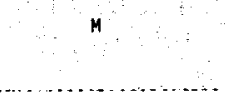 & 2 & $\begin{array}{l}43.7,21 \\
(4: 9) \\
{[2 \text { tests] }}\end{array}$ & 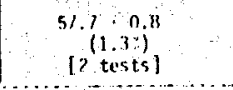 & $\left.\begin{array}{c}60.7 \cdot 1.3 \\
\left(2.2^{2}\right) \\
2 \text { tests }]\end{array}\right]$ & $\begin{array}{c}57.7 \cdot 2.7 \\
{[4.7,)^{2}} \\
{[2 \text { tests }]}\end{array}$ & $\begin{array}{r}55.0 \pm 1.5 \\
(2.7 \%)^{5} \\
{[2 \text { tests] }}\end{array}$ \\
\hline
\end{tabular}




\section{HEAT TREATMENTS}

Code

\section{Procedure}

A 1. Pseudo carburized in stainless steel envelope for seven hours at $1700^{\circ} \mathrm{F}\left(925^{\circ} \mathrm{C}\right)$. Air cooled.

2. Austenitized at $1525^{\circ} \mathrm{F}\left(830^{\circ} \mathrm{C}\right)$ for one hour. Water quenched with rigorous agitation.

3. Immediately tempered at $450^{\circ} \mathrm{F}\left(230^{\circ} \mathrm{C}\right)$ for two hours.

B 1. Pseudo carburized in stainless steel envelope for seven hours at $1700^{\circ} \mathrm{F}\left(925^{\circ} \mathrm{C}\right)$. Air cooled.

2. Austenitized at $1560^{\circ} \mathrm{F}\left(850^{\circ} \mathrm{C}\right)$ for one hour. Water quenched with rigorous agitation.

3. Immediately tempered at $450^{\circ} \mathrm{F}\left(230^{\circ} \mathrm{C}\right)$ for two hours.

C 1. Pseudo carburized for seven hours at $1700^{\circ} \mathrm{F}\left(925^{\circ} \mathrm{C}\right)$ in stainless steel envelope and oil quenched after withdrawal from envelope.

2. Reheated to $1500^{\circ} \mathrm{F}\left(815^{\circ} \mathrm{C}\right)$ and held for 30 minutes. 0 il quenched.

3. Double tempered at $350^{\circ} \mathrm{F}\left(175^{\circ} \mathrm{C}\right)$ for two hours each cycle.

D 1. Pseudo carburized for seven hours at $1700^{\circ} \mathrm{F}\left(925^{\circ} \mathrm{C}\right)$ in stainless steel envelope and oil quenched after withdrawal from envelope.

2. Conditioned at $1200^{\circ} \mathrm{F}\left(650^{\circ} \mathrm{C}\right)$ for two hours .

3. Reheated in salt to $1535^{\circ} \mathrm{F}\left(835^{\circ} \mathrm{C}\right)$, held 25 minutes $(1+30 \mathrm{~min}$. total time) and oil quenched with vigorous agitation.

4. Double tempered at $600^{\circ} \mathrm{F}\left(315^{\circ} \mathrm{C}\right)$ for two hours each cycle.

E 1. Pseudo carburized seven hours at $1700^{\circ} \mathrm{F}\left(925^{\circ} \mathrm{C}\right)$ in stainless steel envelope and oil quenched after withdrawal from envelope.

2. Conditioned at $1200^{\circ} \mathrm{F}\left(650^{\circ} \mathrm{C}\right)$ for four hours.

3. Reheated to $1550^{\circ} \mathrm{F}\left(845^{\circ} \mathrm{C}\right)$ and held for 30 minutes. $0 i 1$ quenched.

4. Cold treated at $-120^{\circ} \mathrm{F}\left(-85^{\circ} \mathrm{C}\right)$ for two hours.

5. Double tempered at $600^{\circ} \mathrm{F}\left(315^{\circ} \mathrm{C}\right)$ for two hours each cycle.

F 1. Pseudo carburized for seven hours at $1700^{\circ} \mathrm{F}\left(925^{\circ} \mathrm{C}\right)$ in stainless steel envelope and oil quenched after withdrawal from envelope.

2. Conditioned at $1200^{\circ} \mathrm{F}\left(650^{\circ} \mathrm{F}\right)$ for two hours.

3. Reheated in salt to $1600^{\circ} \mathrm{F}\left(870^{\circ} \mathrm{C}\right)$ and held 25 minutes $(1+30 \mathrm{~min}$. total time). 0il quenched with vigorous agitation.

4. Double tempered at $600^{\circ} \mathrm{F}\left(315^{\circ} \mathrm{C}\right)$ for two hours each cycle.

G 1. Preoxidized at $1700^{\circ} \mathrm{F}\left(925^{\circ} \mathrm{C}\right)$ for 0.5 hour.

2. Pseudo carburized for seven hours at $1700^{\circ} \mathrm{F}\left(925^{\circ} \mathrm{C}\right)$ in stainless steel envelope and oil quenched after withdrawal from envelope.

3. Conditioned at $1200^{\circ} \mathrm{F}\left(650^{\circ} \mathrm{C}\right)$ for two hours.

4. Reheated to $1750^{\circ} \mathrm{F}\left(955^{\circ} \mathrm{C}\right)$ for 25 minutes at heat $(1+45$ total time) in a stainless steel wrap and oil quenched.

5. Cold treated at $-120^{\circ} \mathrm{F}\left(-84^{\circ} \mathrm{C}\right)$ for three hours.

6 . Double tempered at $600^{\circ} \mathrm{F}\left(315^{\circ} \mathrm{C}\right)$ for two hours each cycle. 
APPENDIX B

SEM MICROGRAPHS 

H 1. Preoxidized at $1700^{\circ} \mathrm{F}\left(925^{\circ} \mathrm{C}\right)$ for 0.5 hours.

2. Pseudo carburized for seven hours at $1700^{\circ} \mathrm{F}\left(925^{\circ} \mathrm{C}\right)$ in stainiess steel envelope and oil quenched after withdrawal from envelope.

3. Conditioned at $1200^{\circ} \mathrm{F}\left(650^{\circ} \mathrm{C}\right)$ for two hours.

4. Reheated in individual stainless wrap to $1550^{\circ} \mathrm{F}\left(815^{\circ} \mathrm{C}\right)$ for 30 minutes at heat, then heated to $2000^{\circ} \mathrm{F}\left(1090^{\circ} \mathrm{C}\right)$ and held for 10 minutes. $0 i 1$ quenched.

5. Stress relieved at $700^{\circ} \mathrm{F}\left(370^{\circ} \mathrm{C}\right)$ for one hour.

6. Triple tempered at $7000^{\circ} \mathrm{F}\left(535^{\circ} \mathrm{C}\right)$ for two hours each cycle.

I 1. Pseudo carburized at $1700^{\circ} \mathrm{F}\left(925^{\circ} \mathrm{C}\right)$ in stainless steel envelope and oil quenched after withdrawal from envelope.

2. Reheated to $1750^{\circ} \mathrm{F}\left(955^{\circ} \mathrm{C}\right)$ and held for 30 minutes. $0 i 1$ quenched.

3. Cold treated at $-120^{\circ} \mathrm{F}\left(-85^{\circ} \mathrm{C}\right)$ for two hours.

4. Double tempered at $600^{\circ} \mathrm{F}\left(315^{\circ} \mathrm{C}\right)$ for two hours each cycle.

$\mathrm{J} \quad$ 1. Pseudo carburized at $1700^{\circ} \mathrm{F}\left(925^{\circ} \mathrm{C}\right)$ in stainless steel envelope and oil quenched after withdrawal from envelope.

2. Conditioned at $1200^{\circ} \mathrm{F}\left(650^{\circ} \mathrm{C}\right)$ for four hours.

3. Reheated to $1675^{\circ} \mathrm{F}\left(915^{\circ} \mathrm{C}\right)$ and held for 30 minutes.

4. Cold treated at $-120^{\circ} \mathrm{F}\left(-85^{\circ} \mathrm{C}\right)$ for two hours.

5. Double tempered at $600^{\circ} \mathrm{F}\left(375^{\circ} \mathrm{C}\right)$ for two hours each cycle.

K. Same as $\mathrm{J}$ except tempered at $800^{\circ} \mathrm{F}\left(425^{\circ} \mathrm{C}\right)$ for two hours each cycle.

L. 1. Pseudo carburized in stainless steel envelope for seven hours at $1700^{\circ} \mathrm{F}\left(925^{\circ} \mathrm{C}\right)$. Air cooled.

2. Austenitized at $1675^{\circ} \mathrm{F}\left(910^{\circ} \mathrm{C}\right)$ for one hour. $0 i 1$ quenched with rigorous agitation.

3. Tempered at $800^{\circ} \mathrm{F}\left(425^{\circ} \mathrm{C}\right)$ for one hour.

M. 1. Pseudo carburized in stainless steel envelope for two hours at $1850^{\circ} \mathrm{F}\left(1010^{\circ} \mathrm{C}\right)$. Air cooled.

2. Austenitized at $2050^{\circ} \mathrm{F}\left(1720^{\circ} \mathrm{C}\right)$ for 20 minutes. Air cooled.

3. Double tempered at $600^{\circ} \mathrm{F}\left(315^{\circ} \mathrm{C}\right)$ for two hours each cycle. 


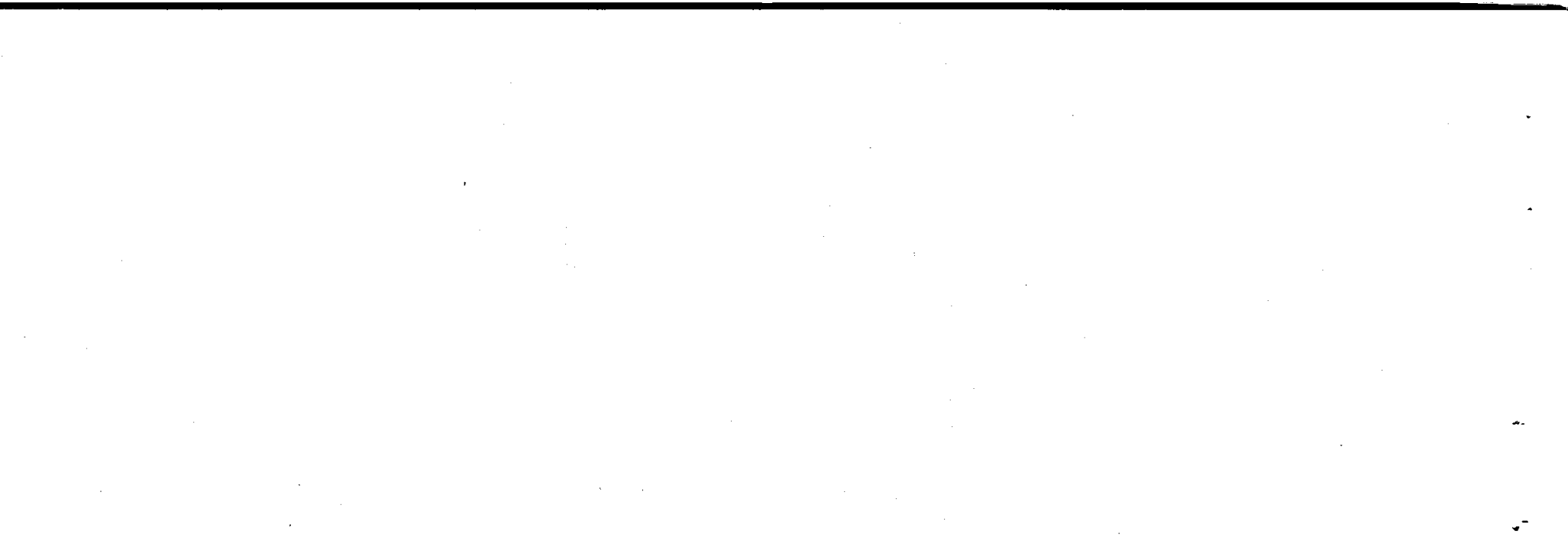




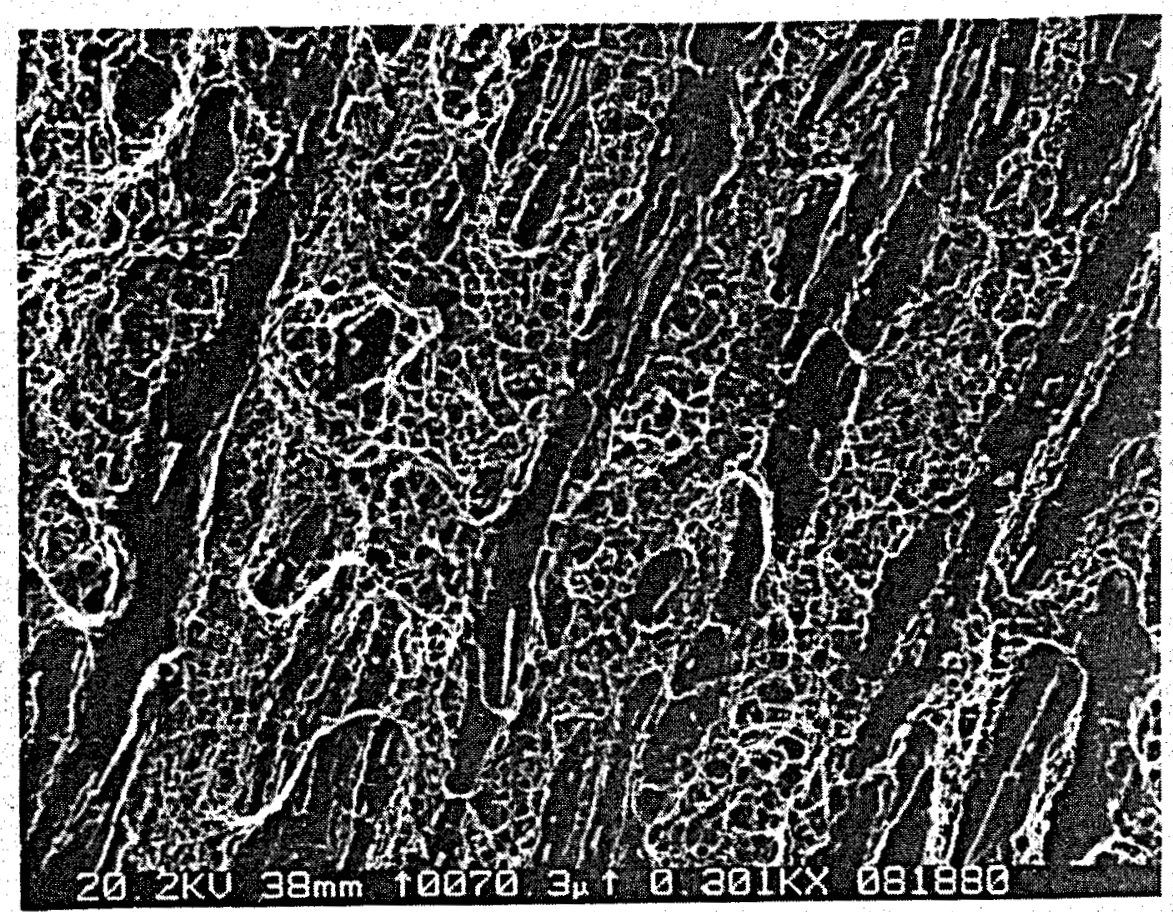

Figure B1. AISI 4820. Room Temperature Static Test. Ductile Fracture $(300 \mathrm{X})$.

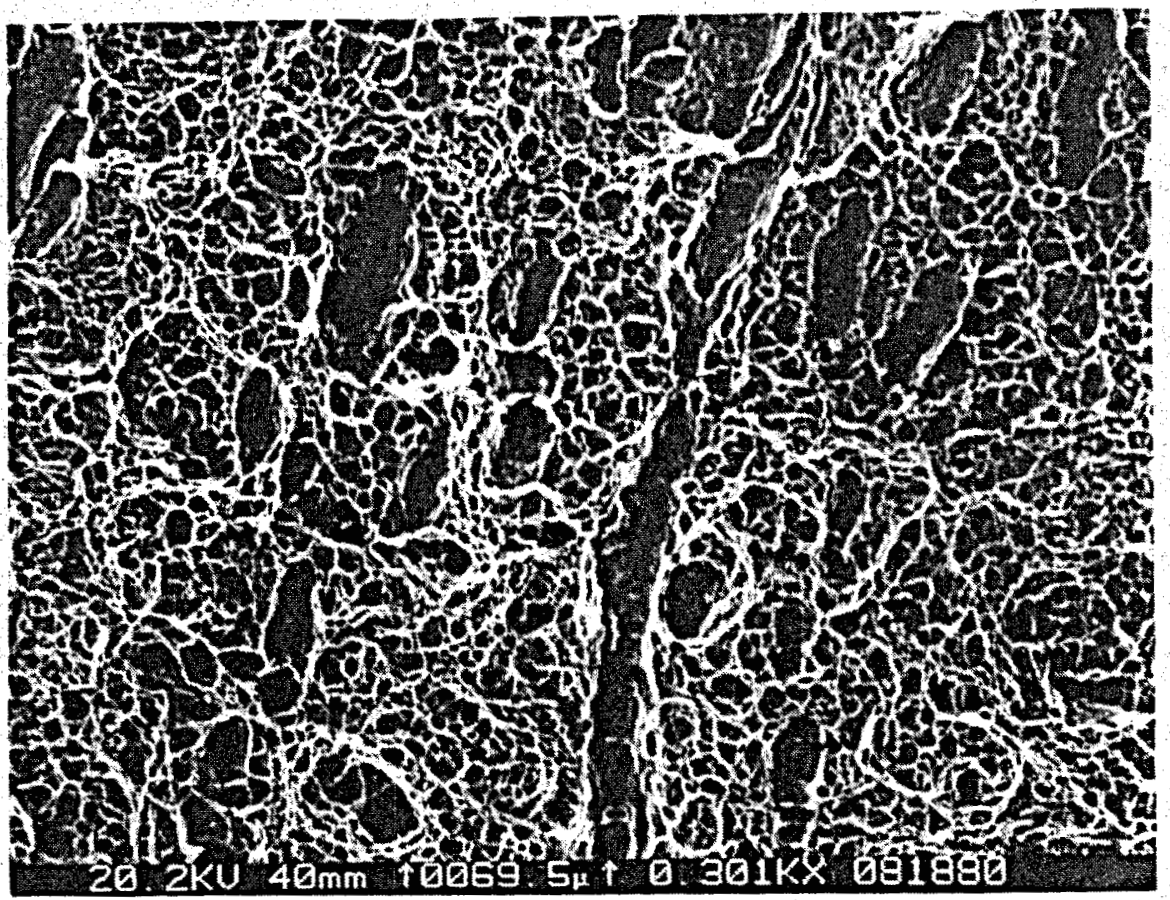

Figure B2. AISI $4820,300^{\circ} \mathrm{C}$ Static Test. Ductile Fracture $(300 \mathrm{X})$. 


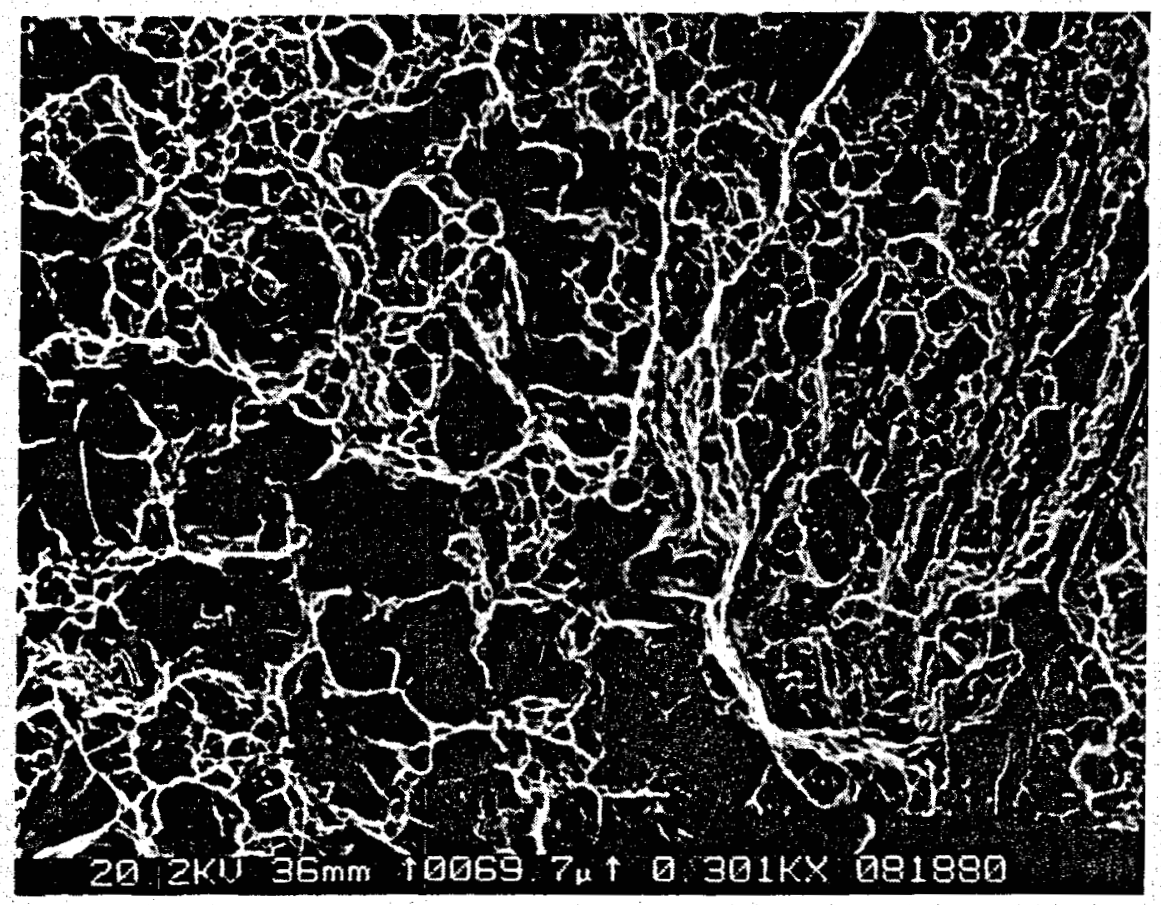

Figure B3. AISI 8620. Room Temperature Static Test. 25-75\% Brittle Cleavage (300X).

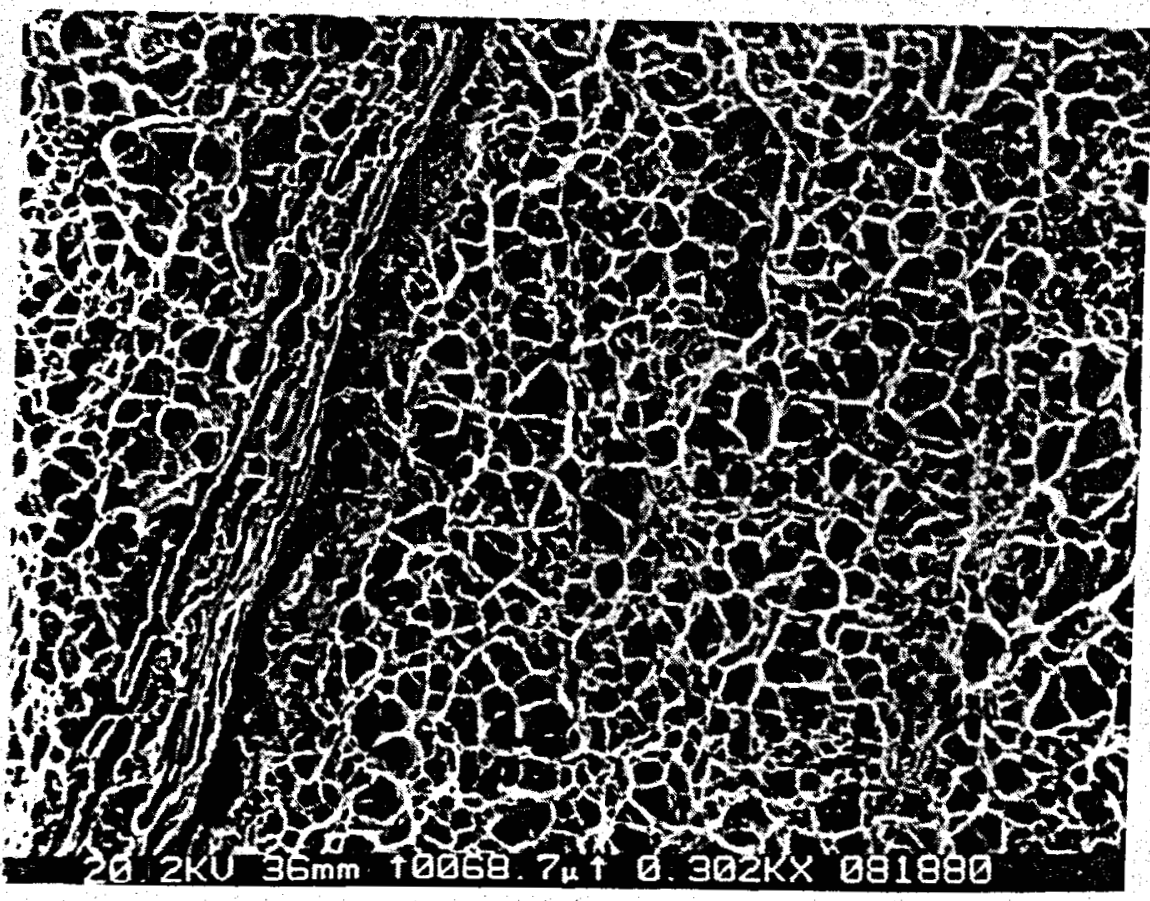

Figure B4. AISI $8620,300^{\circ} \mathrm{C}$ Static Test. Ductile Fracture $(300 x)$. 


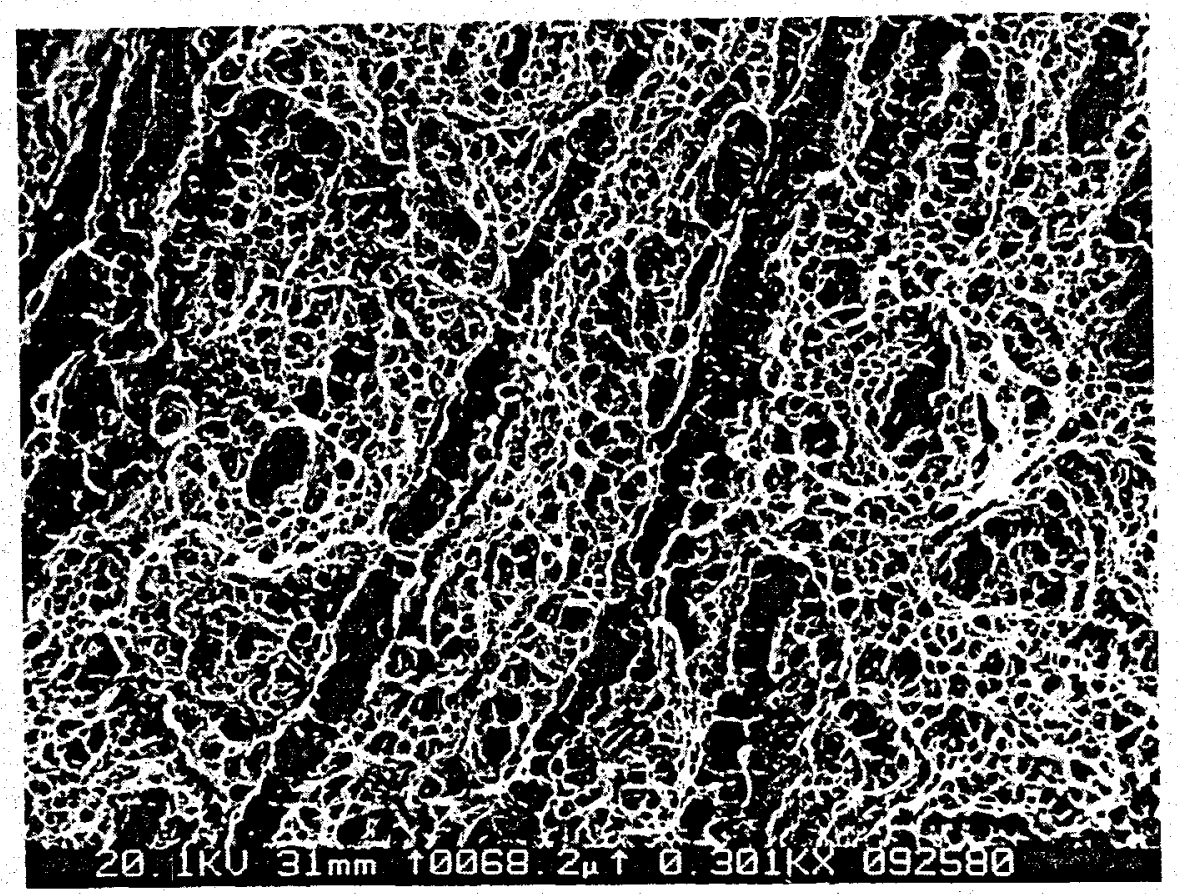

Figure B5. AISI 9315. Room Temperature Static Test. Ductile Fracture (300X).

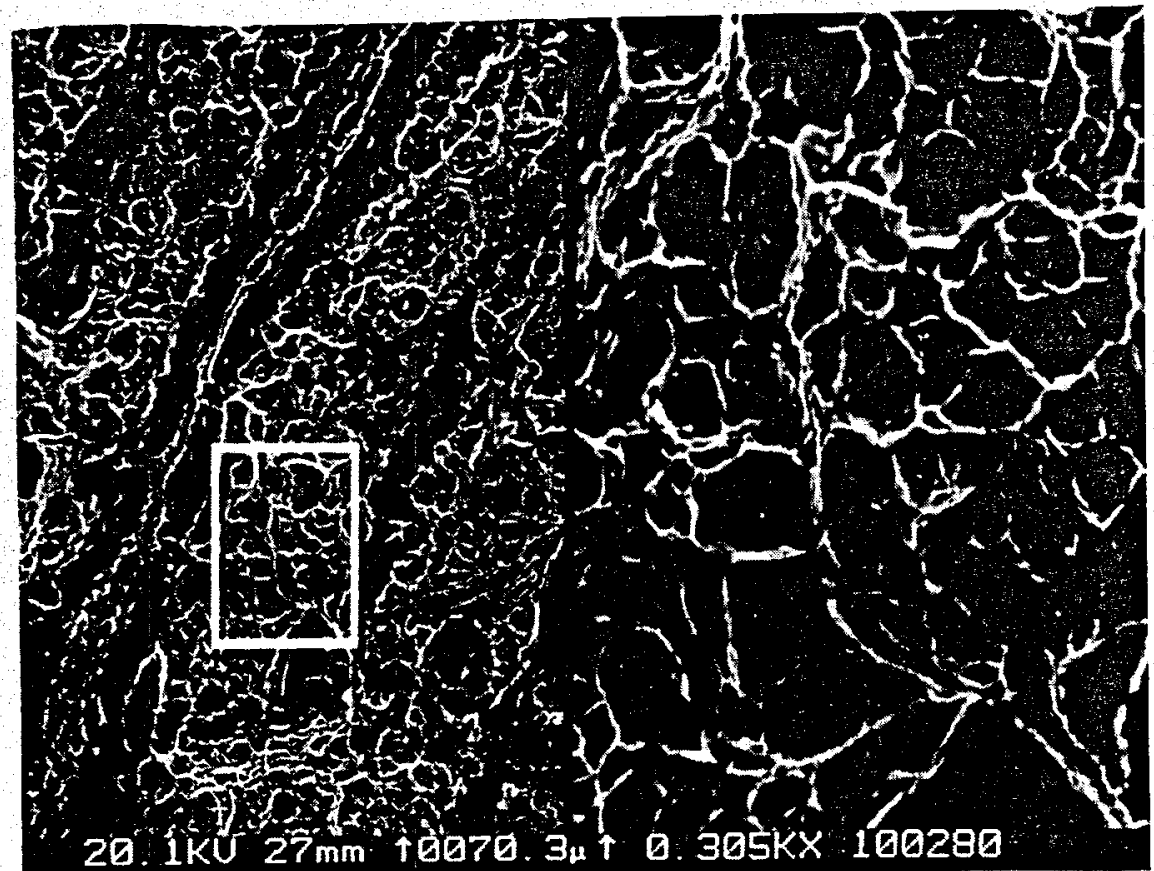

Figure B6. AISI $9315,100^{\circ} \mathrm{C}$ Static Test. Ductile Fracture $(300-1200 \mathrm{X})$. 


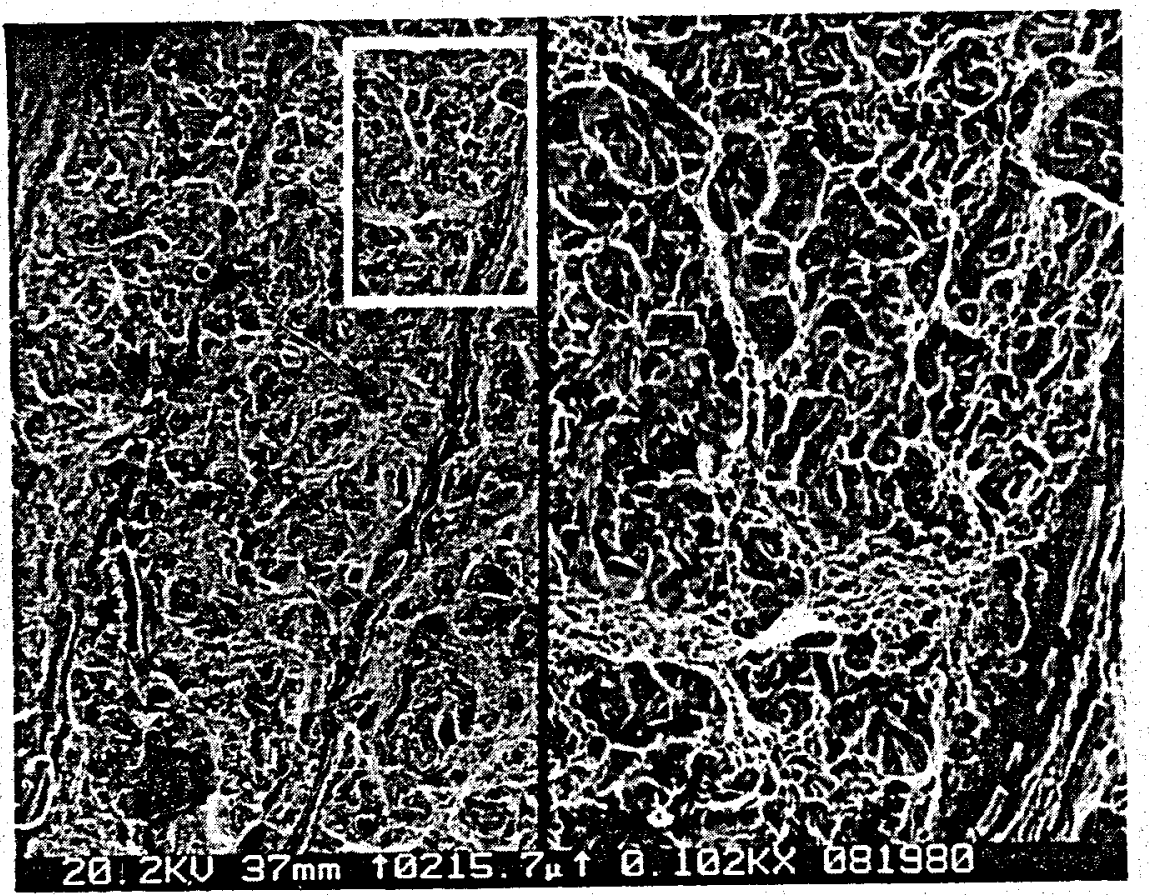

Figure B7. CBS 600 (Heat Treatment F). Room Temperature Static Test. Ductile Fracture (100-300X).

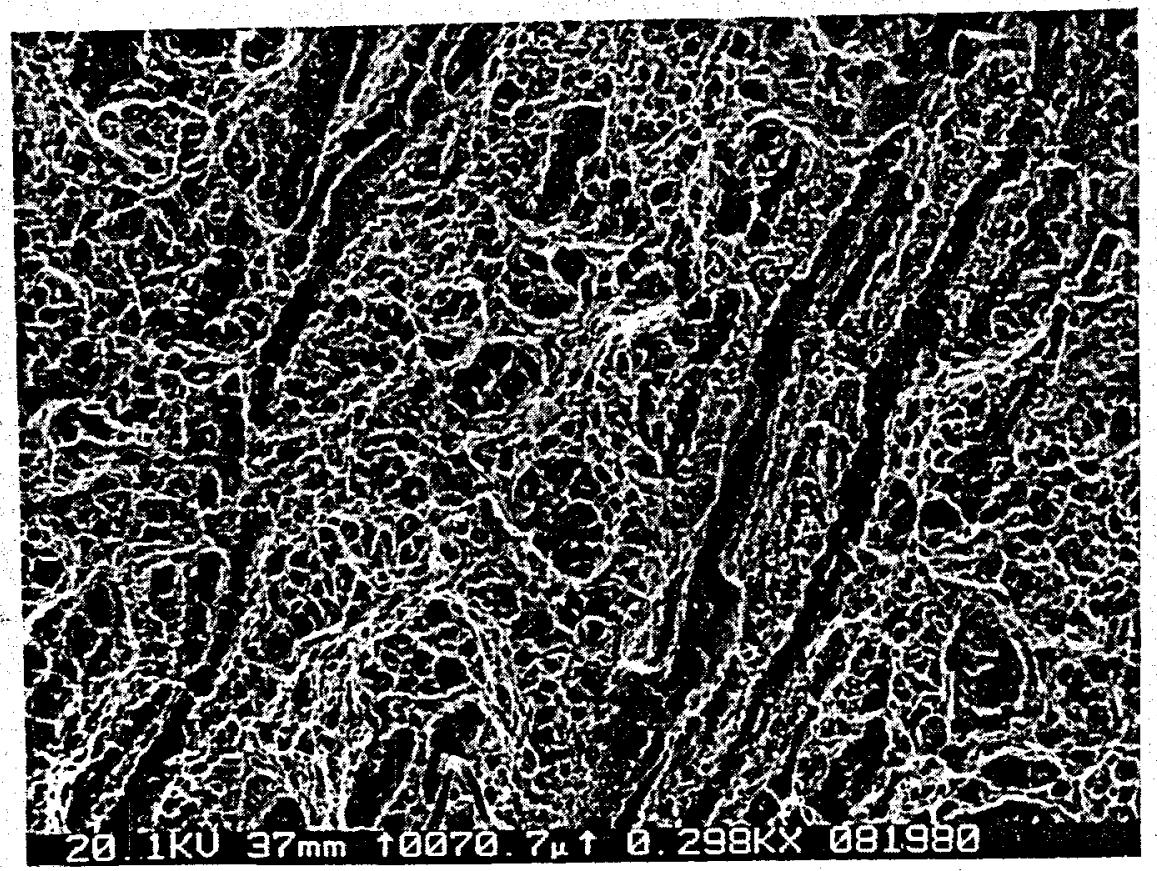

Figure B8. CBS 600 (Heat Treatment D). Room Temperature Static Test. Ductile Fracture (300X). 


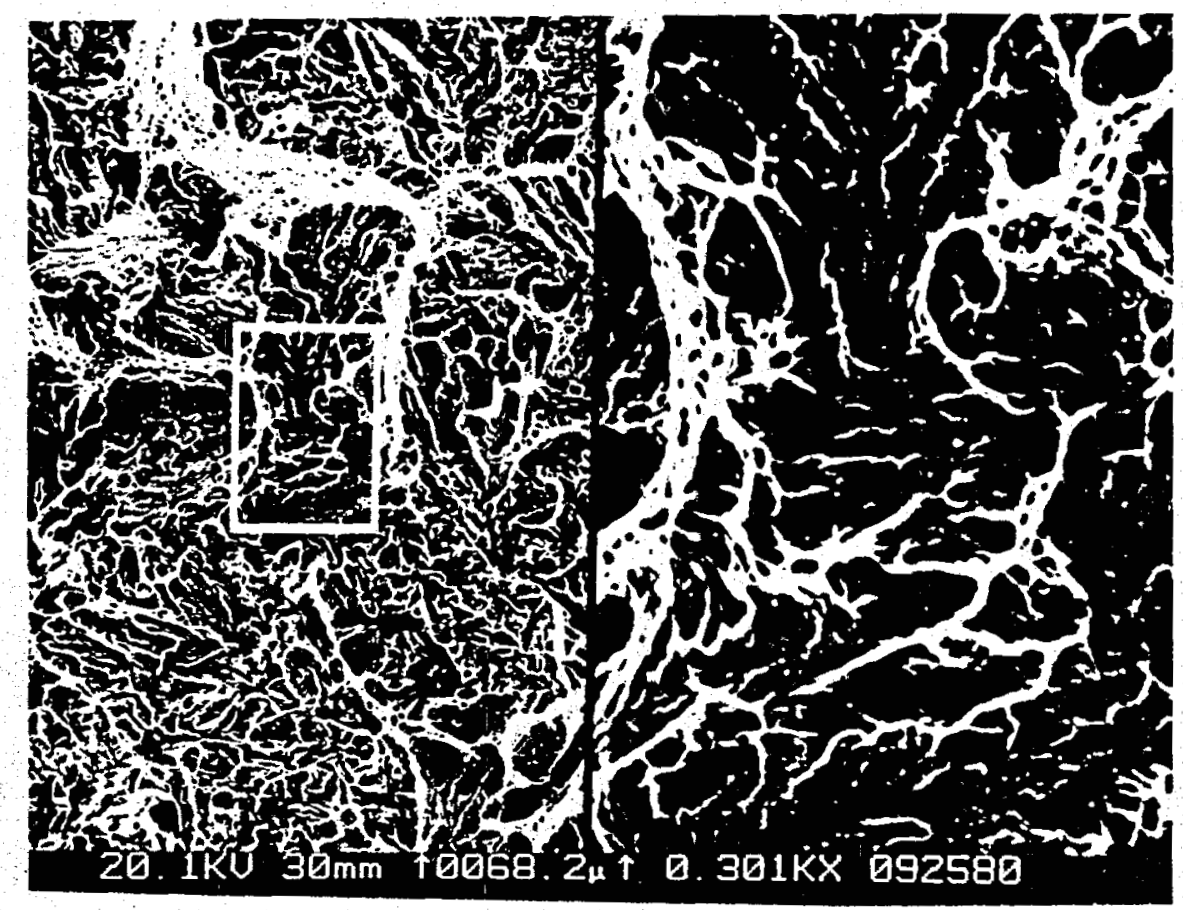

Figure B9. CBS 1000M (Heat Treatment I). Room Temperature Static Test. 25-75\% Brittle Cleavage (300-1200X).

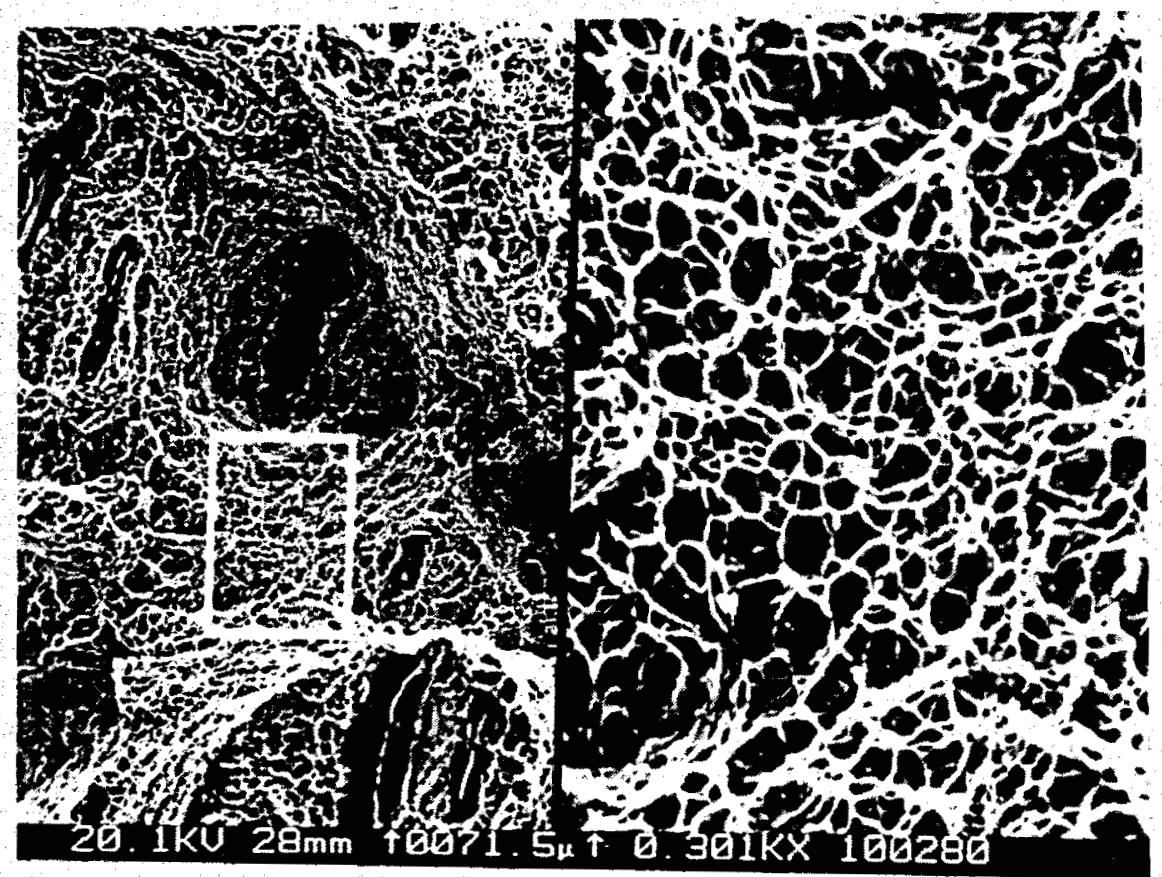

Figure B10. CBS 1000M (Heat Treatment I). $100^{\circ} \mathrm{C}$ Static Test. Ductile Fracture (300-1200X). 


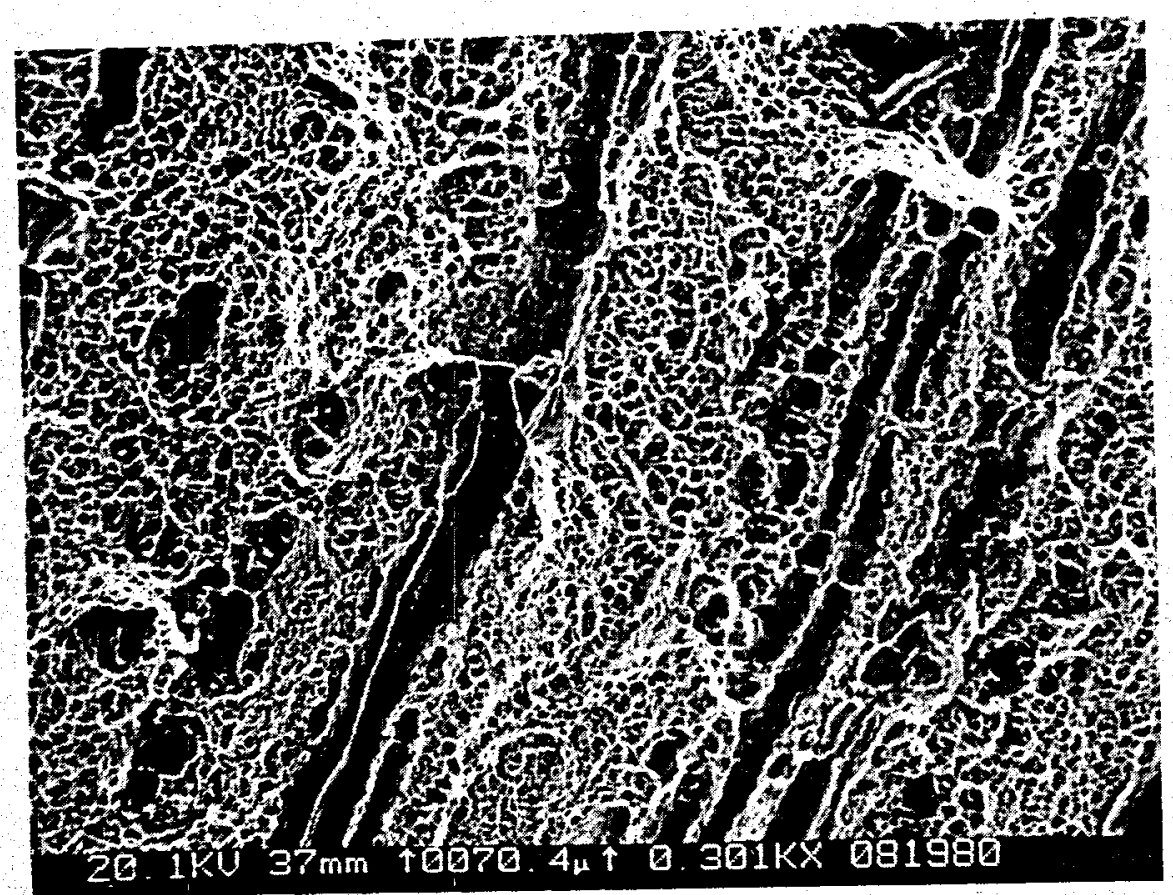

Figure B11. CBS 1000M (Heat Treatment I), $300^{\circ} \mathrm{C}$ Static Test. . Ductile Fracture (300X).

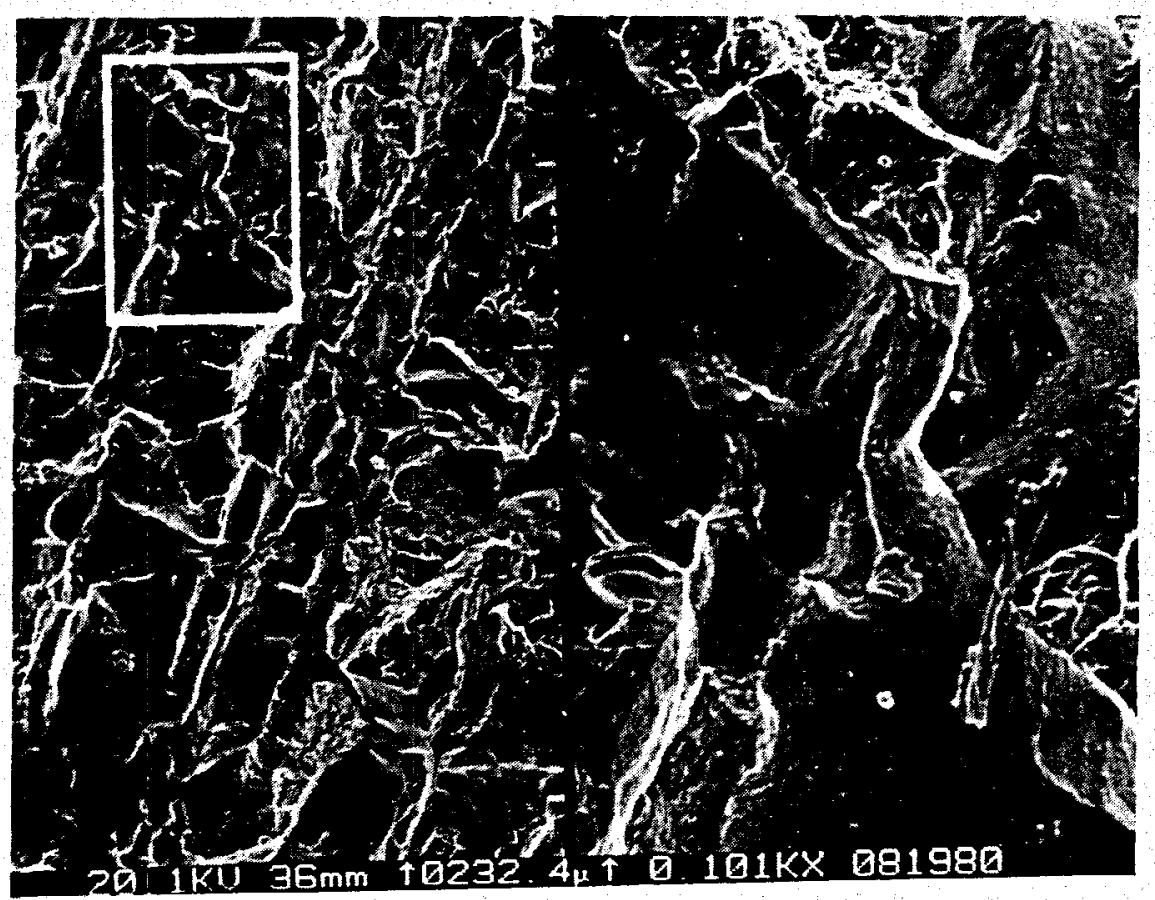

Figure. B12. CBS 1000M (Heat Treatment H). Room Temperature Static Test. Brittle Cleavage (300X). 


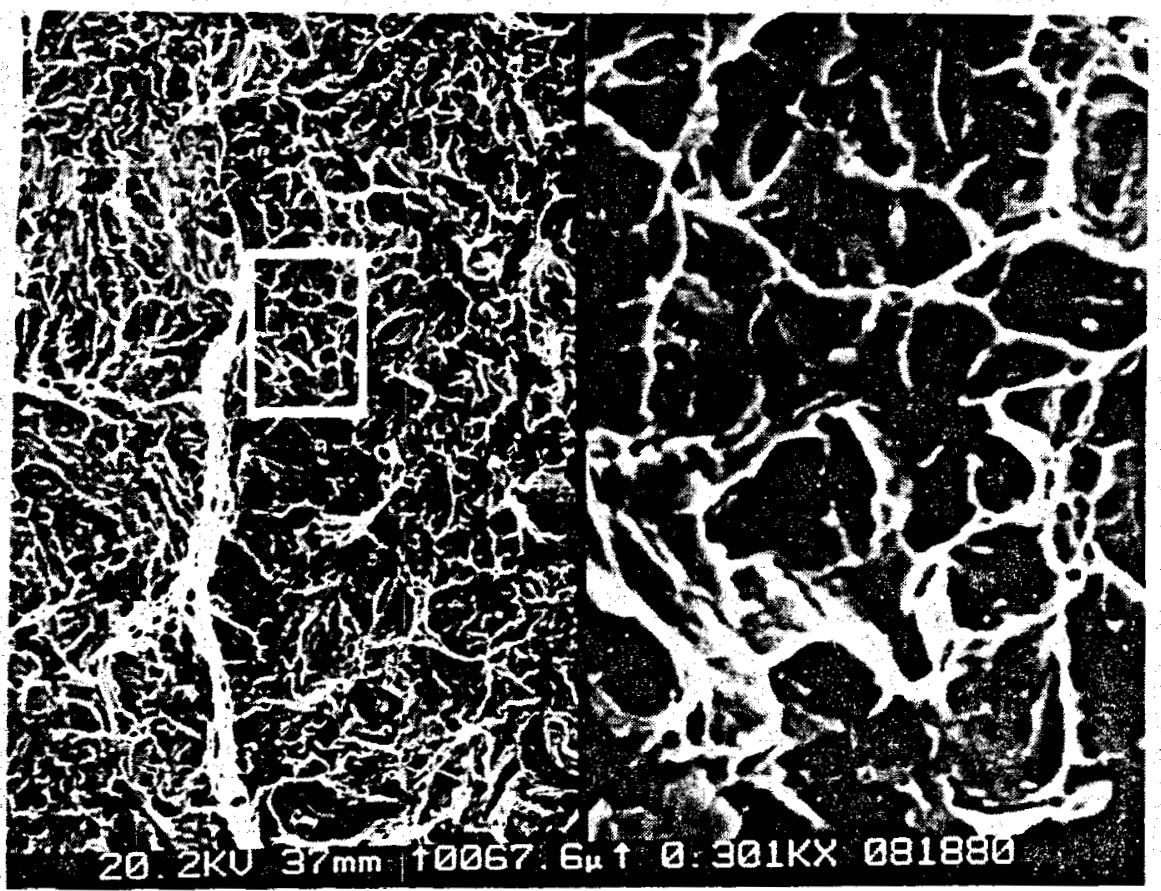

Figure B13. EX-00053. Room Temperature Static Test. Less than 25\% Brittle Cleavage (300-1500X).

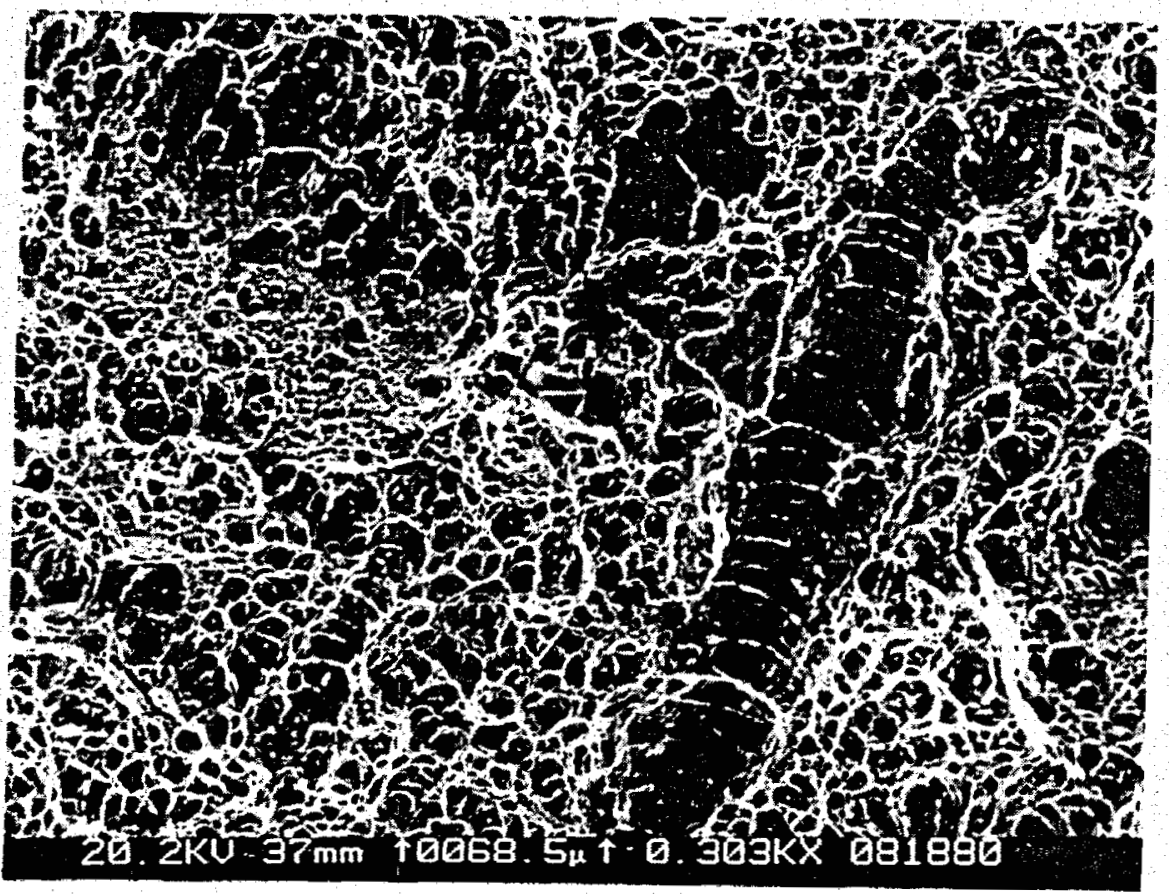

Figure B14. EX-00053. $100^{\circ} \mathrm{C}$ Static Test. Ductile Fracture (300X). 


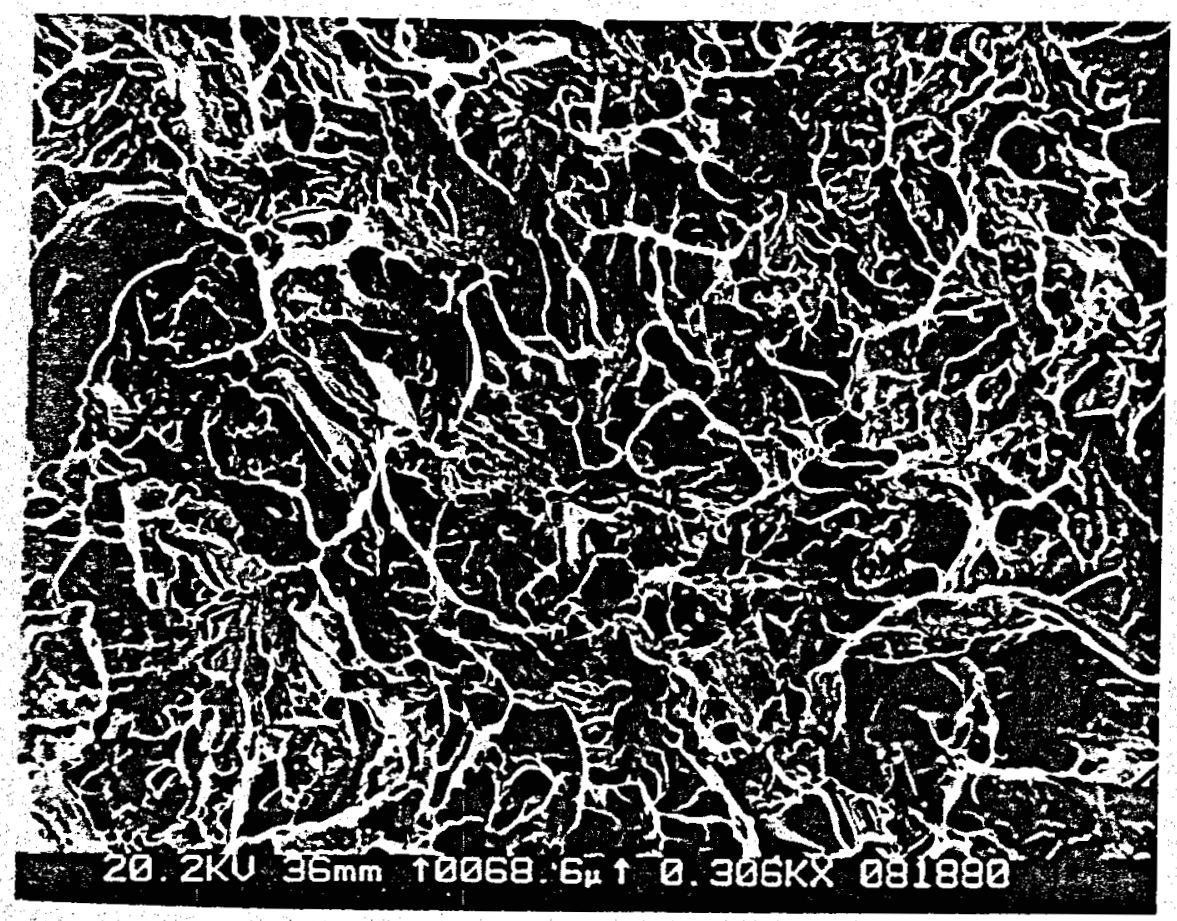

Figure B15. Vasco X2M. Room Temperature Static Test. Brittle Cleavage (300X).

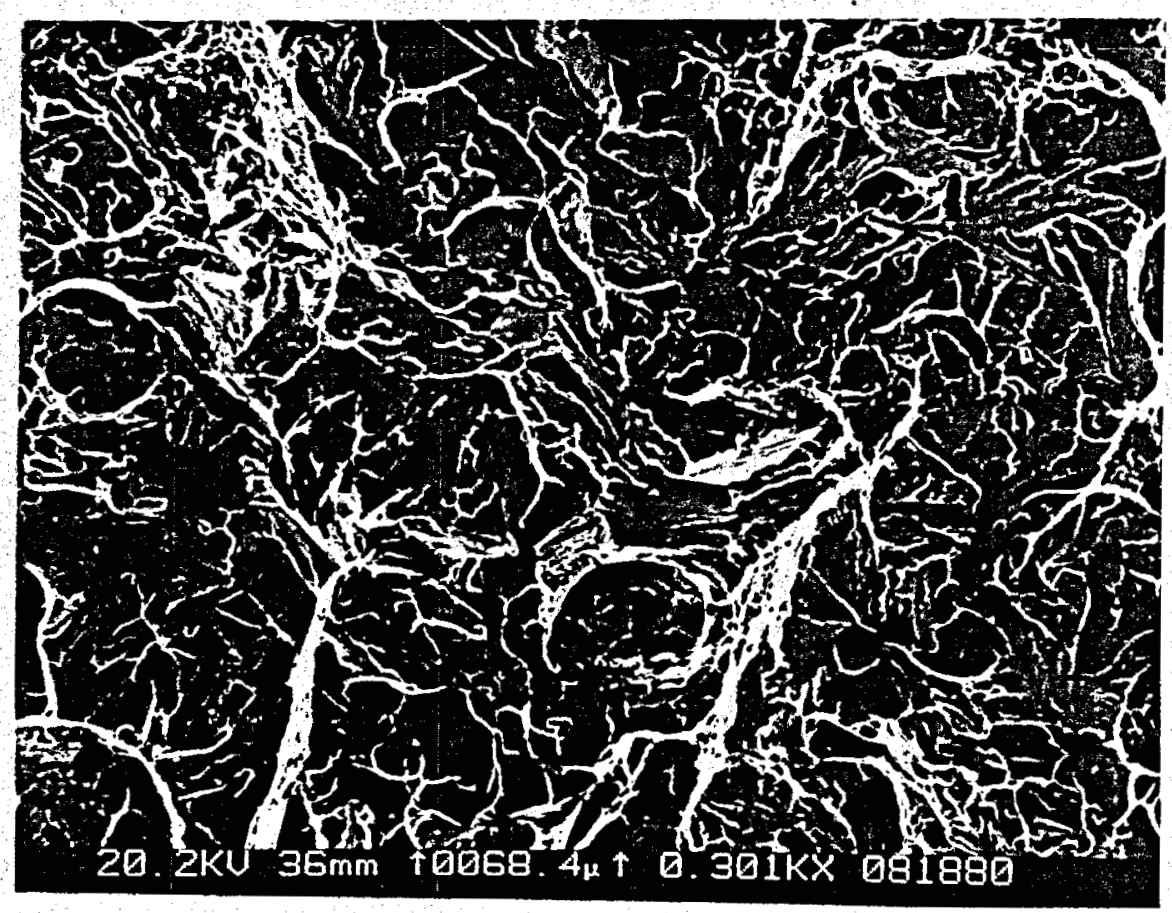

Figure B16. Vasco X2M. $100^{\circ} \mathrm{C}$ Static Test. Brittle Cleavage $(300 X)$. 


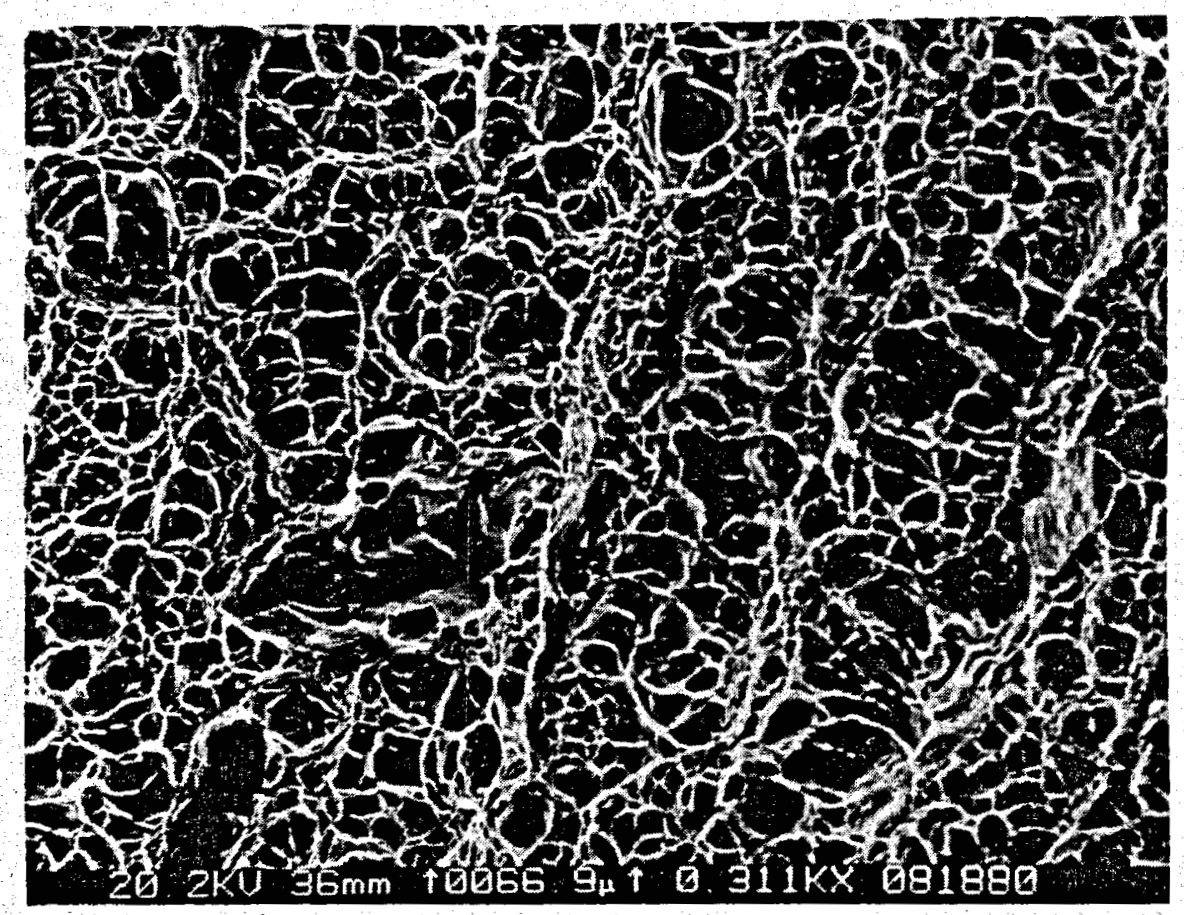

Figure B17. Vasco X2M. $200^{\circ} \mathrm{C}$ Static Test. Less than $25 \%$ Brittle Cleavage (300X).

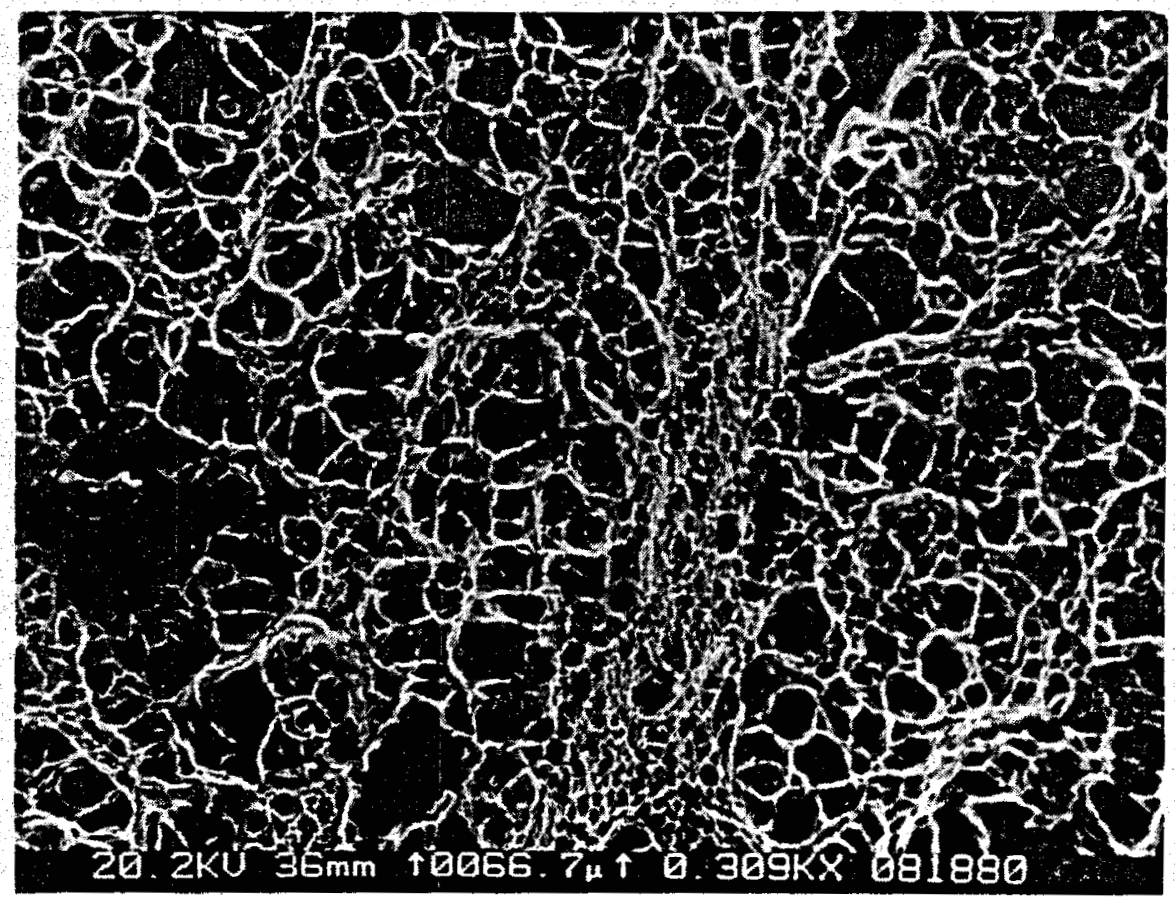

Figure B18. Vasco $\mathrm{X} 2 \mathrm{M}$. $300^{\circ} \mathrm{C}$ Static Test. Ductile Fracture $(300 \mathrm{X})$. 


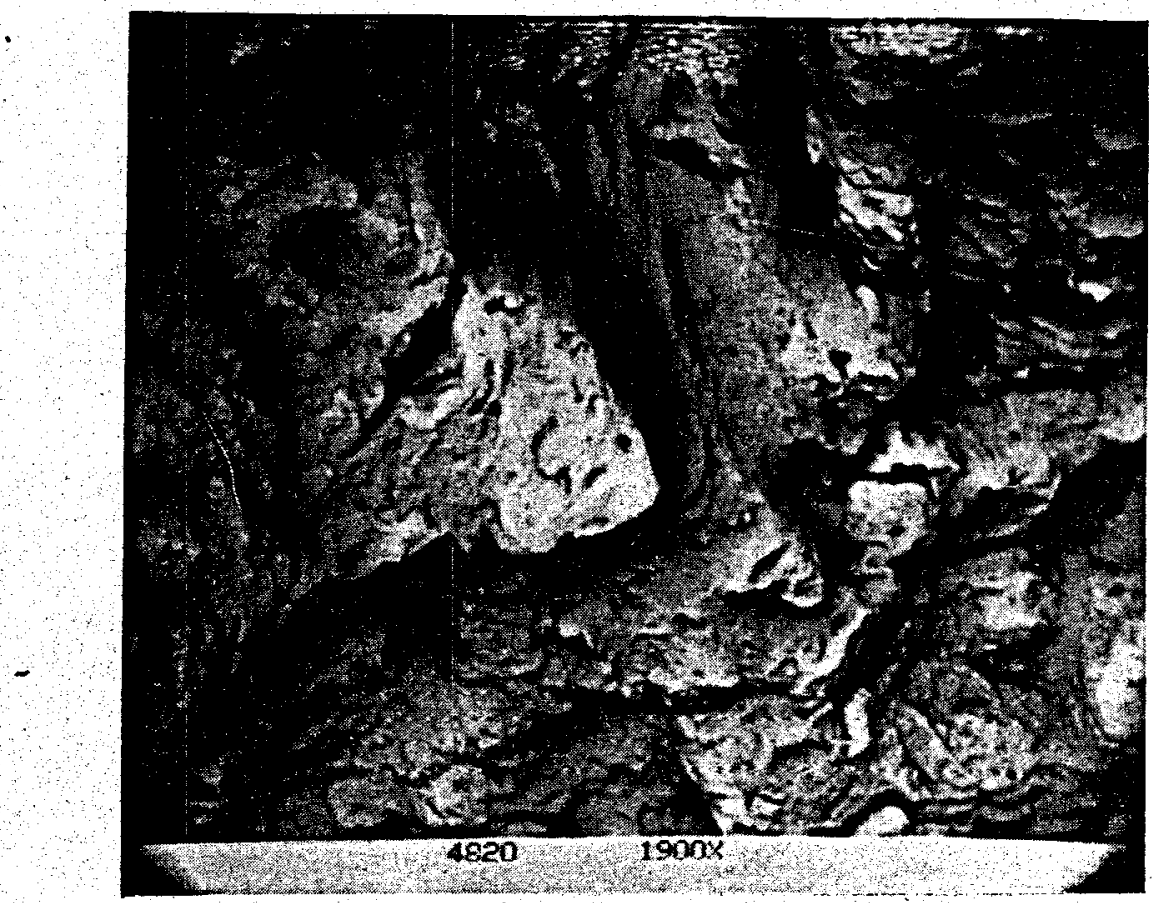

Figure B19. AISI 4820. Room Temperature Fatigue Test (1900X).

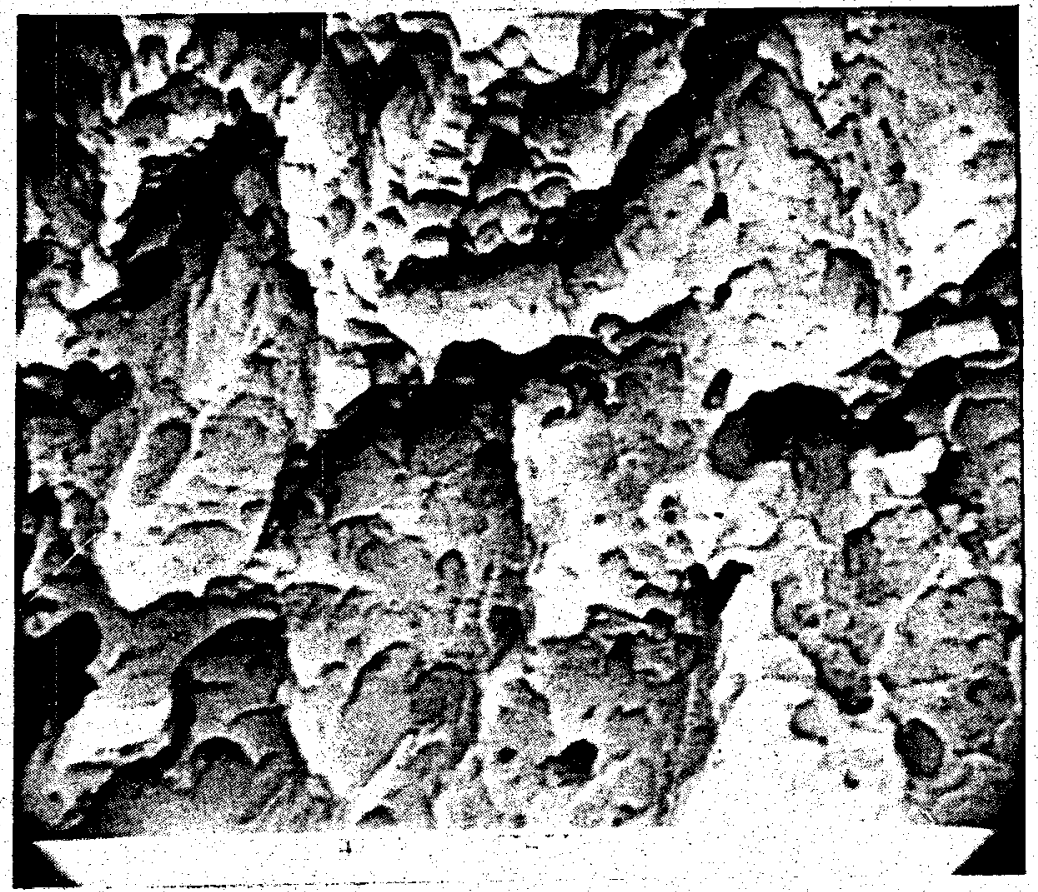

Figure B20. AISI 4820. Room Temperature Static Test (1900X). 


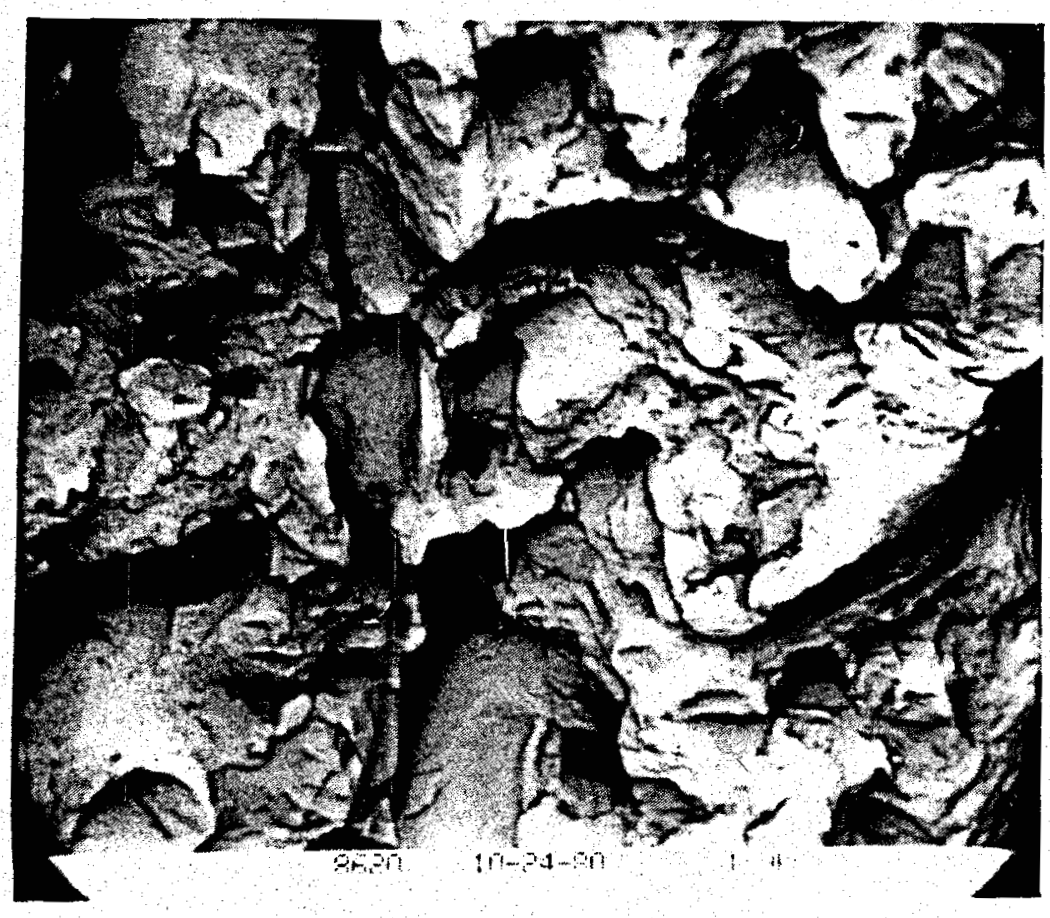

Figure B21. AISI 8620. Room Temperature Fatigue Test (1900X).

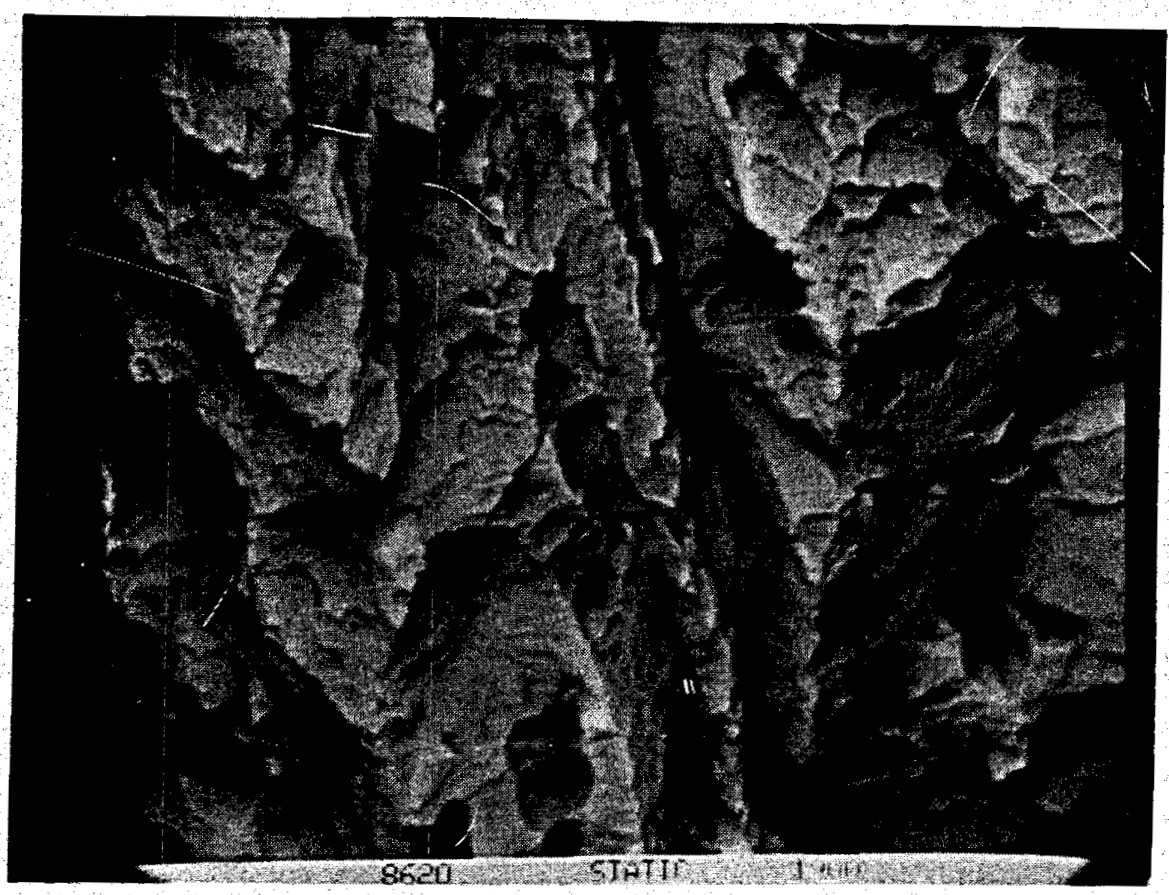

Figure B22. AISI 8620. Room Temperature Static Test (1900X). 


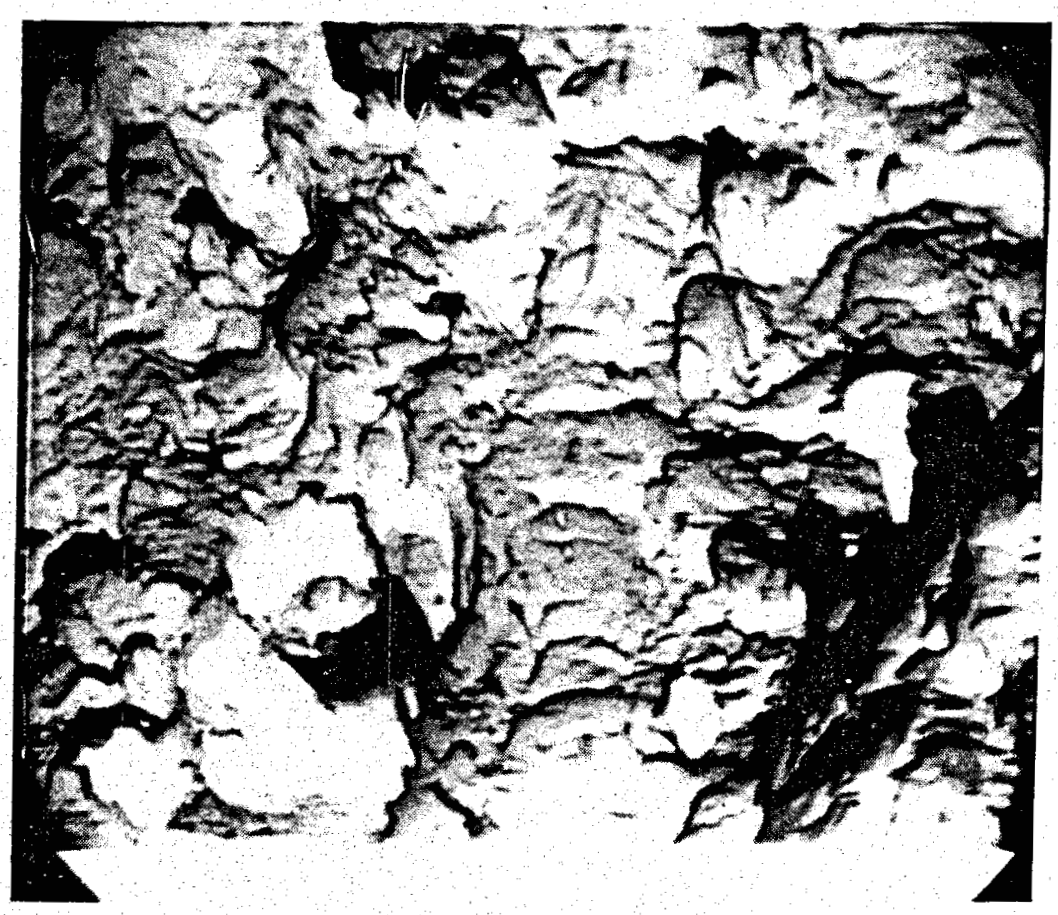

Figure B23. AISI 9315. Room Temperature Fatigue Test (1750X).

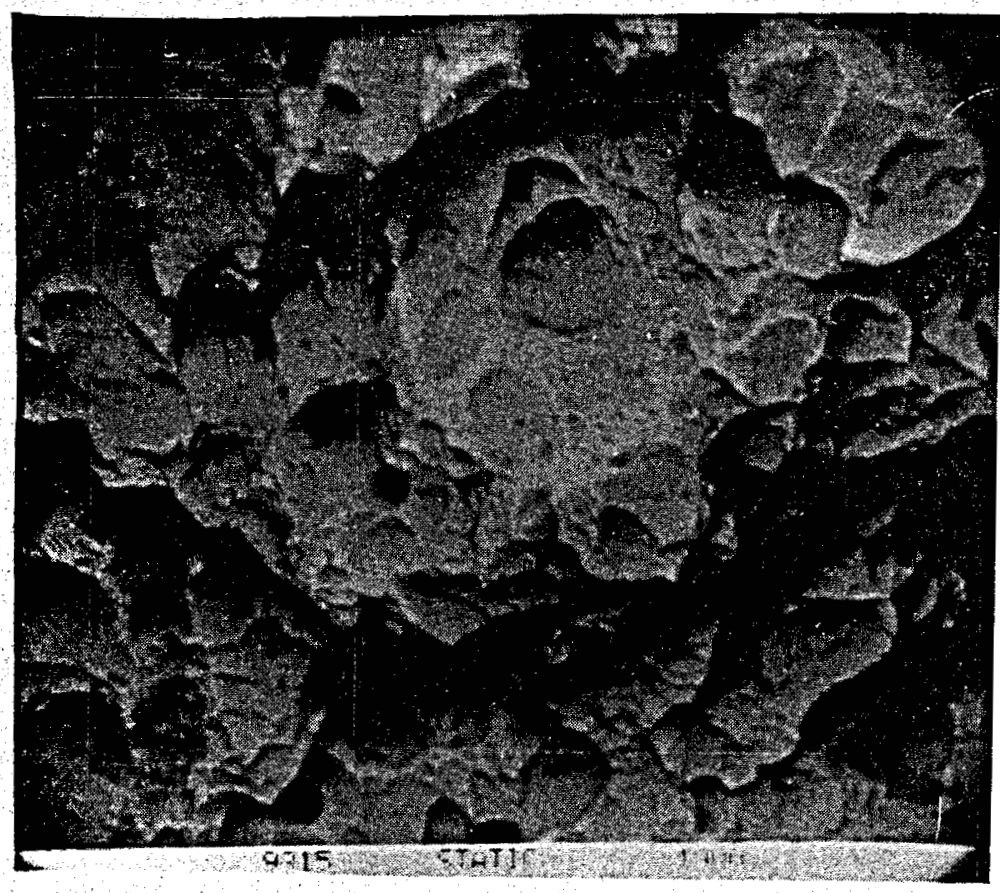

Figure B24. AISI 9315. Room Temperature Static Test (1900X). 


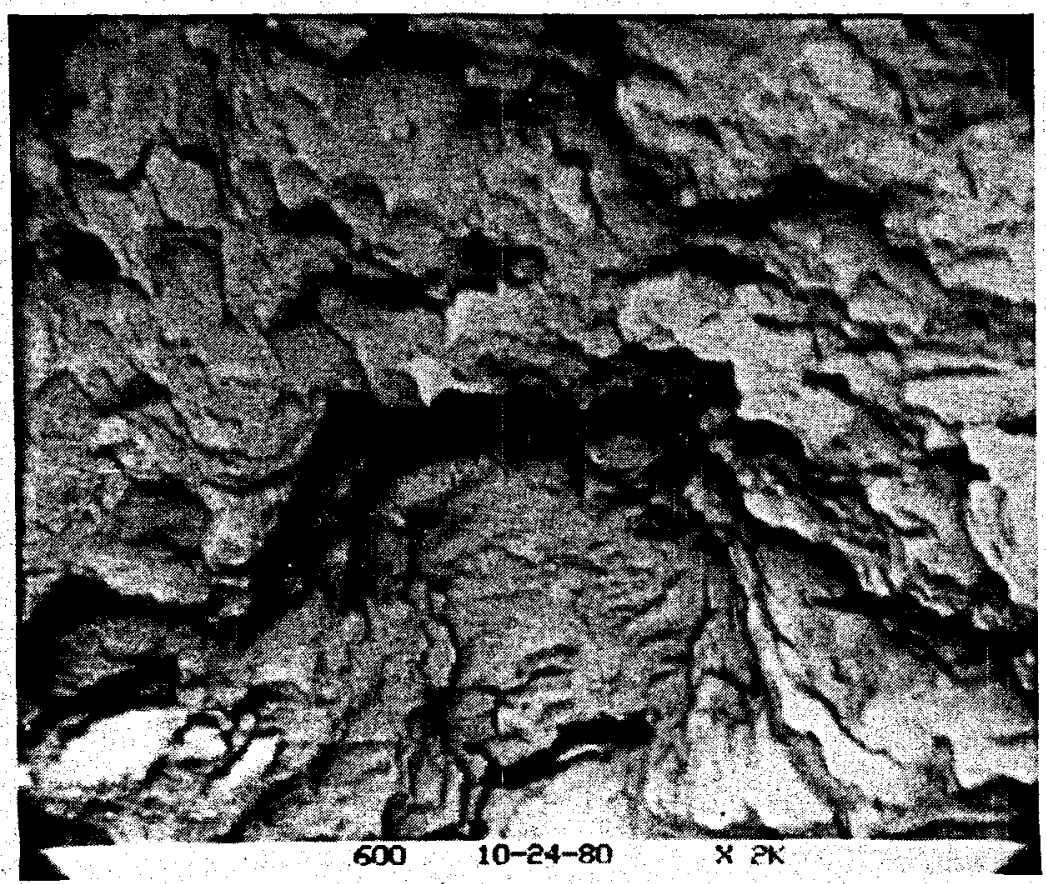

Figure B25. CBS 600 (Heat Treatment D), $300^{\circ} \mathrm{C}$ Fatigue Test (2000X).

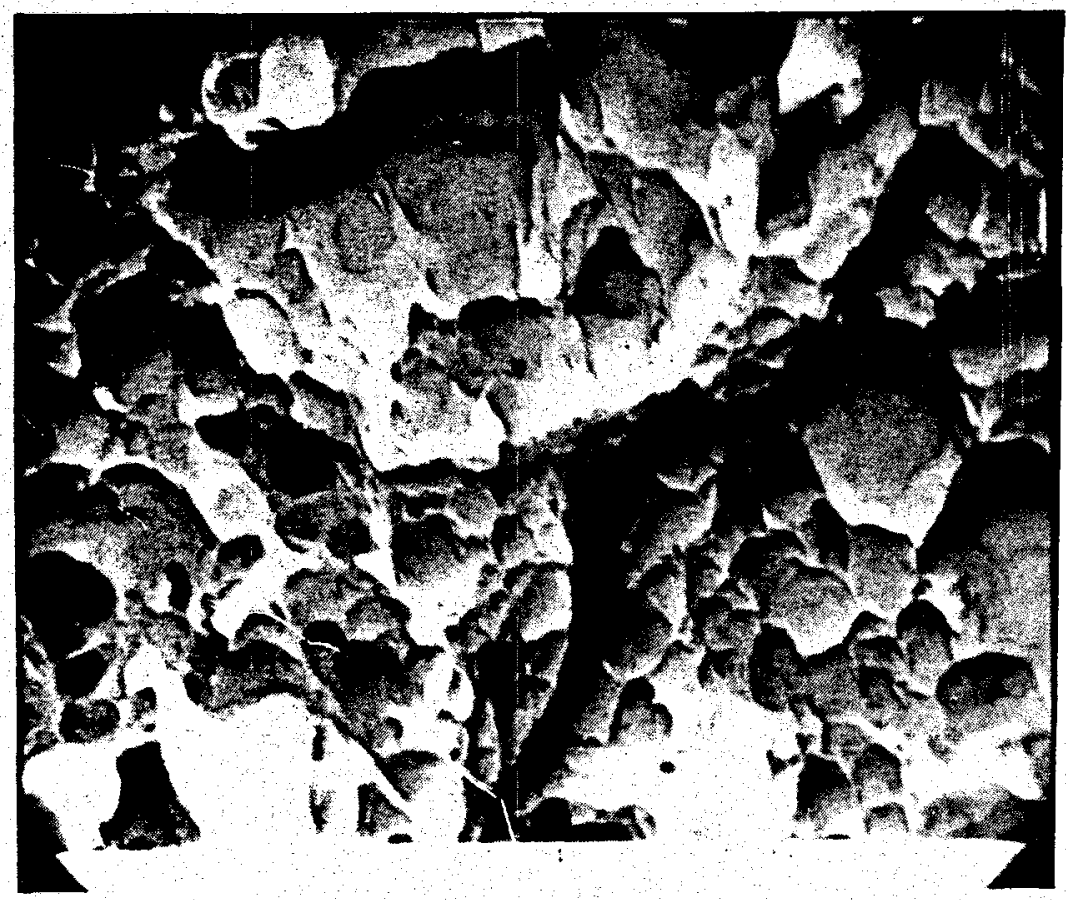

Figure B26. CBS 600 (Heat Treatment D). $300^{\circ} \mathrm{C}$ Static Test (1850X). 


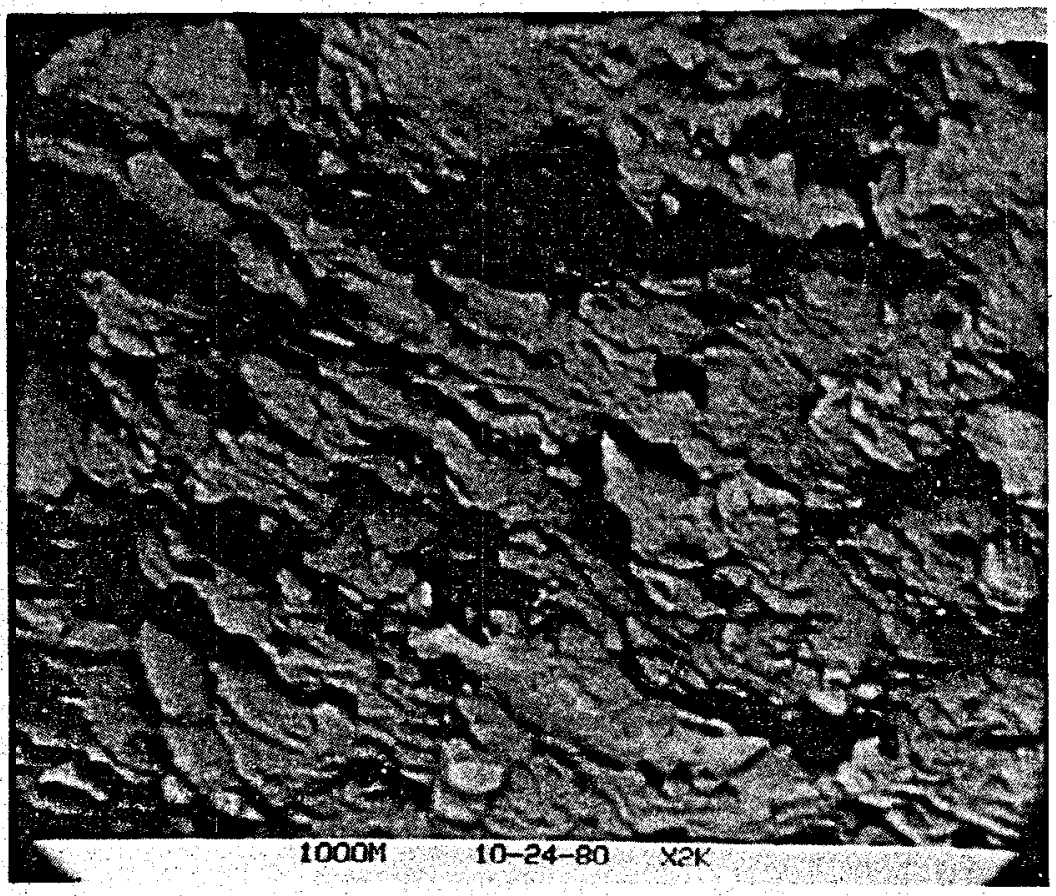

Figure B27. CBS 1000M (Heat Treatment G), $300^{\circ} \mathrm{C}$ Fatigue Test (2000X).

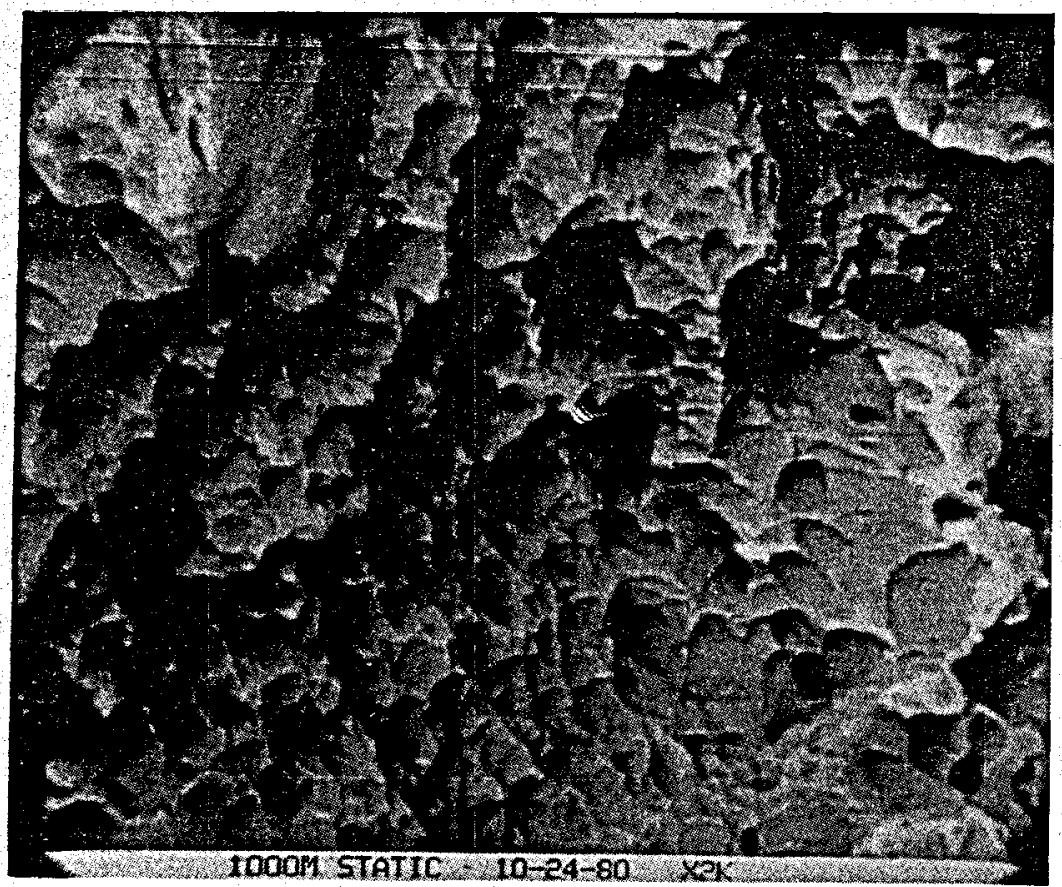

Figure B28. CBS $1000 \mathrm{M}$ (Heat Treatment G). $300^{\circ} \mathrm{C}$ Static Test (2000X). 


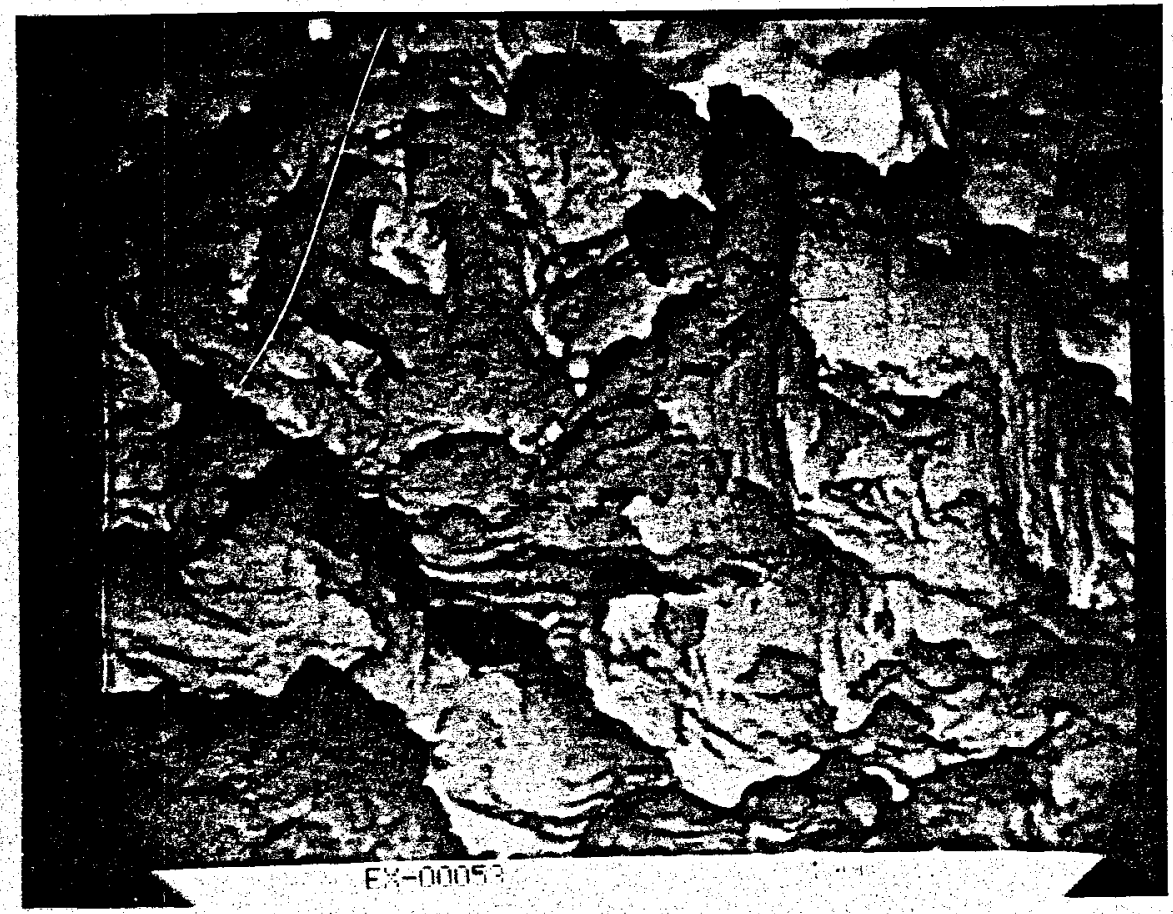

Figure B29. EX-00053. $300^{\circ} \mathrm{C}$ Fatigue Test (1900X).

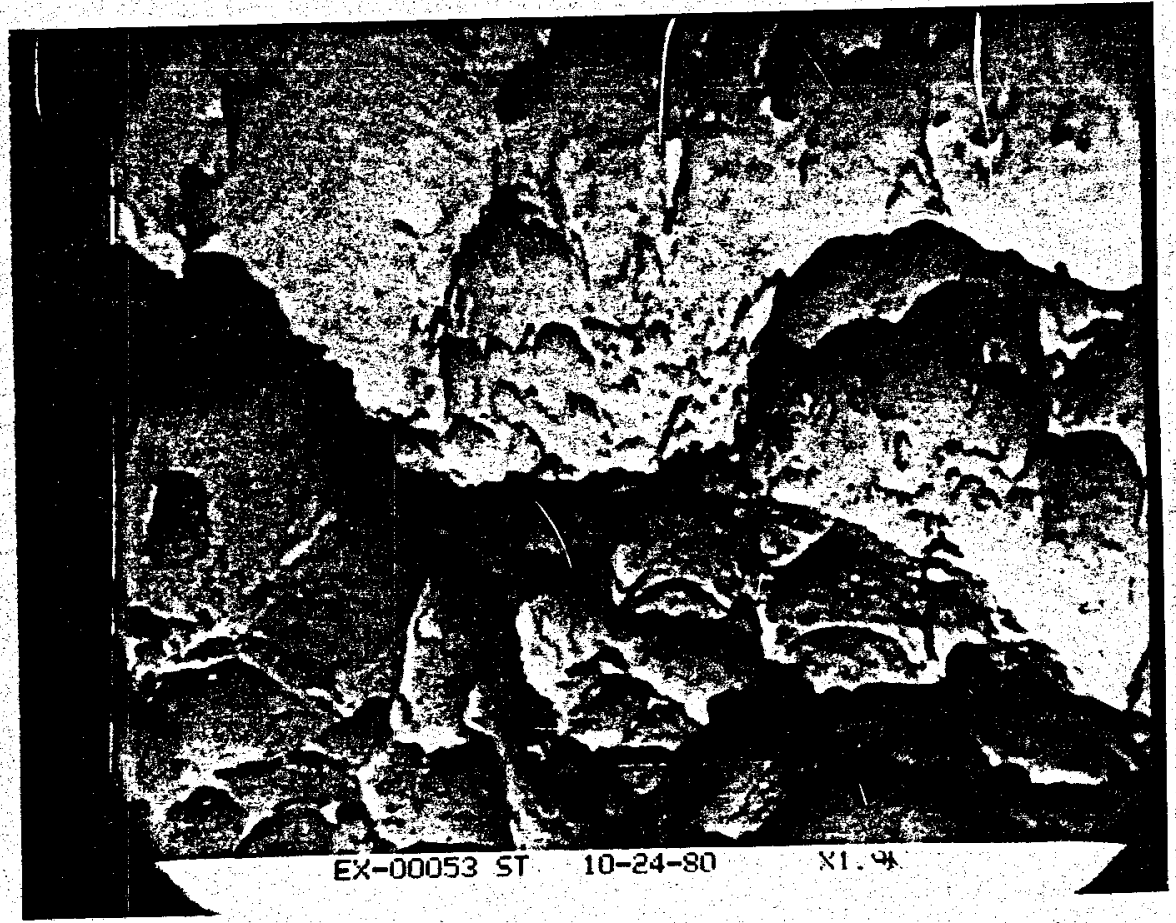

Figure B30. EX-00053. $300^{\circ} \mathrm{C}$ static Test (1900X). 


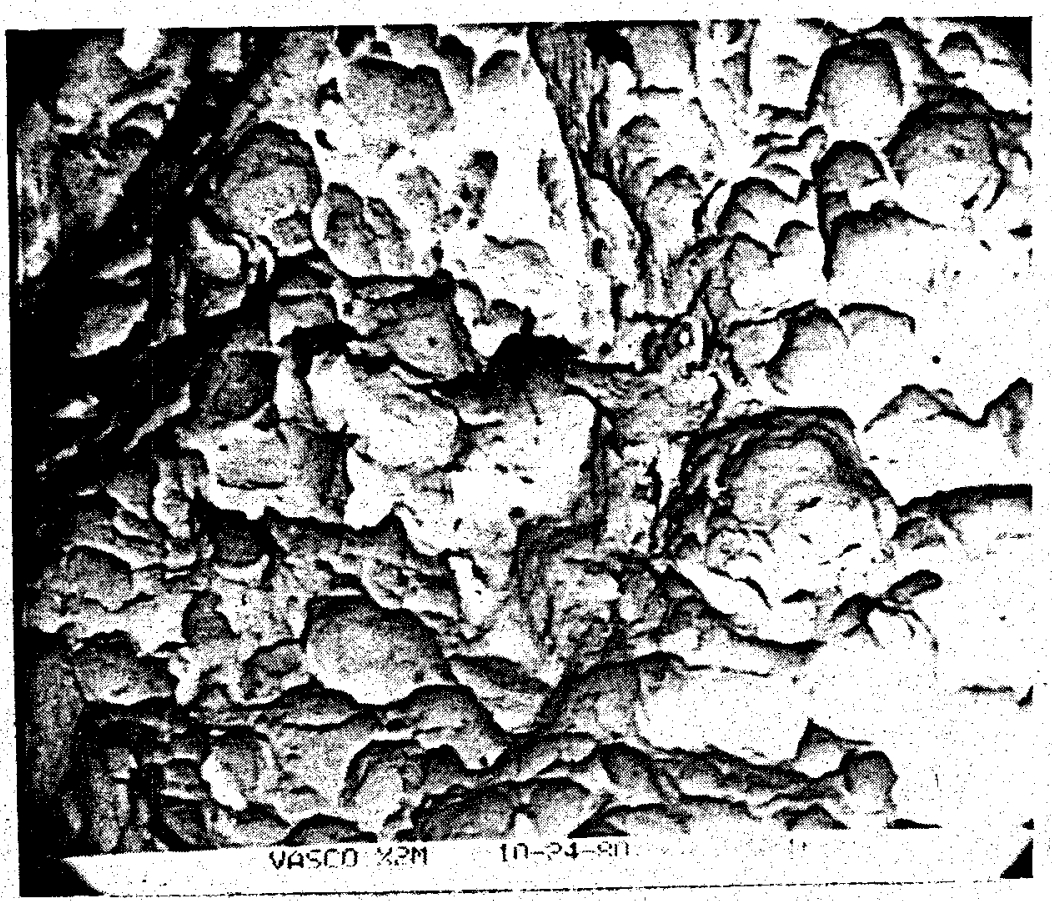

Figure B31. Vasco X2M. $300^{\circ} \mathrm{C}$ Fatigue Test (1000X).

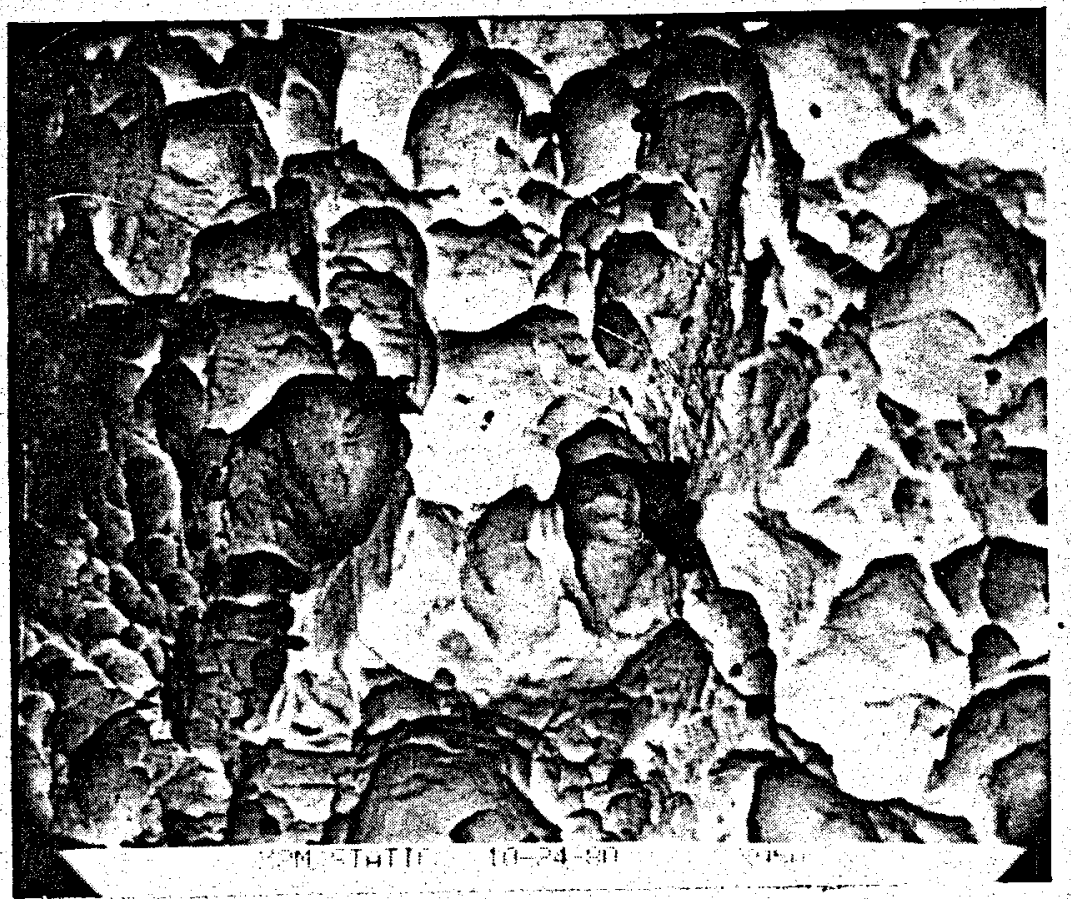

Figure B32. Vasco X2M. $300^{\circ} \mathrm{C}$ static Test (950X). 



\section{CBS Steels}

Timken Company

3901 MacArthur Boulevard

Suite 104

Newport Beach, California 92660

(714) 955-1700

Paul Garmus

Timken Research Center

1835 Deuber S.W.

Canton, Ohio 44706

(216) 497-2009

Chester F. Jatczak

\section{$\underline{E X-00053}$}

Carpenter Technology Corporation

Carpenter Steel Division

P.0. Box 662

Reading, Pennsylvania 19603

(215) 371-2000

Walter E. Burd

$\underline{\text { Vasco X2M }}$

Teledyne/Vasco

P.0. Box 151

Latrobe, Pennsylvania 15650

(412) $537-5551$

Richard J. Henry 